\title{
An Aerial-Photographic Assessment of Reenacted Handcart Treks on a Section of the Mormon Pioneer National Historic Trail, Fremont County, Wyoming
}

Prepared in cooperation with Bureau of Land Management
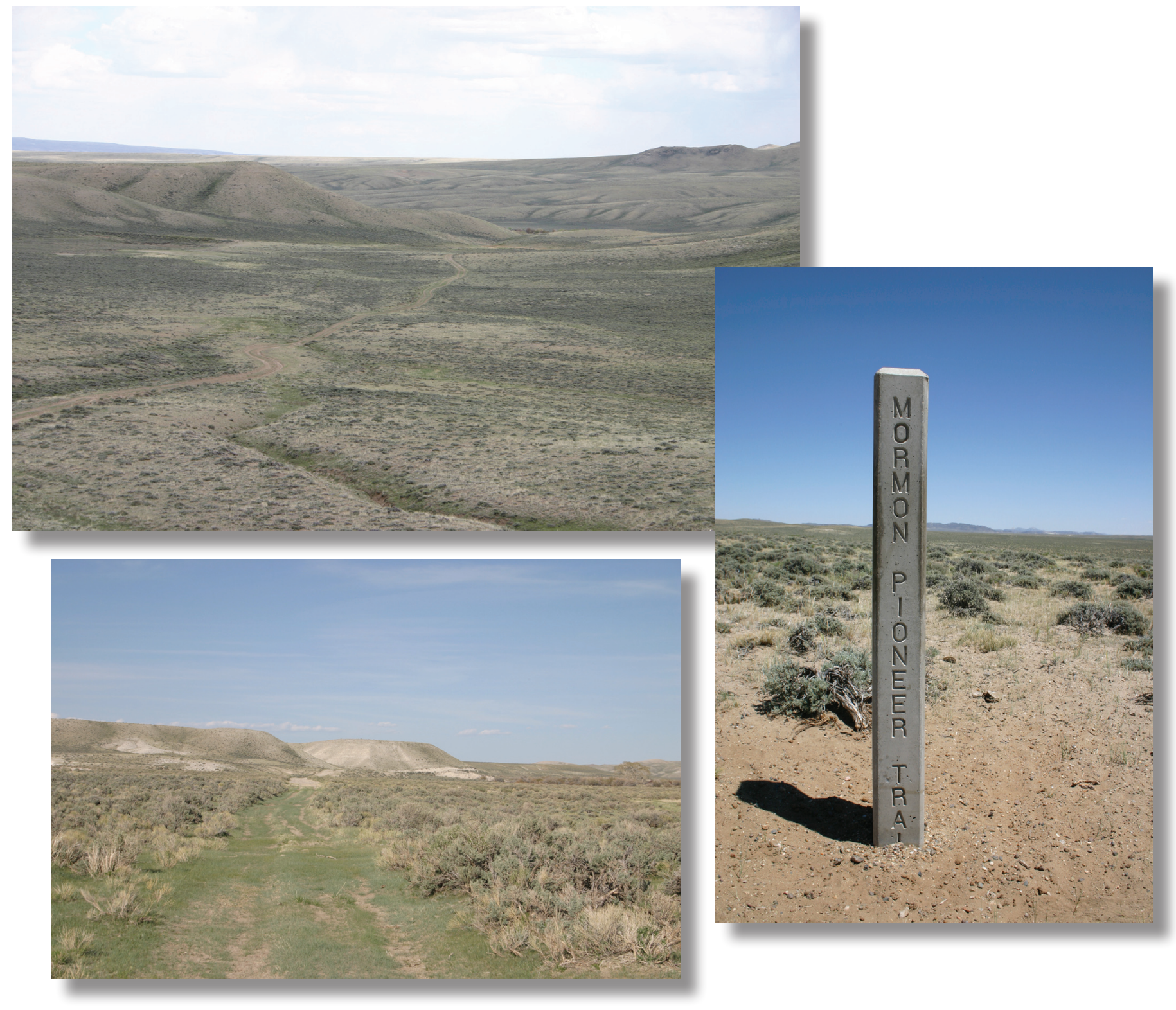

Scientific Investigations Report 2008-5115 
Cover photographs: Scenes along the historic Mormon Pioneer Trail between Sixth Crossing and Rock Creek Hollow, Fremont County, Wyoming. For use or reproduction permission please contact: Cameron L. Aldridge, Fort Collins Science Center, Fort Collins, C0, 80526 E-mail cameron_aldridge@usgs.gov. 970-226-9433. 


\section{An Aerial-Photographic Assessment of Reenacted Handcart Treks on a Section of the Mormon Pioneer National Historic Trail, Fremont County, Wyoming}

By Robert R. McDougal, Robert G. Waltermire, Cameron L. Aldridge, Stephen S. Germaine, Scott E. Nielsen, Charlene C. Nielsen, Leanne Hanson, and Zachary H. Bowen

Prepared in cooperation with Bureau of Land Management

Scientific Investigations Report 2008-5115 


\title{
U.S. Department of the Interior DIRK KEMPTHORNE, Secretary
}

\author{
U.S. Geological Survey \\ Mark D. Myers, Director
}

\section{U.S. Geological Survey, Reston, Virginia: 2008}

For product and ordering information:

World Wide Web: http://www.usgs.gov/pubprod

Telephone: 1-888-ASK-USGS

For more information on the USGS - the Federal source for science about the Earth, its natural and living resources, natural hazards, and the environment:

World Wide Web: http://www.usgs.gov

Telephone: 1-888-ASK-USGS

Any use of trade, product, or firm names is for descriptive purposes only and does not imply endorsement by the U.S. Government.

Although this report is in the public domain, permission must be secured from the individual copyright owners to reproduce any copyrighted materials contained within this report.

Suggested citation:

McDougal, R.R., Waltermire, R.G., Aldridge, C.L., Germaine, S.S., Nielsen, S.E., Nielsen, C.C., Hanson, Leanne, and Bowen, Z.H., 2008, An Aerial-Photographic Assessment of Reenacted Handcart Treks on a Section of the Mormon Pioneer National Historic Trail, Fremont County, Wyoming: U.S. Geological Survey Scientific Investigations Report $2008-5115,70 \mathrm{p}$. 


\section{Contents}

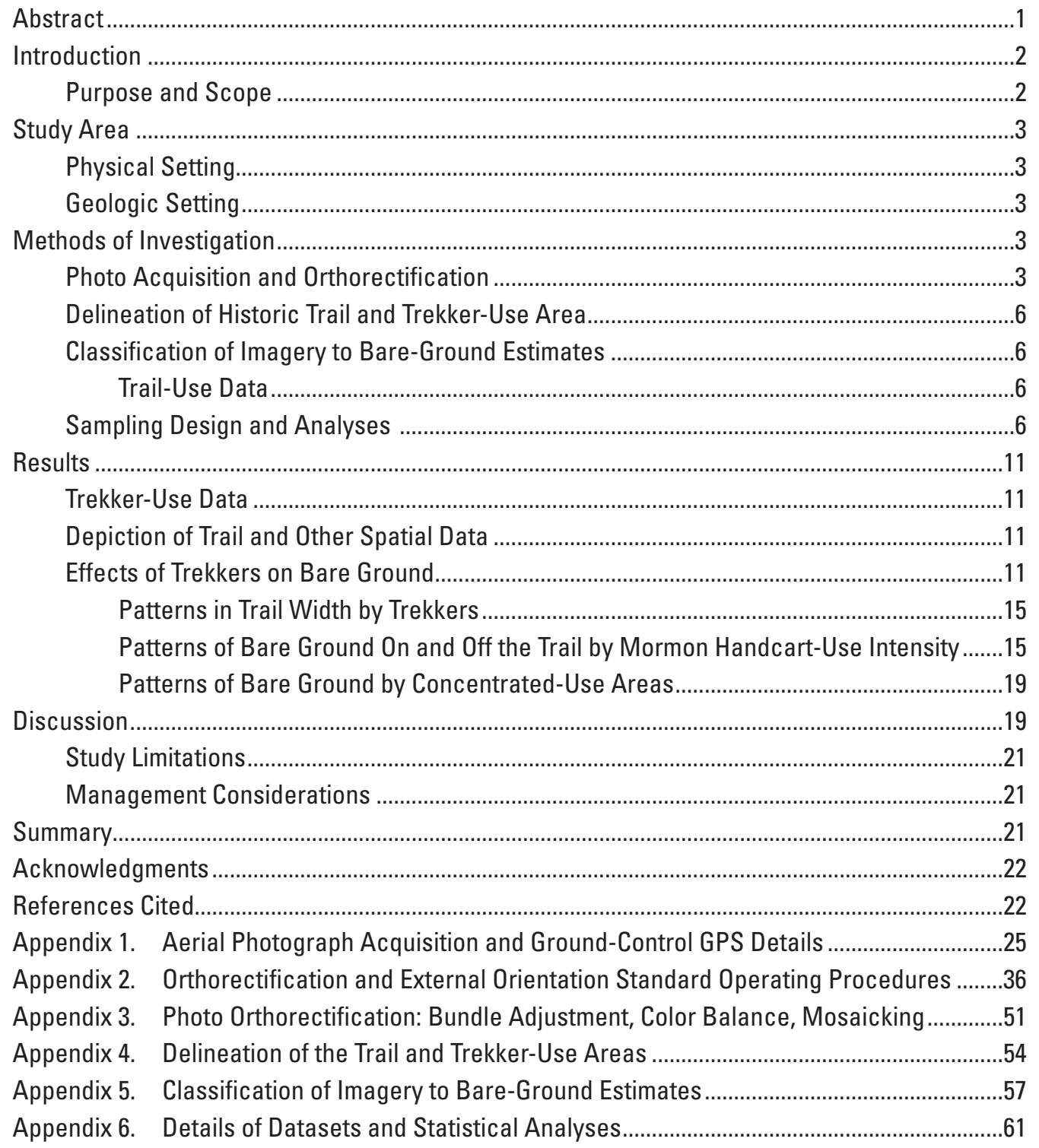




\section{Figures}

1. Map showing the Mormon Pioneer National Historic Trail study area, which extends 40 kilometers west from Sixth Crossing to Rock

Creek Hollow, Fremont County, Wyoming.

2. Map showing the Mormon Pioneer National Historic Trail alignment and Mormon handcart-trekking route between Sixth Crossing and Rock Creek Hollow, Fremont County, Wyoming.

3. An example of the transition from color aerial photographs (top row) to ERDAS (Earth Resources Data Analysis System) bare-ground class assignments

4-8. Maps showing:

4. (a) Half-day, one-day, and two-day trekker routes; and four levels of trekker-use intensity (b) along the Mormon Pioneer National Historic Trail between Sixth Crossing and Rock Creek Hollow, Fremont County, Wyoming, 2001 to 2006.

5. Example of perpendicular transect placement on aerial photographs of the Mormon Pioneer National Historic Trail between Sixth Crossing and Rock Creek Hollow, Fremont County, Wyoming.....

6. Motorized use on the Mormon Pioneer National Historic Trail between Sixth Crossing and Rock Creek Hollow, Fremont County, Wyoming... 10

7. Location of nine concentrated-use areas along the Mormon Pioneer National Historic Trail between Sixth Crossing and Rock Creek Hollow, Fremont County, Wyoming

8. Concentrated-use and random area polygons within which the percentage of bare ground versus vegetated ground were summed.

9-16. Graphs showing:

9. Cumulative number of Mormon trekkers in each of three use levels on the Mormon Pioneer National Historic Trail between Sixth Crossing and Rock Creek Hollow, Fremont County, Wyoming, 2001 to 2006.

10. Average trail-width values for five Mormon handcart-use intensity levels on the Mormon Pioneer National Historic Trail between Sixth Crossing and Rock Creek Hollow, Fremont County, Wyoming, 2006.

11. Average percentage of bare ground by category of Mormon handcart use and distance from trail center along the Mormon Pioneer National Historic Trail between Sixth Crossing and Rock Creek Hollow, Fremont County, Wyoming..

12. Percentage of bare ground among five Mormon handcart-use intensity levels and three distances from trail center between Sixth Crossing and Rock Creek Hollow, Mormon Pioneer National Historic Trail, Fremont County, Wyoming .

13. Difference in percentage of bare ground associated with Mormon handcart-use activity by distance from trail center between Sixth Crossing and Rock Creek Hollow, Mormon Pioneer National Historic Trail, Fremont County, Wyoming.

14. Predicted probability of bare ground plus the standard error (SE) based on handcart use level and distance from trail center, adjusted for soil and photo image effects between Sixth Crossing and Rock Creek Hollow, Mormon Pioneer National Historic Trail, Fremont County, Wyoming 
15. Predicted differences in percentage of bare ground between control and handcart-use sites at trail center and 1 meter distance from trail center, after accounting for soil and photo image variation between Sixth Crossing and Rock Creek Hollow, Mormon Pioneer National Historic Trail,

Fremont County, Wyoming

16. Percentage of bare ground present at concentrated-use and random sites along the Mormon Pioneer National Historic Trail between Sixth Crossing and Rock Creek Hollow, Fremont County, Wyoming.

\section{Tables}

1. Estimated number of handcart users along three distinct reenactment routes.

2. Average percentage of bare ground in five Mormon handcart-use intensity levels and three distance classes from trail center along the Mormon Pioneer National Historic Trail between Sixth Crossing and Rock Creek Hollow,

Fremont County, Wyoming

3. Logistic regression results describing the probability of being classified bare ground along the Mormon Pioneer National Historic Trail at two on-trail distances from trail center ( 0 and 1 meters) between Sixth Crossing and Rock Creek Hollow, Mormon Pioneer National Historic Trail,

Fremont County, Wyoming 



\title{
An Aerial-Photographic Assessment of Reenacted Handcart Treks on a Section of the Mormon Pioneer National Historic Trail, Fremont County, Wyoming
}

\author{
By Robert R. McDougal, ${ }^{1}$ Robert G. Waltermire, ${ }^{2}$ Cameron L. Aldridge, ${ }^{3}$ Stephen S. Germaine, ${ }^{2}$ \\ Scott E. Nielsen, ${ }^{4}$ Charlene C. Nielsen, ${ }^{4}$ Leanne Hanson, ${ }^{2}$ and Zachary H. Bowen ${ }^{2}$
}

\section{Abstract}

Reenactments of historical pioneer emigrations have increased in popularity since the celebration of these events during the United States bicentennial in 1976. From 1999 to 2006, approximately 70,000 Mormon trekkers traveled the Mormon Pioneer National Historic Trail (hereinafter referred to as the Trail) segment between Sixth Crossing and Rock Creek Hollow in Fremont County, Wyoming. Recent elevated levels of use have raised concerns over potential recreationrelated damage to this particularly scenic segment of the Trail.

In 2006, the Bureau of Land Management (BLM) contracted the U.S. Geological Survey (USGS) to conduct an aerial-photographic assessment of the condition of the Trail between Sixth Crossing and Rock Creek Hollow. Specifically, the USGS was to assess trail conditions for this segment as influenced by handcart use (low, medium, and high intensity of use) and concentrated activities associated with trekking (toilet, rest, and camp sites).

In June 2006, high-resolution (10 centimeter) color aerial photography was collected for the 40-kilometer trail segment between Sixth Crossing and Rock Creek Hollow. Annual numbers of trekkers for three different handcart-use levels were estimated for Trail segments based on the BLM Lander Field Office records. The Trail centerline, trail edges, and boundaries of concentrated use (toilet and rest) areas were digitized in a Geographic Information System (GIS) based on aerial imagery, and a bare-ground classification was conducted using spectral imaging software. To assess the effects of

${ }^{1}$ U.S. Geological Survey, Denver, CO 80225.

${ }^{2}$ U.S. Geological Survey, Fort Collins Science Center, Fort Collins, CO 80526.

${ }^{3}$ Natural Resource Ecology Laboratory, Colorado State University, and U.S. Geological Survey, Fort Collins Science Center, Fort Collins, CO 80526.

${ }^{4}$ Arctic Slope Regional Corporation Management Services, contracted to: U.S. Geological Survey, Fort Collins Science Center, Fort Collins, CO 80526. handcarts, the relation between trail width and on-trail patterns in classified bare ground to three levels of handcart use was modeled, while accounting for local confounding factors including soil type and topographic attributes. The amount of bare ground at concentrated use areas also was compared to random trailside (control) sites to assess the magnitude of vegetative disturbance.

By using interpretation of the digital air-photo image, the precision and accuracy of the Trail alignment between Sixth crossing and Rock Creek Hollow were notably improved. No visible effects of handcart trekking on trail width were noted, and there were only minimal increases in bare ground on trails due to handcart trekking. At most, it appears that handcart activities increase the total amount of bare soil by approximately 9 percent after controlling for confounding factors. No obvious thresholds among levels (low, medium, and high) of handcart use were apparent. Although handcart activity only marginally increased amounts of bare ground on the Trail, motor vehicle traffic appears to have historically controlled and continues to affect trail width and vegetative loss. The results of this study indicate a 42 - to 60 -percent increase in bare ground relative to the average incidence of bare ground present off the trail $(\geq 2$ meters from trail centerline $\bar{x}=15.1$ percent bare ground). Finally, seven of nine concentrated use areas had substantially more bare ground $(\bar{x}=45.0$ percent $)$ than random sites $(\bar{x}=20.7$ percent $)$. The nine concentrated use areas ranged from 46 to 7,237 square meters in area.

Based on these results, there are identifiable management considerations. Toilet and rest sites need to be carefully located relative to where sensitive vegetation or soils occur. The analyses presented here indicate that limiting motorized vehicle use needs to be a priority over that of adjusting the number of trekkers. Additionally, monitoring of the Trail from Sixth Crossing to Rock Creek Hollow segment needs to consider explicit management targets, such as minimum acceptable levels of bare ground or trail width, and the establishment of permanent monitoring plots to evaluate targets and measure responses to altered management activities. 


\section{Introduction}

As a result of the 1803 Louisiana Purchase, the United States nearly doubled in size. Oregon, Washington, and Idaho were still British Territories, but Americans were anxious to settle the new region. Over the preceding century, hundreds of thousands of migrants entered the American West along four major routes: the California, Mormon Pioneer, Pony Express, and Oregon Trails. From central Nebraska to central Wyoming, the four trails followed approximately the same route (National Park Service, 1999). Trail use diminished by 1870 when the Union Pacific Railway Company completed the first transcontinental railway. Despite a substantial decrease in use, these trails still were used as a secondary transportation corridor well into the early 1900s. Today (2008), these historic trails have been given a National Historic Trail designation, which recognizes their significance in America's history (National Park Service, 1999).

Travel along the Mormon Pioneer National Historic Trail (hereinafter "the Trail") was begun by the Brigham Young Pioneer Company in 1846, and by 1869 , about 70,000 members of The Church of Jesus Christ of Latter-Day Saints (hereinafter referred to as Mormons or the Mormon Church) had traveled the 2,087-kilometer-long trail from Nauvoo, Illinois, to Salt Lake City, Utah (National Park Service, 2007). Initially, the Brigham Young Pioneer Company led the first group of Mormon trekkers west to Omaha, Nebraska, where they overwintered before continuing west through Wyoming in 1847. Brigham Young was a member of this party, leading 148 Mormon pioneers and 72 wagons to their new home in the Salt Lake Valley (National Park Service, 2007). Along the way, trail markers, ferries, bridges, and supply stations were established to aid future Mormon emigrants. As the Mormon Church grew, immigrants from Europe used handcarts to carry their belongings as they traveled west along the trail. Handcarts could be pushed or pulled, were inexpensive, easier to maneuver and faster than stock-drawn wagons, and could carry as much as 227 kilograms. Ten handcart companies assisted nearly 3,000 people across the Great Plains between 1856 and 1860 (National Park Service, 1999).

A substantial increase in public use of Historic Trails occurred during the 1976 U.S. Bicentennial wagon train reenactment and the subsequent 1990, 1993, 1997, and 1999 reenactments (Bureau of Land Management, 2004). The Trail began to receive even greater use as the Mormon Church became increasingly interested in conducting handcart reenactment treks in the Fremont County area of Wyoming in 1999. From 2001 through 2006, 70,000 trekkers participated in pioneer handcart reenactments along the Rocky Ridge area of the Trail in Wyoming (Jared Oakleaf, BLM Lander Wyoming Field Office, unpub. data, 2007). Because of its scenic value and high potential to afford modern users an opportunity to vicariously share the experience of the original migrants, this trail segment has been designated a high-potential Trail segment (National Park Service, 1999). Recent increased recreational use in the Rocky Ridge area of the Trail has raised concern about the potential for wagons, handcarts, and motorized support vehicles to adversely affect Trail resources (Bureau of Land Management, 2004).

The Bureau of Land management (BLM) is the administering agency for the Trail through much of Wyoming. To make sound decisions about compatible use, the BLM managers require quantitative information relating trail use with resource condition that will inform management decisions on sustainable levels of Trail use. There is a clear need, therefore, to understand the effects of Mormon Pioneer trek reenactments on the Trail and to develop defensible levels of use that will allow the Trail to remain in a relatively unaffected state.

In an effort to manage increased levels of trail use, the BLM began issuing Special Recreation Permits (SRP) "as a means to manage visitor use and protect recreation and other resources, while minimizing adverse resource and cultural impacts, and to reduce user conflicts" (Bureau of Land Management, 2004). In 2005, BLM issued an SRP to the Latter Day Saints (LDS) Farm Management Company for the use of BLM lands between Sixth Crossing and Rock Creek Hollow for handcart treks from June 15 through September 15. A total of 7,500 people (hereinafter "trekkers") per season were allowed under this SRP, with a maximum of 200 people per trek group. The SRP also established guidelines for support vehicles, staging areas, and portable toilets. Additionally, it outlined a monitoring plan to assess effects on wildlife, vegetation, soils, route widening, invasive/alien species, cultural artifacts, and conflicts with private landowners and other trail visitors (Bureau of Land Management, 2005).

The Mormon Pioneer Historic Trail Management and Use Plan Update and Final Environmental Impact Statement (National Park Service, 1999) defines "significant resources" as areas of historical significance, visible historical remnants, above-average scenic quality, or areas having relative freedom from intrusion. The Environmental Assessment addressing the SRP to conduct handcart trek reenactments along the Trail between Sixth Crossing and Rock Creek Hollow states that all historical sites and cross-country trail segments will be managed to protect significant resources; uses that are incompatible with historical preservation of trail sites and segments will be monitored and, if necessary, will be made to become compatible (Bureau of Land Management, 2004).

\section{Purpose and Scope}

The goal of this project was to provide the BLM with a quantitative description of the effects of reenacted Mormon handcart treks on vegetative condition along a 40-km section of the Trail between Sixth Crossing and Rock Creek Hollow in Wyoming. Currently, no quantitative baseline exists with which to develop management guidelines and to address 
potential effects of handcart trekking on the Trail. The purpose of this study was to provide BLM with an assessment of the effects of trekkers on vegetative cover conditions by comparing on- and off-trail locations through comparisons of handcart-traffic intensities using high-resolution aerial photography.

\section{Study Area}

The 40-km segment of the Trail that extends from the Sixth Crossing of the Sweetwater River to Rock Creek in Fremont County, Wyoming, is an area that has substantial seasonal use by Mormon handcart reenactments (fig. 1). The study area extent is bounded in the northeast near the Sweetwater Station at long $108^{\circ} 11^{\prime} 2.1^{\prime \prime}$ W., lat $42^{\circ} 31^{\prime} 57.3^{\prime \prime}$ N. and the confluence of the Sweetwater River and Rock Creek at long $108^{\circ} 37^{\prime} 26.4^{\prime \prime} \mathrm{W}$., lat $42^{\circ} 26^{\prime} 27.4^{\prime \prime} \mathrm{N}$. in the southwest (fig. 2).

\section{Physical Setting}

The study area is predominately sagebrush-steppe intermixed with desert shrubland and is represented by high desert ecosystems with elevations ranging from 1,859 to $2,195 \mathrm{~m}$. Precipitation in the form of spring rains and winter snowfall ranges from 20.3 to $35.6 \mathrm{~cm}$ per year (Roberts, 1989). Summer thunderstorms are common and can contribute substantial amounts of precipitation over short periods. Temperatures reach $-18^{\circ} \mathrm{C}$ in winter and approach $37^{\circ} \mathrm{C}$ during summer.

Dominant vegetation includes Wyoming big sagebrush (Artemisia tridentata subspecies wyomingensis) and Basin big sagebrush (A. t. subspecies tridentata) overstory, under which western wheatgrass (Pascopyrum smithii), bluebunch wheatgrass (Pseudoroegneria spicata), Indian ricegrass (Achnatherum hymenoides), needle-and-thread grass (Stipa comata), indian paintbrush (Castilleja angustifolia), buckwheat (Eriogonum spp.), and evening primrose (Oenothera caespitosa) grow. Several species of invasive nonnative plants such as cheatgrass (Bromus tectorum) and leafy spurge (Euphorbia esula) are common in the study area (Bureau of Land Management, 2004) and may respond positively to trail disturbances. Along the Sweetwater River are riparian zones and wet meadows containing sedges (Carex spp.), rushes (Juncaceae spp.), willow (Salix spp.), chokecherry (Prunus virginiana), and inland saltgrass (Distichlis spicata) (Bureau of Land Management, 2004).

Common wildlife include pronghorn (Antilocapra Americana), mule deer (Odocoileus hemionus), and moose (Alces alces); raptors such as ferruginous hawk (Buteo regalis), Swainson's hawk (Buteo swainsoni), and golden eagle (Aquila chrysaetos) also occur. Known sensitive species include sage thrasher (Oreoscoptes montanus), loggerhead shrike (Lanius ludovicianus), Brewer's sparrow (Spizella breweri), sage sparrow (Amphispiza belli), greater sage-grouse
(Centrocercus urophasianus), mountain plover (Charadrius montanus), northern leopard frog (Lithobaties pipiens), and boreal toad (Bufo boreas) (Bureau of Land Management, 2004). Domestic livestock, including cattle and horses, graze on private and public lands along the Trail.

\section{Geologic Setting}

Much of the soils in the study area derive from Tertiary claystones, sandstones, and conglomerate. However, diverse rock types exist along the Trail, ranging in age from Quaternary alluvium and colluvium to Precambrian granite and metasediment (Love and Christiansen, 1985). East of Rocky Ridge, outcrops and soils are derived from the Oligocene White River Formation (Love and Christiansen, 1985). Rocky Ridge, the highest point on the Trail, is composed of older rocks including the Cambrian Flathead Sandstone, Permian Phosphoria Formation, and the Upper Mississippian Madison Limestone. Precambrian metavolcanics, metasediments, and granite also are present in the vicinity of Rocky Ridge (Love and Christiansen, 1985).

To the west of Rocky Ridge is a mix of Miocene sedimentary rocks including arkosic sandstone, conglomerate, siltstone, and claystone. Outcrops of granitic and metamorphic rocks occur farther west. Soils in the western part of the study area contain more organic-rich material than those in the eastern part. Lowland areas of seasonably wet soils support a variety of grasses and herbs (Love and Christiansen, 1985).

\section{Methods of Investigation}

The following sections describe the methods used to assess the effects of handcart reenactments on the Trail. The methods include aerial photo acquisition and orthorectification, GIS Trail delineation, bare-ground estimates, and statistical analysis of Trail-use data.

\section{Photo Acquisition and Orthorectification}

High-resolution (10-cm) true-color aerial photographs of the studied trail segment were collected during June 2006 by Aero-metric, Inc., of Fort Collins, Colorado. Two hundred and nine frames of photographs were required to completely cover the study area (Appendix 1). Digitally scanned aerial photographs were orthorectified using OrthoMapper ${ }^{\circledR}$ software (Image Processing Software, Inc., 2007). The external orientations for control-point referencing were completed using National Agriculture Imagery Program (NAIP) mosaicked orthophotos, which were acquired in 2006. Subsequent OrthoMapper processing steps included automated aerotriangulation, manual inspection of all tie points, and bundle orthorectification that processes groups of aerial photographs simultaneously. Tie points between 


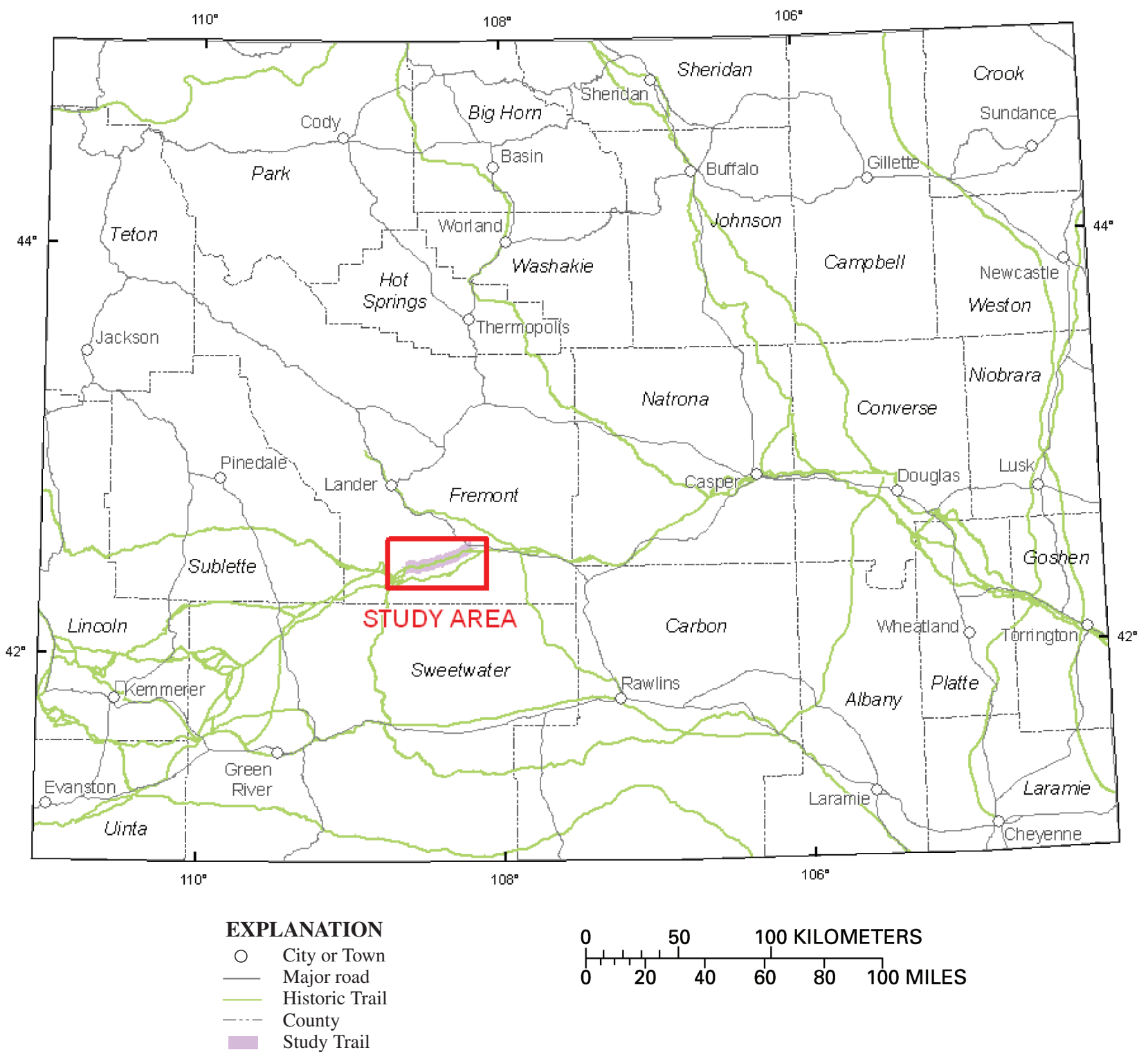

Figure 1. Mormon Pioneer National Historic Trail study area, which extends 40 kilometers west from Sixth Crossing to Rock Creek Hollow, Fremont County, Wyoming. 


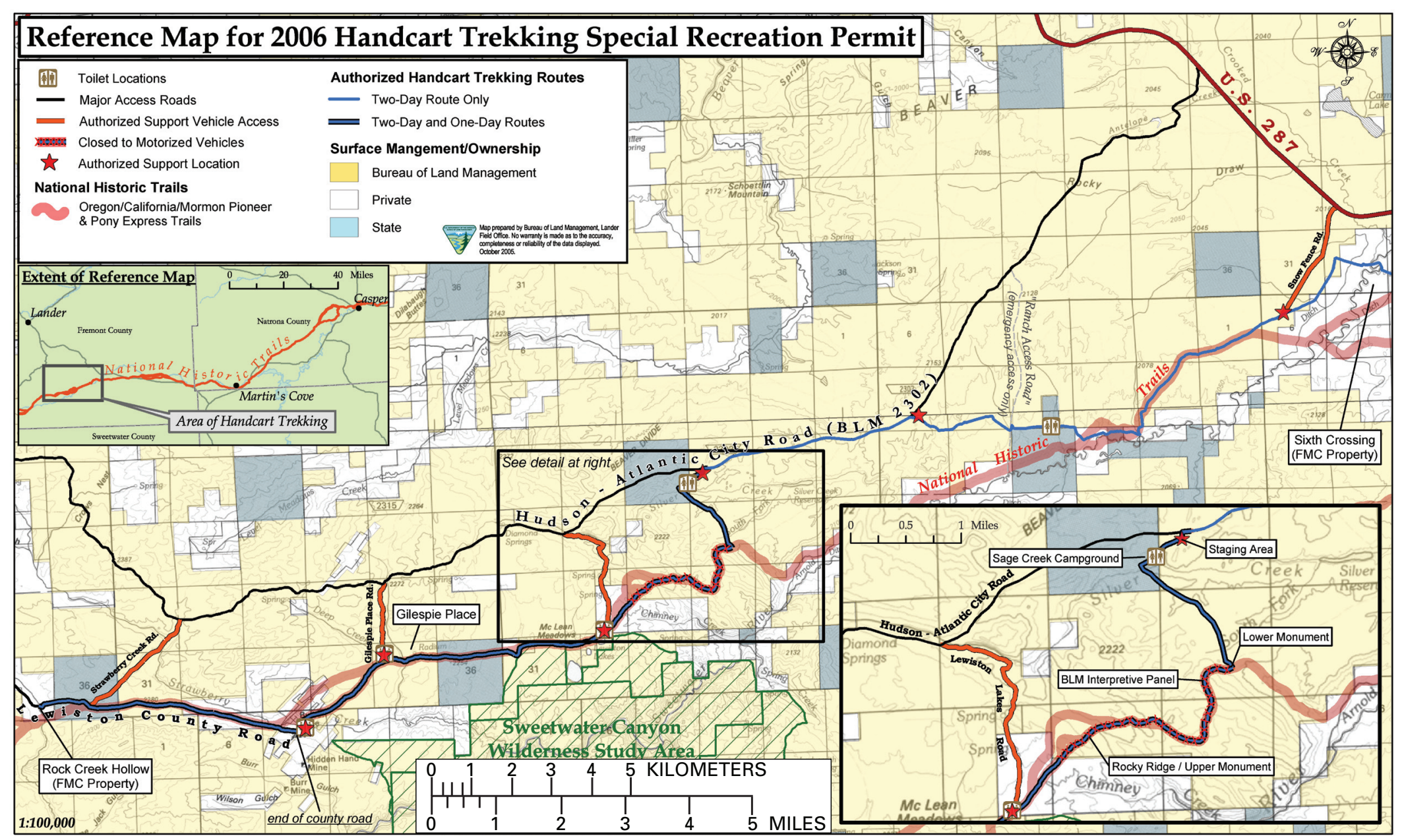

Figure 2. Mormon Pioneer National Historic Trail alignment and Mormon handcart-trekking route between Sixth Crossing and Rock Creek Hollow, Fremont County, Wyoming. 
overlapping aerial photos were used to increase the accuracy of the mosaicking (Appendix 2). The internal (designation of aerial photograph fiducials) orientation for the project referenced the U.S. Geological Survey Report of Calibration for Aerial Mapping Camera (Appendix 2). Nondata portions of each orthorectified aerial photograph were removed, color/ tone balance was applied, and the resulting digital orthophotos were mosaicked in groups to avoid TIFF (tagged image file format) size restrictions (Appendix 3). Survey-grade global positioning system (GPS) ground data were collected (see Appendixes 2 and 3) to estimate the spatial accuracy of both the reference NAIP orthophotos and the orthophotos produced for this project.

\section{Delineation of Historic Trail and Trekker-Use Area}

Applicable roads and trails were digitized as arcs from the digital orthophotos in ERDAS Imagine (ERDAS Imagine, 2006) and attributed in ArcGIS (Environmental Systems Research Institute, 2006). Attribute items in the digitized file included the Trail alignment, handcart trek routes, and other trail and road alignments. For the Trail and handcart routes, confidence was assessed (none, low, moderate, high, or unknown) as to whether or not the arc was part of the Trail or trekker routes. Historical and trekker routes in the geographic information system (GIS) were delineated using spatial data provided by the BLM. Trail delineation and confidence levels were verified with the BLM Lander Field Office recreation planning and archeology staff. Final vectors of the trails were buffered by $110 \mathrm{~m}$ for subsequent assessments of possible trekker effects. Because of the size of the images, the study area digital orthophotos were divided into 19 sections for which final image products were generated for analysis and display (Appendix 4).

\section{Classification of Imagery to Bare-Ground Estimates}

All 19 sections of imagery were processed with ERDAS Imagine using the unsupervised classification algorithm (ISODATA) to produce 60 reflectance classes. A Maximum Likelihood classifier was used to refine the spectral and spatial output and classify signature values into either a high or moderate likelihood of being bare ground (fig. 3). All image files were exported to ESRI GRID format for spatial analysis (Appendix 5).

\section{Trail-Use Data}

Data on Trail use by trekkers were obtained along sections of the Trail from the BLM Lander Field Office for 2001 through 2006, the period over which use records have been kept. Numbers include "best" estimates of actual use along the 40-km Trail section studied. These estimates are based on reports from the LDS Farm Management Company on their use under SRPs, and on the BLM anecdotal records of casual trekkers and nonchurch-related recreational use. Number of trekkers were categorized by route, including: (1) half-day users making a return trip from the Sage Creek Camp site through the Lower Monument to the Upper Monument on Rocky Ridge, (2) two-day trekkers traveling from Sixth Crossing through to Rock Creek Hollow, and (3) one-day trekkers traveling from Sage Creek Camp to Rock Creek Hollow (fig. 4). Sections of the Trail that were not trekker routes were assumed to have no use by trekkers. Trekker use was categorized as low (Sixth Crossing to Sage Creek), moderate (Rocky Ridge to Rock Creek Hollow), high (Lower Monument to Rocky Ridge), or no use (all unused sections of the Trail) based on mean use per year. Because half-day trekkers returned along the same section of trail in most years, the number of half-day users was doubled to represent twice the actual foot and handcart traffic.

\section{Sampling Design and Analyses}

In order to determine trail width, 200-m transects were generated centered on and perpendicular to the trail centerline, with 30-m spacing between transects (fig. 5). At each transect, trail width was measured in ArcGIS using digitized trail boundaries. Trail edges were interpreted and digitized after visual inspection of the aerial photographs in ArcGIS. Bare-ground estimates were sampled in ArcGIS at 1-m spacing along transects originating at the trail center (for example, 1 observation at the centerline and 100 observations in each direction perpendicular to the centerline). At each sample plot, distance from trail center and transect identity were recorded, and presence (1) or absence (0) of bare ground for that $10-\mathrm{cm}$ pixel (using only the high-confidence classification) and trekker-use level noted. In addition to levels of trekker use, data were summarized within a "no trekker use but motorizedvehicle access-allowed" category and a "no trekker use but no motorized access" category (fig. 6). All trail segments were excluded that were associated with the graded Lewiston County Road, and only the remaining Trail segments with high confidence of trekker use and location accuracy were considered for analysis. In addition to factors associated with Trail location and Mormon handcart use, a suite of sampling and environmental contributing factors were considered including soils, terrain, and the identification of the orthophoto section.

For analyses of trail width, the mean \pm Standard Deviation (SD) trail width by trekker-use category was reported, and generalized linear models (family Gaussian and link identity) were used to identify whether differences existed in trail width among trekker use categories (StataCorp, 2007). Effects on the Trail were assessed by comparing the proportion of bare ground present among use categories and distances 


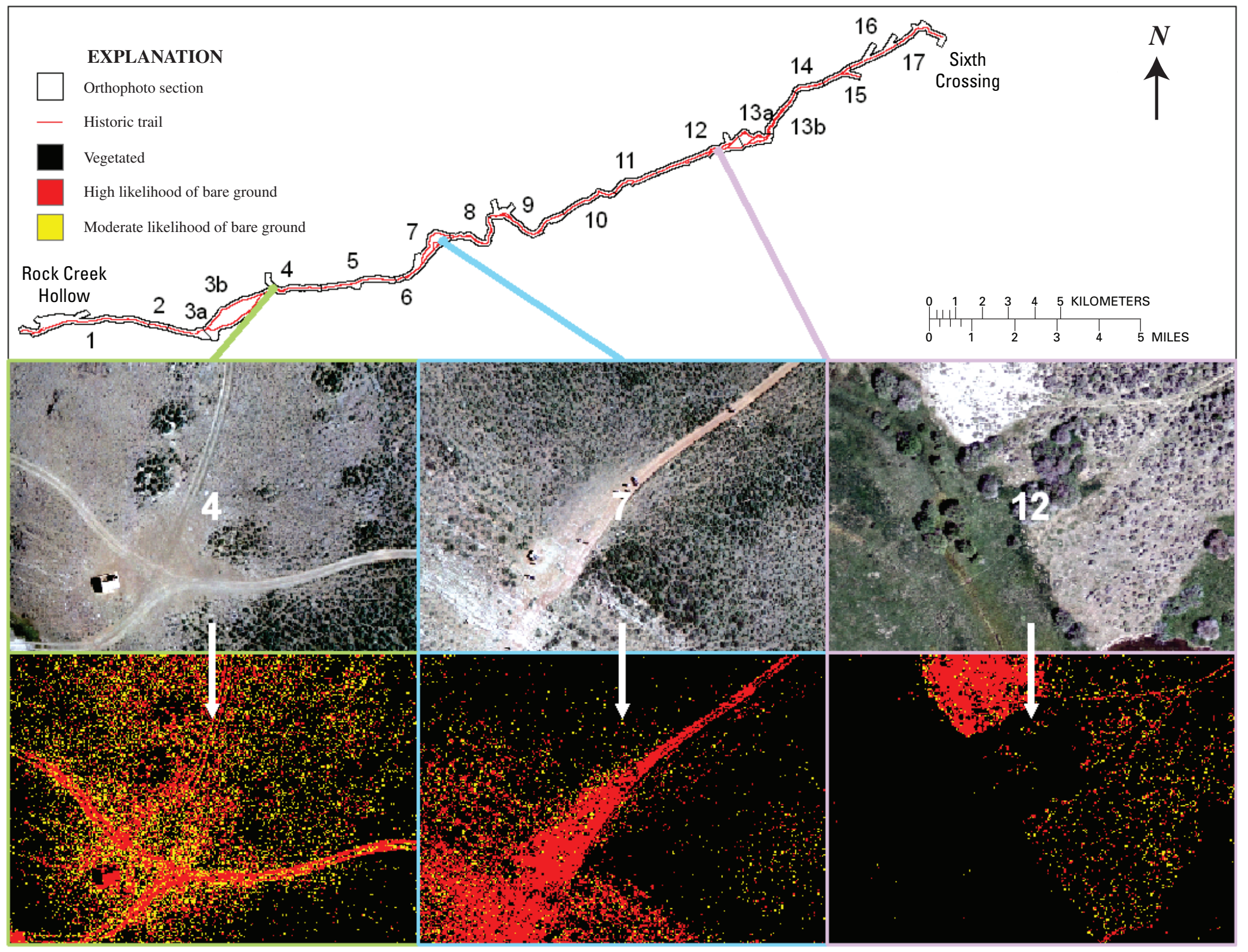

Figure 3. An example of the transition from color aerial photographs (top row) to ERDAS (Earth Resources Data Analysis System) bare-ground class assignments (bottom row). Sample locations (left to right) are: Deep Creek toilet site, Upper Monument, unnamed trail segment. All locations lie between Sixth Crossing and Rock Creek Hollow, Fremont County, Wyoming. High use areas are numbered 1-17 


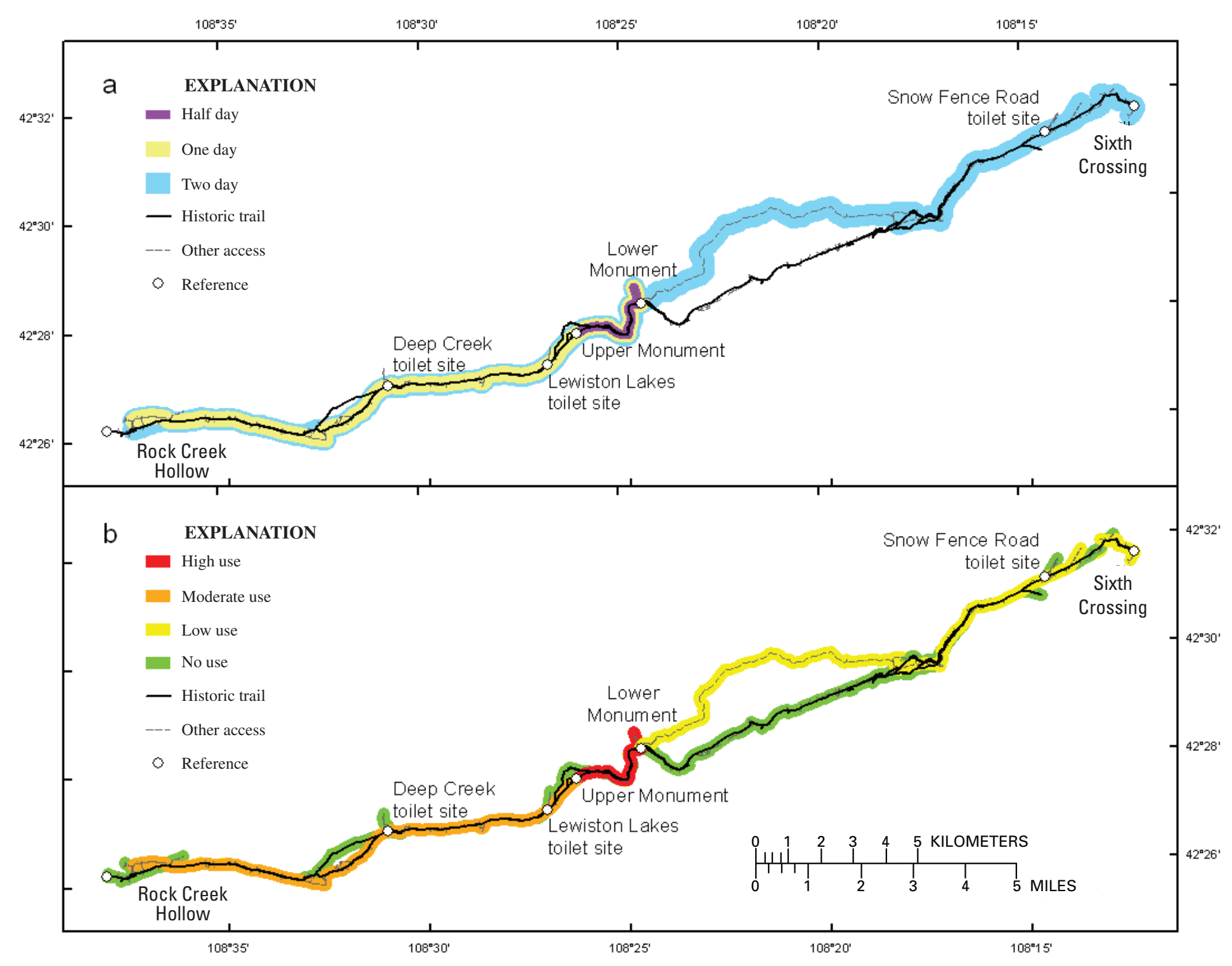

Figure 4. (a) Half-day, one-day, and two-day trekker routes; and four levels of trekker-use intensity (b) along the Mormon Pioneer National Historic Trail between Sixth Crossing and Rock Creek Hollow, Fremont County, Wyoming, 2001 to 2006. (Data based on Bureau of Land

Management (BLM) estimates and recorded use under the Latter Day Saints (LDS) Farm Management Company (FMC) Special Recreation Permit (SRP) during this time period.) 


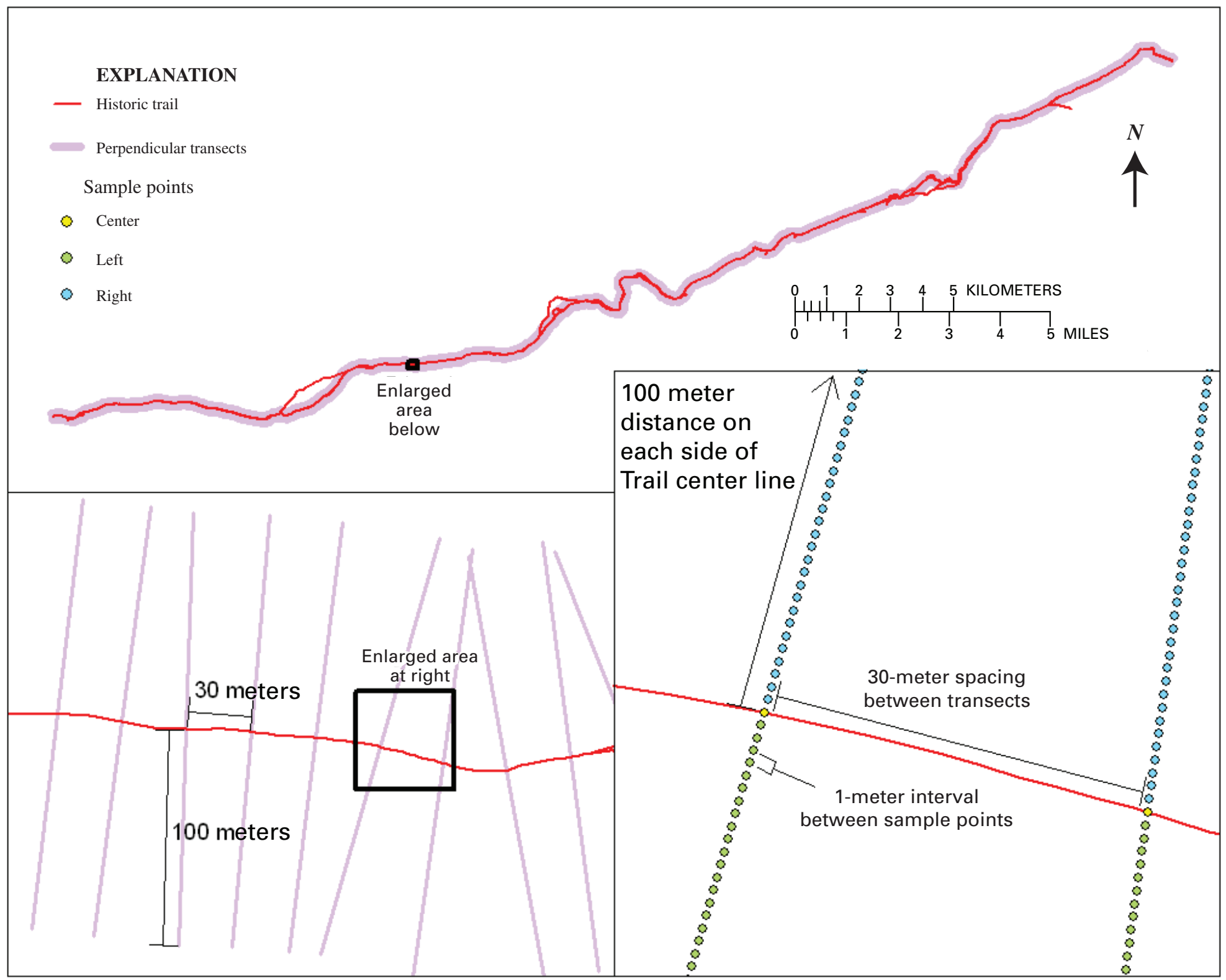

Figure 5. Example of perpendicular transect placement on aerial photographs of the Mormon Pioneer National Historic Trail between Sixth Crossing and Rock Creek Hollow, Fremont County, Wyoming. 


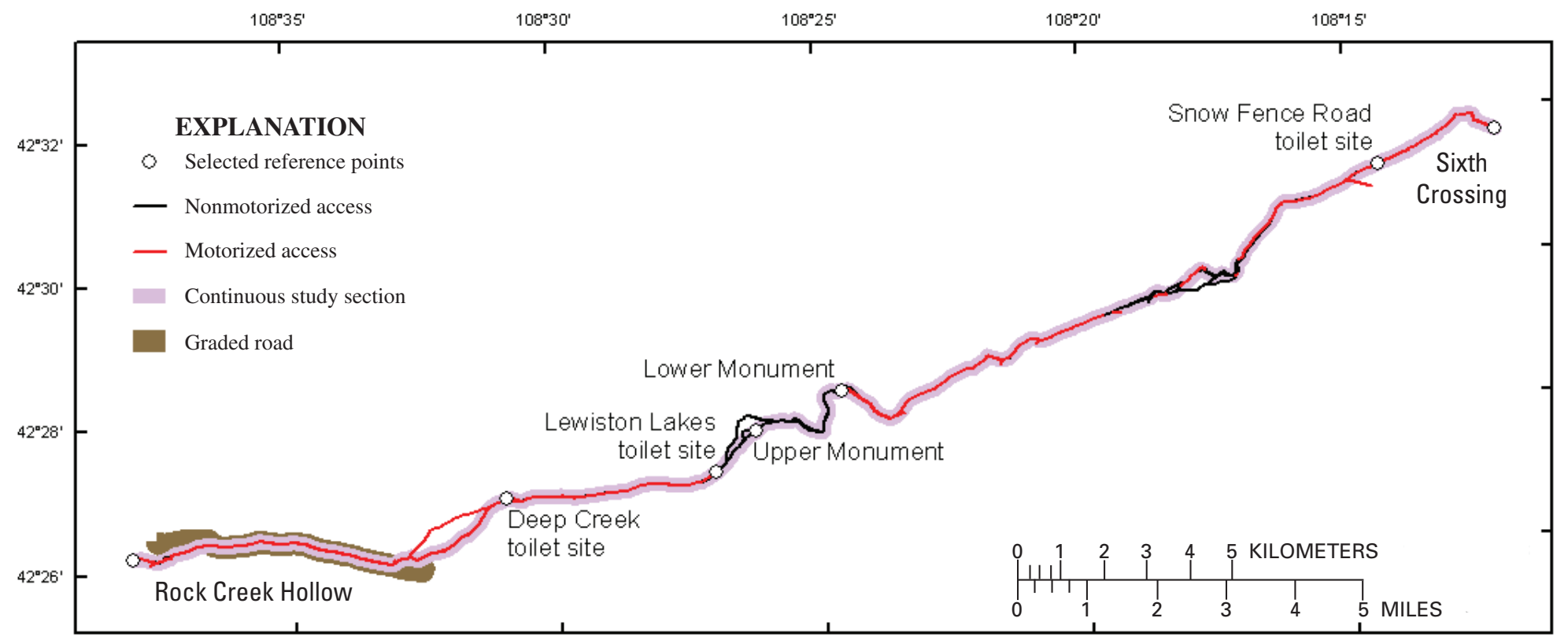

Figure 6. Motorized use on the Mormon Pioneer National Historic Trail between Sixth Crossing and Rock Creek Hollow, Fremont County, Wyoming. 
from trail center. To account for possible contributing effects of soils, terrain, and the 19 orthophoto sections, multivariate logistic regression was used to describe the probability of bare ground (equivalent to proportion of bare ground over broader areas) being present as a result of handcart use intensity and any significant contributing factors. Final model variables were chosen on the basis of model building approaches suggested by Hosmer and Lemeshow (2000). To reduce model complexity, similar categorical variables were combined for soil type and orthophoto section. Indicator contrasts were identified for reference categorical variables by using either the most common category for ancillary variables or the most logical "control" variable for handcart-use categories (in this instance, no handcart use, but motorized access). The significance of categorical variables was therefore based on differences from the reference category. Finally, variance inflators were used to account for nonindependence of sample plots within transects by "clustering" (grouping) observations for each transect. It was assumed, however, that observations between transects were independent.

To assess whether the amount of bare ground differed between concentrated-use (toilet and rest stops; fig. 7) and randomly available sites, the perimeter of nine designated concentrated-use areas were digitized using aerial imagery in ArcGIS (Environmental Systems Research Institute, 2006). For each of the 9 concentrated-use-site polygons, 30 random polygons were generated $(n=270)$ using a custom Visual Basic for Applications (VBA) ArcObjects script that copied the original polygons (to maintain same shape and size) and moved to point locations (of the same centroid distance from the Trail centerline) that had previously been randomly selected using Hawth's Analysis Tools (Beyer, 2007) (fig. 8). ArcGIS software was used to measure the percentage of bare ground in each polygon (concentrated use or random) after tallying the number of pixels classified as "high confidence bare" or "other."

Two methods were used to determine whether the amount of bare ground differed between concentrated-use and random sites. First, 30 random polygons for each concentrated-use site were used to generate 95-percent confidence intervals describing the general incidence of bare ground along the Trail. Individual concentrated-use sites were compared against these intervals, and those having bare-ground values outside the 95-percent confidence interval were considered affected. This analysis allowed each of the nine concentrated-use areas to be assessed individually. In addition, bare ground was averaged for random sites associated with each concentrated-use site and compared against the observed concentrated-use-site values in a one-way t-test, under the null hypothesis that the amount of bare ground at concentrated-use sites was not greater than in random nonaffected plots of same size, shape, and distance from the Trail. All tests and comparisons were made using Stata (StataCorp, 2007) software with an alpha value $=0.05$ and report means $\pm \mathrm{SD}$.

\section{Results}

\section{Trekker-Use Data}

From 2001 to 2006, an average of 11,686 individuals per year reenacted Mormon handcart treks along the Mormon Pioneer National Historic Trail between Sixth Crossing and Rock Creek Hollow in Wyoming (table 1), with a maximum number of 16,713 individuals in 2002. Permitted use along the Trail since 2001 varied over time and among sections of the Trail with the lowest permitted use occurring in 2006 (7,235 trekkers) and the highest permitted use $(13,113$ trekkers) in 2002 (table 1). Recorded casual use also varied by year, with as few as 300 trekkers in 2001 to more than 3,000 casual trekkers in 2002 and 2004 (table 1).

\section{Depiction of Trail and Other Spatial Data}

Through examination of the aerial photography in ArcGIS by the BLM Lander Field Office and USGS staff, the mapped accuracy of the Trail between Sixth Crossing and Rock Creek Hollow in at least 76 distinct places was improved. Of the total $65.3 \mathrm{~km}$ (40.6 mi) of trail delineated, high confidence of Trail location (spatial accuracy) was assigned to $54.6 \mathrm{~km}$ (33.9 mi) of trail, moderate confidence to $4.5 \mathrm{~km}(2.8 \mathrm{mi})$ of trail, and low confidence for $6.2 \mathrm{~km}$ (3.9 mi) of trail. When summed across the entire study trail segment, there were $38.0 \mathrm{~km}(23.6 \mathrm{mi})$ of no-use trail, $6.8 \mathrm{~km}(4.2 \mathrm{mi})$ of low-intensity-use trail, $14.8 \mathrm{~km}(9.2 \mathrm{mi})$ of medium-use trail, and $3.4 \mathrm{~km}(2.1 \mathrm{mi})$ of high-trekkeruse trail. There was no statistical difference between the spatial accuracy of the reference NAIP orthophotos and the orthophotos produced for this project (Appendix 2).

After considering the overlap of reenactment routes, three distinct intensities of trekker use were evident (fig. 9). On the east side of the Trail (for example, Sixth Crossing to Sage Creek Campground; fig. 2), trekker use was the lowest with a cumulative level of use from 2001 to 2006 averaging $3,963$ ( $\pm 1,032 \mathrm{SD})$ trekkers per year (fig. 9). In comparison, the west end of the trail (for example, Rocky Ridge to Rock Creek Hollow; fig. 2) received moderate use, averaging $8,304( \pm 3,654)$ users per year (fig. 9). Finally, where all three trekking routes overlapped at Lower Monument and Rocky Ridge (fig. 2), the cumulative number of trekkers was 12,240 $( \pm 3,520)$ per year with a total of 74,400 trekkers using this section from 2001 to 2006 (fig. 9).

\section{Effects of Trekkers on Bare Ground}

The following sections describe the results of the analyses of the effects of trekker use on bare-ground areas near and on the Trail. The analyses include trail width, patterns of bare ground, and the effects of off-trail activity on vegetation. 


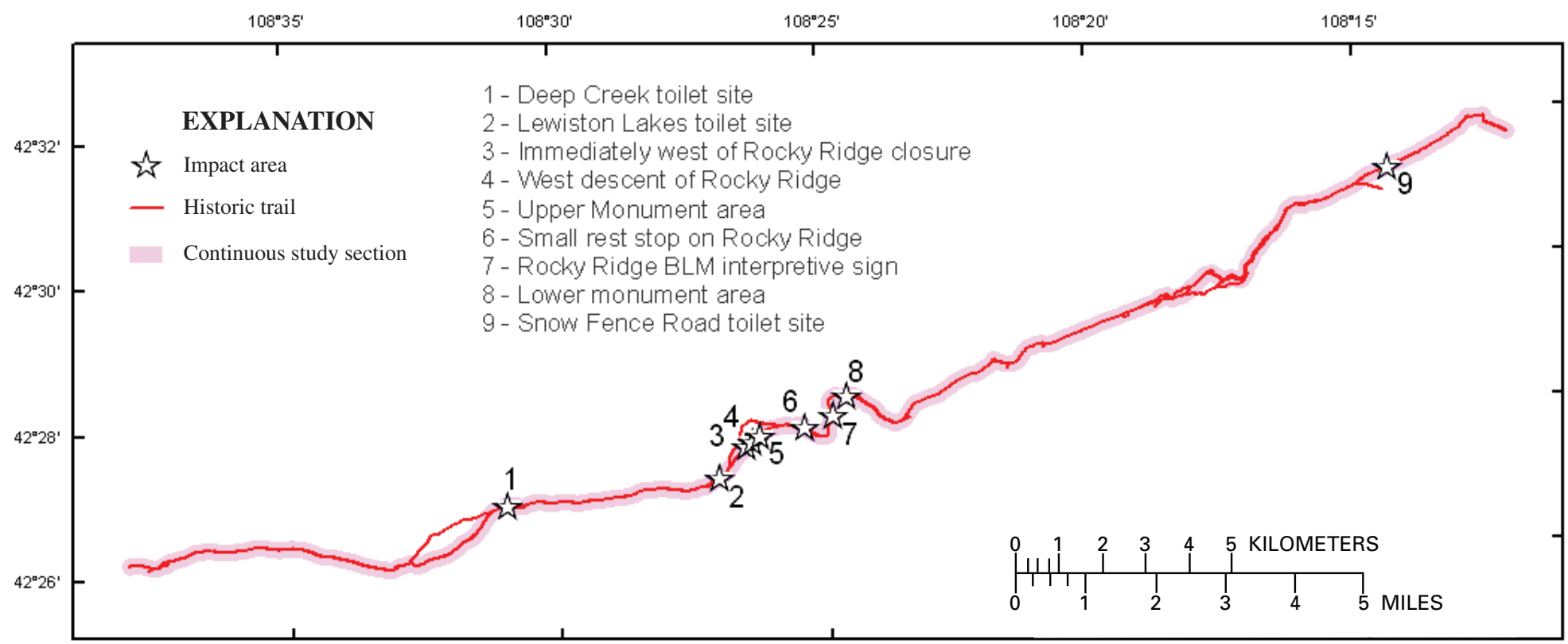

Figure 7. Location of nine concentrated-use areas along the Mormon Pioneer National Historic Trail between Sixth Crossing and Rock Creek Hollow, Fremont County, Wyoming. 


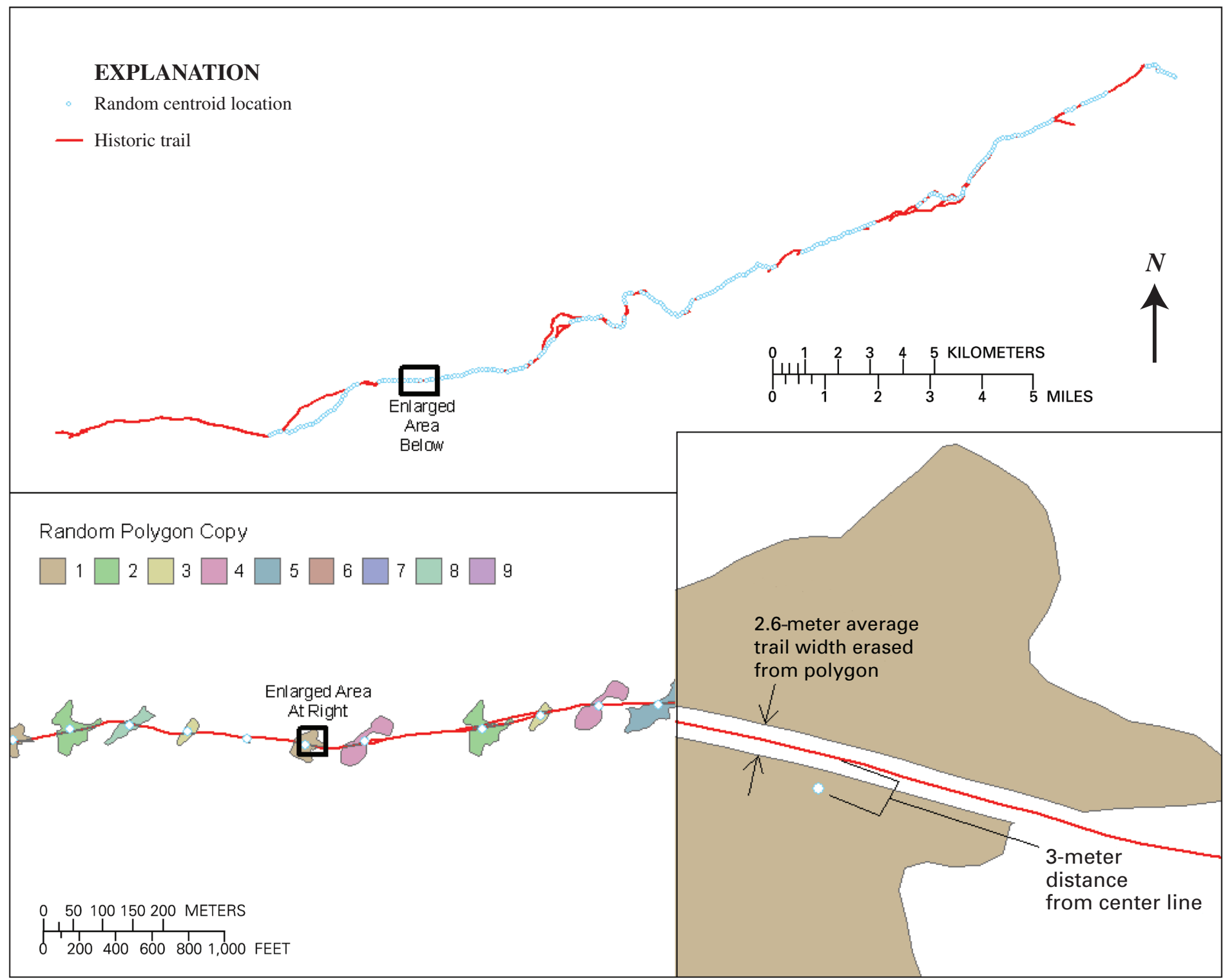

Figure 8. Concentrated-use and random area polygons within which the percentage of bare ground versus vegetated ground were summed. Thirty random polygons ("copies") were generated for each of the nine concentrated-use areas analyzed (see fig. 7). Random polygons were of same size, shape, and average overall centroid distance (2.6 meters) from trail center as the concentrated-use polygon they were associated with. 
Table 1. Estimated number of handcart users along three distinct reenactment routes. Numbers are based on permitted users recorded from Bureau of Land Management (BLM) Special Recreation Permits (SRP) and casual users recorded by BLM staff from 2001 to 2006.

\begin{tabular}{|c|c|c|c|c|c|c|c|c|c|}
\hline \multirow[b]{2}{*}{ Route } & \multicolumn{3}{|c|}{2001} & \multicolumn{3}{|c|}{2002} & \multicolumn{3}{|c|}{2003} \\
\hline & Permitted & Casual & Total & Permitted & Casual & Total & Permitted & Casual & Total \\
\hline Half Day & 1,070 & 100 & 1,170 & 800 & 400 & 1,200 & 30 & 100 & 130 \\
\hline Two Day & 2,643 & 100 & 2,743 & 5,164 & 200 & 5,364 & 3,905 & 300 & 4,205 \\
\hline One Day & 4,818 & 100 & 4,918 & 7,149 & 3,000 & 10,149 & 6,330 & 300 & 6,630 \\
\hline Total & 8,531 & 300 & 8,831 & 13,113 & 3,600 & 16,713 & 10,265 & 700 & 10,965 \\
\hline Half Day & 0 & 100 & 100 & 519 & 100 & 619 & 0 & 100 & 100 \\
\hline Two Day & 4,228 & 200 & 4,428 & 4,092 & 200 & 4,292 & 2,545 & 200 & 2,745 \\
\hline One Day & 6,615 & 3,000 & 9,615 & 6,620 & 200 & 6,820 & 4,690 & 200 & 4,890 \\
\hline Total & 10,843 & 3,300 & 14,143 & 11,231 & 500 & 11,731 & 7,235 & 500 & 7,735 \\
\hline
\end{tabular}

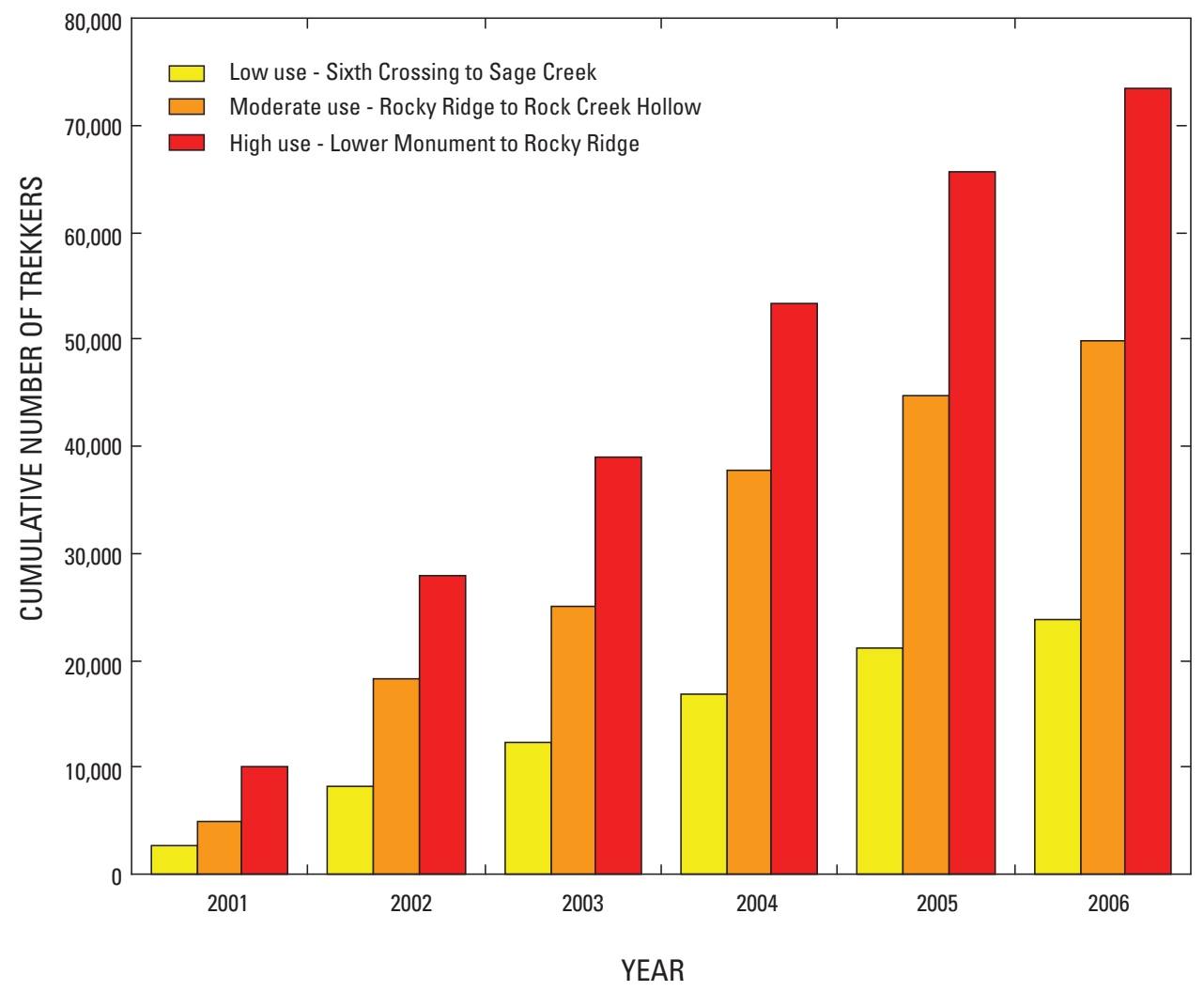

Figure 9. Cumulative number of Mormon trekkers in each of three use levels on the Mormon Pioneer National Historic Trail between Sixth Crossing and Rock Creek Hollow, Fremont County, Wyoming, 2001 to 2006. 


\section{Patterns in Trail Width by Trekkers}

Trail width, as determined by photo imagery and interpretation, averaged $2.5( \pm 0.7 \mathrm{SD})$ meters for segments of the Trail with trekker use or known motorized access and only $0.2( \pm 0.6 \mathrm{SD})$ meter in width for segments of the Trail with no known motorized access or trekker use (fig. 10). For many areas of the Trail where handcart use and public motorized access was limited, little if any evidence of disturbance in vegetation and soils was apparent, indicating ecological recovery from historical disturbances. Among handcart use intensities, as well as control areas where handcart use was absent but where there was motorized access, no significant difference in trail width was evident. Thus, trail width was not used in further analyses.

\section{Patterns of Bare Ground On and Off the Trail by Mormon Handcart-Use Intensity}

Using classified bare-ground estimates and GIS-based sampling, measurements of bare ground along active trails show a hump-shaped pattern when plotted against distance from trail center (fig. 11). Bare-ground values range from 57 percent at trail center locations in areas having no handcart use but are open to motor vehicles to 92 percent at $1 \mathrm{~m}$ from the trail center in areas having moderate handcart use. Off the trail ( $\geq 2 \mathrm{~m}$ ) bare-ground averages ranged from about 12 percent for moderate handcart use to about 20 percent for no handcart use, but with motorized access (table 2, fig. 12).
Generally, trekking activities appear to add an additional 3 to 18 percent bare ground at distances of 0 to $2 \mathrm{~m}$ from trail center when compared to areas of the Trail with no handcart use, but with active motorized access (fig. 13). Ground disturbance at the trail center location appeared to be more consistent among handcart-use intensities ranging from an additional 13 percent (low handcart use) to 18 percent (moderate handcart use). At 1-m distances, however, low handcart-use activity had little apparent effect (3 percent more bare ground) when measured against control (no handcart use, motor-vehicle-accessible areas, fig. 13).

More substantial effects were evident for moderate and high handcart-use activities at the 1-m distance class (12 and 17 percent, respectively). Contrary to what might be expected, moderate handcart use had higher amounts of on-trail bare ground than high handcart use, although differences appeared to be rather minor ( 2 to 5 percent) and may reflect contributing factors associated with landscape characteristics and photo acquisition.

Logistic regression models at the 0 - and 1-m distance classes indicate similar patterns of bare ground, regardless of handcart use intensity, after accounting for the contributing effects of soil type and photo imagery section (table 3; see Appendix 6 for detailed descriptions of analyses). Only low handcart use at the $0-\mathrm{m}$ trail center distance and moderate handcart use at the 1-m trail center distance differed substantially from control segments (for example, no handcart use, motorized, table 3). Trail effects from trekking therefore were attenuated once contributing factors were included (Appendix 6; figs. 14 and 15).

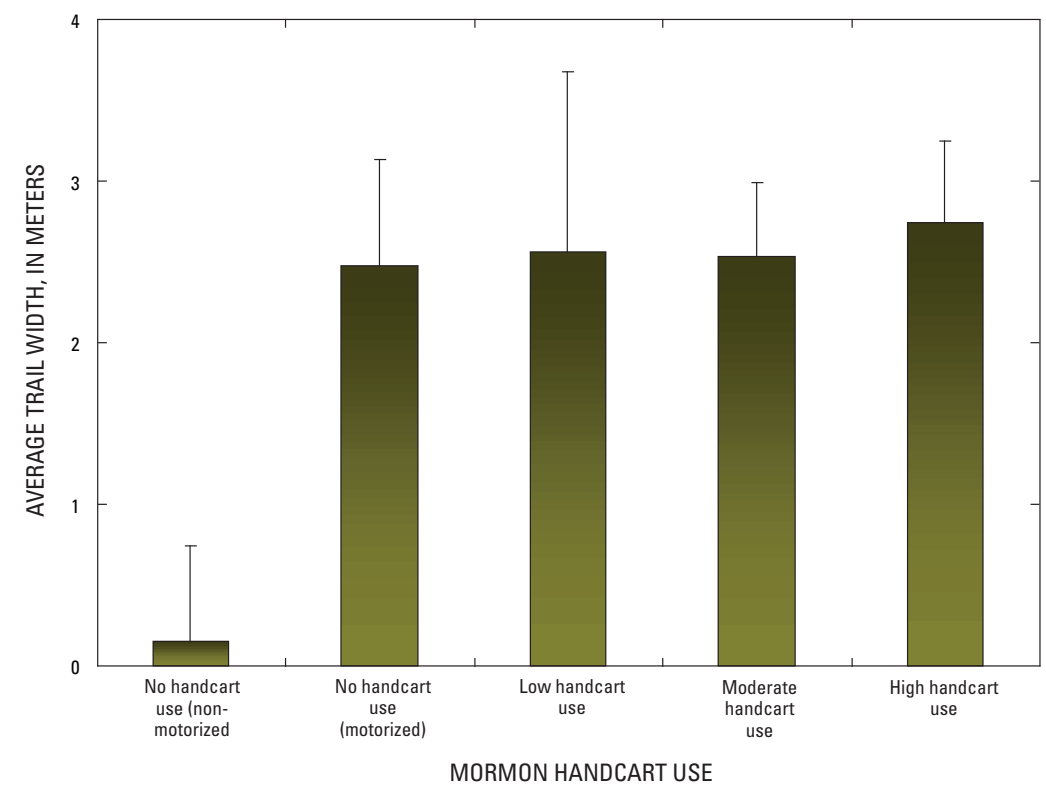

Figure 10. Average trail-width values for five Mormon handcart-use intensity levels on the Mormon Pioneer National Historic Trail between Sixth Crossing and Rock Creek Hollow, Fremont County, Wyoming, 2006. 


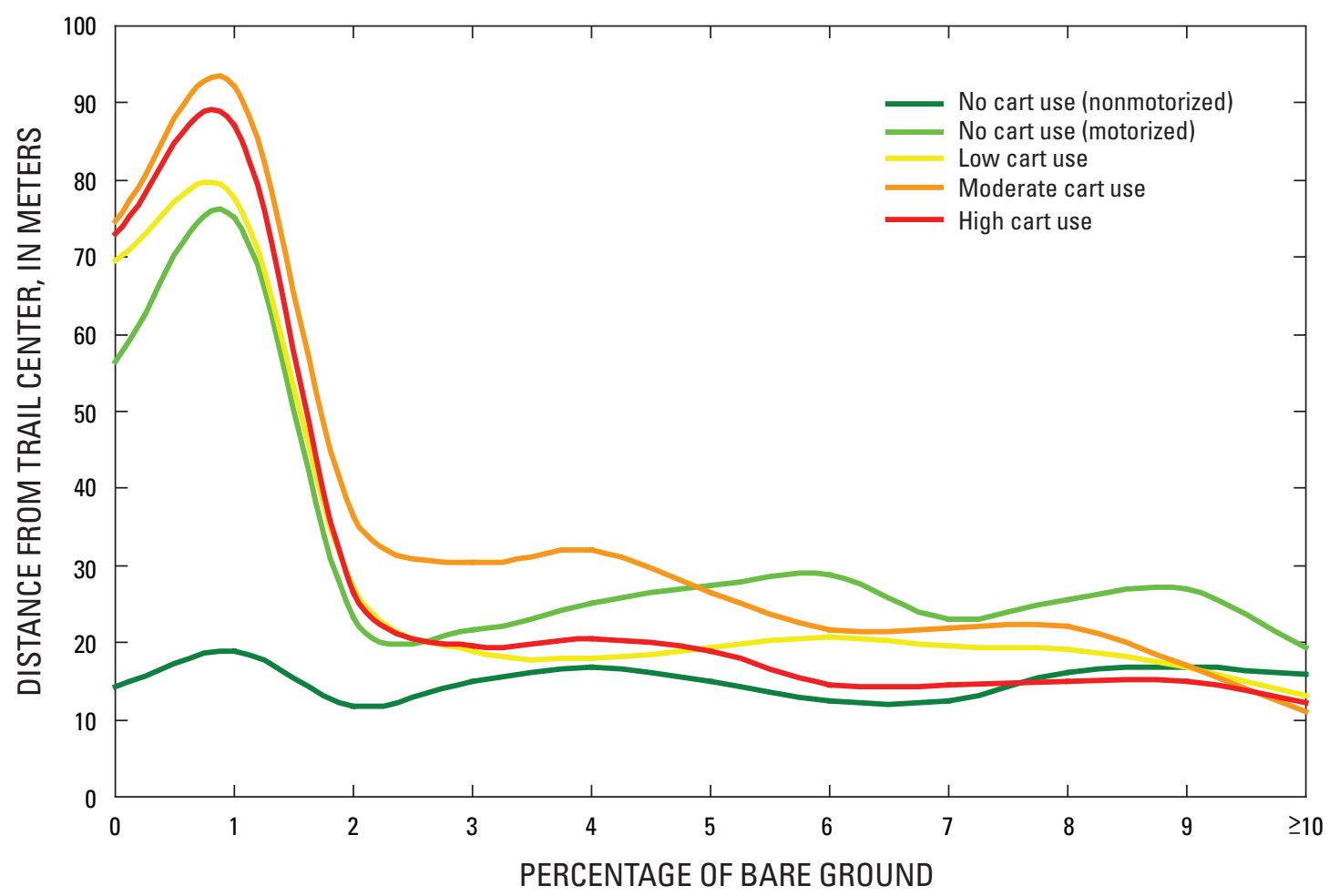

Figure 11. Average percentage of bare ground by category of Mormon handcart use and distance from trail center along the Mormon Pioneer National Historic Trail between Sixth Crossing and Rock Creek Hollow, Fremont County, Wyoming.

Table 2. Average percentage of bare ground in five Mormon handcart-use intensity levels and three distance classes from trail center along the Mormon Pioneer National Historic Trail between Sixth Crossing and Rock Creek Hollow, Fremont County, Wyoming.

\begin{tabular}{lccc}
\hline \multirow{2}{*}{ Handcart use category } & \multicolumn{3}{c}{ Distance from trail center } \\
\cline { 2 - 4 } & 0 meters & 1 meter & $\geq \mathbf{2}$ meters \\
\hline No handcart use (nonmotorized) & 14.3 & 18.8 & 15.8 \\
No handcart use (motorized) & 56.5 & 75.1 & 19.9 \\
Low handcart use & 69.6 & 77.7 & 13.7 \\
Moderate handcart use & 74.6 & 92.1 & 12.2 \\
High handcart use & 73.0 & 87.0 & 12.7 \\
\hline
\end{tabular}




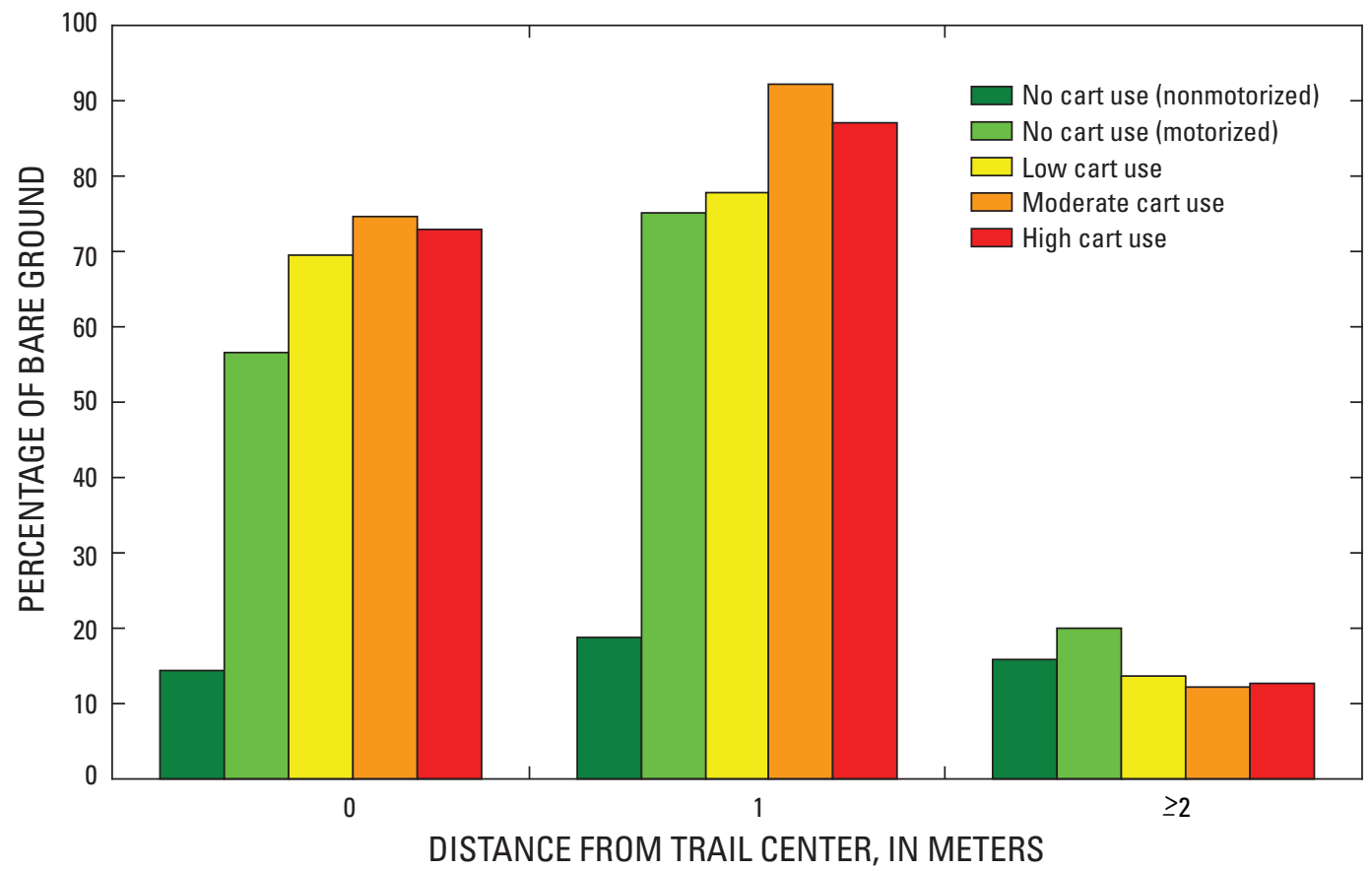

Figure 12. Percentage of bare ground among five Mormon handcart-use intensity levels and three distances from trail center between Sixth Crossing and Rock Creek Hollow, Mormon Pioneer National Historic Trail, Fremont County, Wyoming.

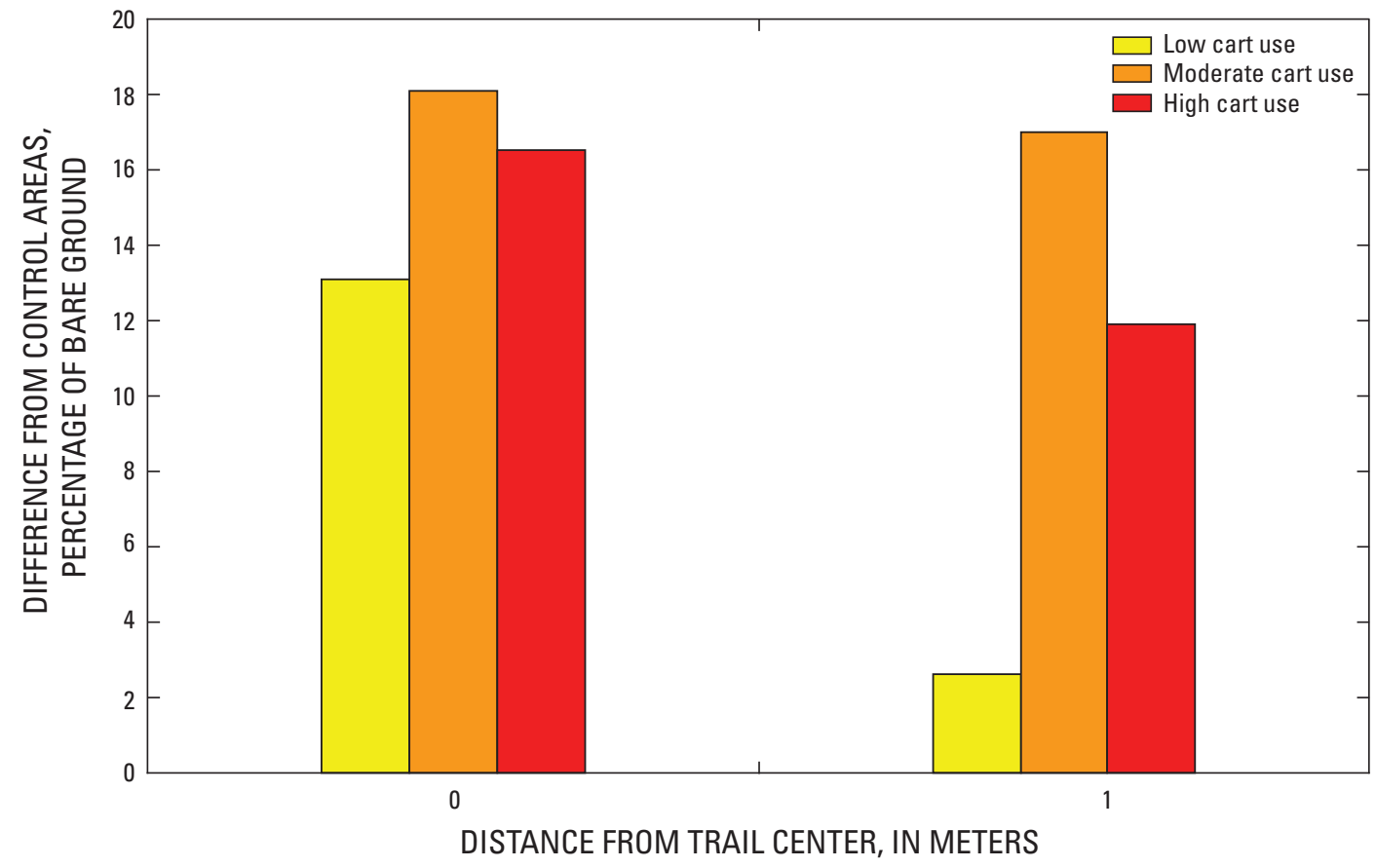

Figure 13. Difference in percentage of bare ground associated with Mormon handcart-use activity by distance from trail center between Sixth Crossing and Rock Creek Hollow, Mormon Pioneer National Historic Trail, Fremont County, Wyoming. Estimates are based on differences between three handcartuse levels and trail- segment control areas, which were assumed to be no-handcart use, but having motorized activity. 
Table 3. Logistic regression results describing the probability of being classified bare ground along the Mormon Pioneer National Historic Trail at two on-trail distances from trail center ( 0 and 1 meter) between Sixth Crossing and Rock Creek Hollow, Mormon Pioneer National Historic Trail, Fremont County, Wyoming.

$[\beta=$ model coefficient, $\mathrm{SE}=$ standard error, $\boldsymbol{p}=$ probability $($ StataCorp, 2007$]$

\begin{tabular}{|c|c|c|c|c|c|c|}
\hline \multirow[b]{2}{*}{ Variable } & \multicolumn{3}{|c|}{ 0-m (trail center) distance } & \multicolumn{3}{|c|}{ 1-m (trail rut) distance } \\
\hline & $\beta$ & SE & $p$ & $\beta$ & SE & $p$ \\
\hline \multicolumn{7}{|l|}{ Handcart-use category* } \\
\hline None (nonmotorized) & -1.313 & 0.415 & 0.002 & -2.095 & 0.297 & 0.000 \\
\hline Low cart use & 0.416 & 0.219 & 0.058 & -0.222 & 0.195 & 0.254 \\
\hline Moderate cart use & -0.040 & 0.320 & 0.901 & 0.715 & 0.348 & 0.040 \\
\hline High cart use & 0.124 & 0.370 & 0.738 & 0.240 & 0.363 & 0.509 \\
\hline \multicolumn{7}{|l|}{ Soil group } \\
\hline Group 1 & 0.320 & 0.324 & 0.322 & 1.245 & 0.381 & 0.001 \\
\hline Group 2 & -0.929 & 0.381 & 0.015 & -2.070 & 0.309 & 0.000 \\
\hline Group 4 & 0.430 & 0.339 & 0.204 & -0.125 & 0.309 & 0.685 \\
\hline \multicolumn{7}{|l|}{ Photo-image group } \\
\hline Group 2 & -1.667 & 0.514 & 0.001 & -1.536 & 0.366 & 0.000 \\
\hline Group 3 & -0.316 & 0.263 & 0.229 & -0.609 & 0.234 & 0.009 \\
\hline Group 4 & 0.169 & 0.235 & 0.473 & -0.134 & 0.222 & 0.544 \\
\hline Group 5 & 0.772 & 0.261 & 0.003 & 0.216 & 0.367 & 0.557 \\
\hline Constant & 0.379 & 0.216 & 0.079 & 1.658 & 0.220 & 0.000 \\
\hline
\end{tabular}

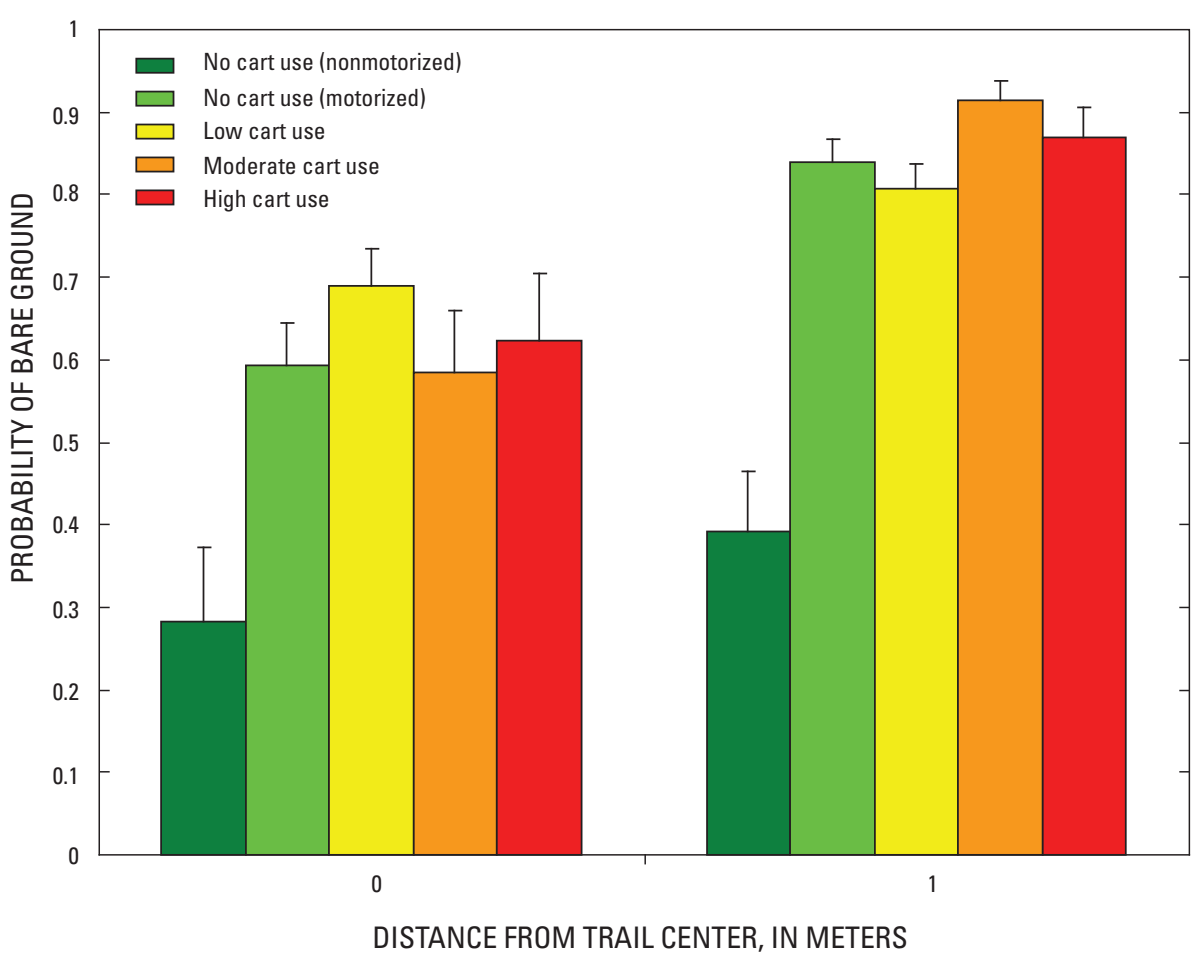

Figure 14. Predicted probability of bare ground plus the standard error (SE) based on handcart use level and distance from trail center, adjusted for soil and photo image effects between Sixth Crossing and Rock Creek Hollow, Mormon Pioneer National Historic Trail, Fremont County, Wyoming (for figure, photo image group 1 and soil group 3 were the reference categories). 


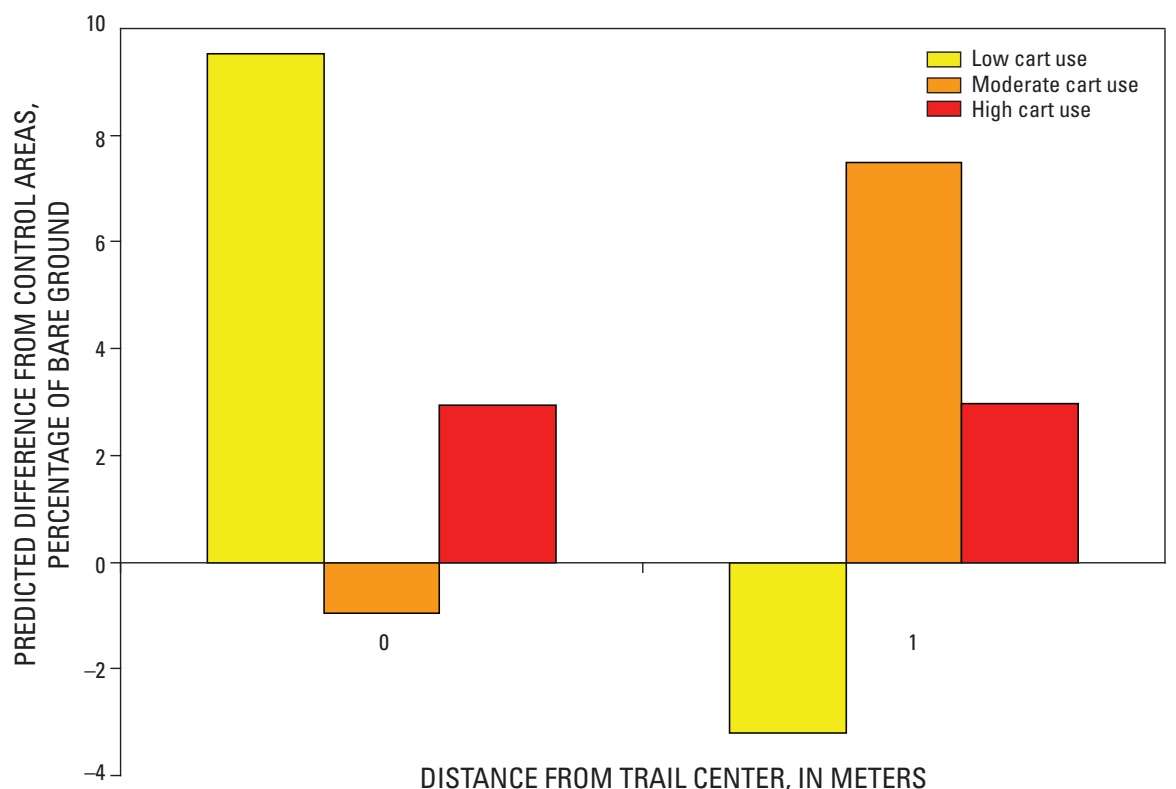

Figure 15. Predicted differences in percentage of bare ground between control and handcart-use sites at trail center and 1 meter distance from trail center, after accounting for soil and photo image variation between Sixth Crossing and Rock Creek Hollow, Mormon Pioneer National Historic Trail, Fremont County, Wyoming.

\section{Patterns of Bare Ground by Concentrated-Use Areas}

Three of the 12 concentrated-use areas identified by BLM Lander Field Office staff are off of the true Historic Trail alignment. Therefore, the nine concentrated-use areas on the alignment were analyzed. The nine sites range in size from 45.7 to $7,237 \mathrm{~m}^{2}(\bar{x}=2,353.8 \pm 2,205.1)$, and the amount of bare ground present at the sites ranged from 13.9 percent at the Rocky Ridge BLM interpretive sign to 82.4 percent at the vehicle parking lot located at the western base of Rocky Ridge (Appendix 6). Average amount of bare ground at control (random) sites averages 20.7 percent and ranges from 17.9 to 25.4 percent. Seven of nine concentrated use sites had significantly higher $(p<0.05)$ levels of bare ground than control sites (fig. 16). Only sites 6 (Rocky Ridge BLM interpretive sign) and 7 (Rocky Ridge rest stop) did not differ from average bare- ground levels elsewhere along the Trail. Overall, concentrated-use sites $(\bar{x}=45.0$ percent \pm 23.6 percent) have significantly higher percentage of bare ground than random sites $(\bar{x}=20.7 \pm 15.7$; one-tailed $\mathrm{t}=-3.192, p=0.006$, Appendix 6, p. 92).

\section{Discussion}

Handcart trekking had no measurable effect on trail widening and relatively minor on-trail effects to vegetation compared to other sources of impact (for example, motorized traffic). The amount of bare ground was explained by soil and photo-imagery variation rather than trekker intensities. Trail width and on-trail vegetation appeared to be influenced by past and current motorized traffic. Trail segments receiving motorized use, but no-handcart use, were substantially wider than trail segments where neither activity occurred. Because most of the area where handcart trekking occurred was open to motor vehicles and no evidence of further trail widening was observed, trekking appears to have no additional effects over motor-vehicle impacts on the Trail itself.

A similar result was obtained when considering on-trail bare-ground patterns. Trail segments receiving motorizedtraffic use but not handcart use had nearly four times the level of bare ground than areas where neither activity occurred. Although the effects of handcart trekking were relatively minor overall, trekking effects did appear to be additive with motorized impacts. Bare ground in areas where handcart trekking and motor-vehicle use coincided averaged 8.5 percent (for 24 soil and photo-type categories) higher at 1-m trailcenter distances than in areas where only motor vehicle activity occurred. Because it was not possible to evaluate trail width or percentage of on-trail bare ground in areas where handcart use occurred in the long-term absence of motor vehicle traffic, the level of trekking effects on otherwise undisturbed trail segments cannot be determined.

Previous research indicates that even a few motor vehicles can reduce live vegetation (Ouren and others, 2007) by 


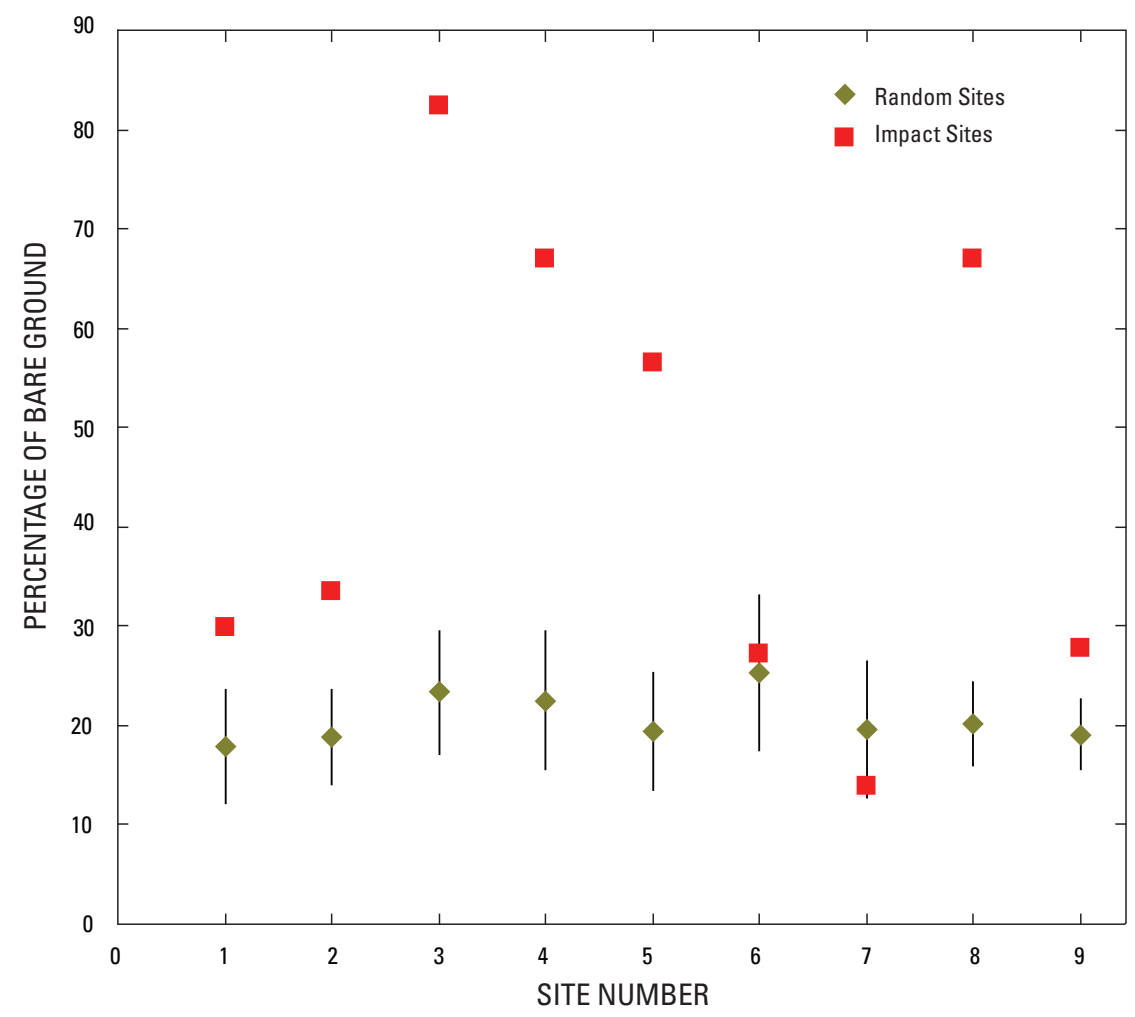

Figure 16. Percentage of bare ground present at concentrated-use and random sites along the Mormon Pioneer National Historic Trail between Sixth Crossing and Rock Creek Hollow, Fremont County, Wyoming. Bars are 95-percent confidence intervals around average bare ground estimates in random plots. $n=30$ random plots per concentrated use site; 1 = Deep Creek toilet; 2 = Lewiston Lakes toilet; 3 = parking lot at vehicle closure gate, west side of Rocky Ridge; 4 = west descent of Rocky Ridge; $5=$ Upper Monument; $6=$ small rest stop, top of Rocky Ridge; $7=$ Rocky Ridge BLM interpretive sign; 8 = Lower Monument; 9 = Snow Fence Road toilet).

damaging plants (Adams and others, 1982; Webb, 1983) or by reducing water availability due to soil compaction (Adams and others, 1982). These effects are exacerbated with increased motorized use (Kutiel and others, 2000). Additional effects associated with motorized traffic can include soil erosion, altered microclimates, introduction of exotic plant species, nutrient (primarily nitrogen) enrichment, increased pollution, and increased fire frequency (Lovich and Bainbridge, 1999; Jordan, 2000). Although these specific effects were not addressed in this study, unmeasured cumulative effects due to motorized vehicle use appear to affect revegetation of the trail and reduced the ability to detect effects from handcart reenactments.

Rapid decreases in bare ground at locations greater than $1 \mathrm{~m}$ from the trail center are consistent with analyses of trail width, which averaged $2.6 \mathrm{~m}$ (1.3 m to either side of trail centerline) along active trail segments. Handcart trekking caused no additional loss of vegetation on off-trail locations ( $\geq 2 \mathrm{~m}$ from the trail center) away from concentrated-use sites (for example, rest and toilet sites). These results are consistent with previous research showing a limited zone (1 to $2 \mathrm{~m}$ ) of influence (Dale and Weaver, 1974; Bjorkman, 1996).

Seven of nine mapped, off-trail, concentrated-use sites contained substantially higher amounts of bare ground than control (random) areas. Concentrated-use sites averaged 45 percent bare ground, more than double the 20 percent bare ground typical of other areas along the Trail. Pit toilets and rest sites are focal points for intense, repetitive trampling from hikers, handcarts, and support vehicles and are particularly susceptible to soil compaction, erosion, and increased invasion of exotic and noxious plants. Careful observation of these sites might be required to prevent irreversible disturbances or the invasion of noxious or invasive exotic plants. Where necessary, management actions, including control of noxious or invasive exotic plants and native revegetation, may be necessary to ensure long-term health of these areas of the Trail. 


\section{Study Limitations}

Several factors that were not accounted for in the analytical design of this study were included as model covariates to control for contributing effects, although it would have been more desirable to implement control of these factors during the study design. Aerial photograph subsection relating to image color balance and soil type were substantially related to observed patterns of bare ground. Although exhaustive efforts were made to color balance the photo images, photo variation in brightness and color likely had an adverse effect on the ability to classify and, therefore, to model bare ground, resulting in reduced statistical power. The drought conditions that occurred in early 2006 further hampered the ability to compare effects of trail use because much of the vegetation was water stressed, which limited green vegetation during the June photography overflight. Thus, bare-ground estimates in the study for June 2006 may be overestimated when compared to average growing-season conditions.

Despite detailed information on trekker use, no quantitative data were available on vehicular traffic volume (past or present) restricting the ability to detect differences in bare ground because of trekker use. It is apparent that past and present motor vehicle use has affected trail conditions, and inferences drawn from on-trail effects need to be considered in this light.

Finally, use of aerial photography did not allow consideration of how vegetation type influenced patterns of bare ground and effects because of trekkers. Several studies have demonstrated relations between recreational trail use, reductions in native plant species, and increased exotic or noxious plants. For example, it is well established that exotic plantspecies richness is higher along roads and trails (Dale and Weaver, 1974; Tyser and Worley, 1992) and in areas disturbed by off-highway vehicles (Davidson and Fox, 1974) than in other areas.

\section{Management Considerations}

The models presented here indicate that other factors affect vegetative condition along the Trail besides handcart trekking. Circumstantial evidence indicates that motor vehicles have contributed the most to vegetative effects on the Trail.

Handcart trekking had negligable effects on the Trail with differences among trekker-use intensities largely indiscernible. More in-depth relations between trekker visitor-use intensities and vegetative cover along the Trail could be assessed quantitatively but would require further carefully designed data collection for a period of years.

Marginal differences in vegetative cover were apparent among low-use Trail sections when compared with either moderate or high-use sections. However, yearly variation in visitor use and unquantified factors such as motor vehicle volume inhibited our ability to fully assess relations between handcart-trekking intensity and vegetation loss on the Trail.
Estimating the interactive effects of both motor vehicles and handcart trekking on vegetative condition along the Trail is possible but would require data collection coordinated with management of vehicle and trekker use.

Concentrated-use sites such as rest and toilet stops had substantial vegetative loss. Areas where sensitive vegetation (woody-stemmed shrubs, forbs, and so forth), soils, or other features of interest occur need to be identified and managed to preclude future placement of camp, rest, and toilet sites.

Soil type and vegetative-cover composition are correlated. Therefore, vegetative sensitivity to trekker use likely varies among soil types. Detailed assessment of the effects of trekker-use intensities on vegetation and soils is possible but will require further study.

Establishment of permanent monitoring plots for each trail segment would allow long-term monitoring of the status and trends of bare ground and invasive exotic-plant species. Using adaptive management with explicit goals or targets, such plots could be used to determine whether management actions or mitigation practices (revegetation/seeding, control of invasive species, and so forth) are necessary for the longterm sustainability of the Historic Trail.

\section{Summary}

Vegetative condition on and near the Trail can influence the scenic quality of the Trail. The amount of devegetated bare ground present also may influence the quality of visitors' heritage or historical experience while on the Trail. All areas of the Trail on which recent recreational use was permitted were wider than unused trail segments, but there is no evidence that handcart trekking affected trail width. Handcart trekking affected on-trail vegetative cover to a minor degree, with moderate and high trekker-use areas affected slightly more than low-use areas.

Although trail segments having handcart activity contained less vegetation than control areas without trekker activity, effects caused by handcart trekking appeared to be less severe than effects caused by motor vehicle traffic. The contributing effects of motor vehicle use on trail condition restricted our ability to detect effects of handcart trekking on vegetative condition. Concentrated-use areas such as toilet and rest sites also had reduced vegetative cover relative to unused areas. Sections of the Trail where no recreational use had occurred for a period of years demonstrated a gradual vegetative recovery, and this phenomenon needs to be evaluated in light of the desired management condition of this Trail section. Gaining a better understanding of the relations between Mormon handcart trekking and vegetative conditions along the Trail will require studies involving, at a minimum, manipulations of trekker and motor vehicle use levels and, ideally, establishment of long-term monitoring plots to evaluate onsite conditions and trends in bare ground, and other important measures such as invasive exotic plants. 


\section{Acknowledgments}

We thank Craig Bromley, Karina Bryan, Jared Oakleaf, and Sydney Schopke of the BLM Lander Field Office for technical and logistical support and for sharing their onsite knowledge of the study area with us. Ken Henke, Don Simpson, and Andrew Tenny of the BLM Wyoming State office provided financial support for this study and helped with study conceptualization. Primary funding was provided by the U.S. Geological Survey Central Region Interdisciplinary Science Partnerships (CRISP). Additional technical assistance was provided by the Fort Collins Science Center GIS and Remote Sensing Team personnel. Kay Dudek and Collin Talbert of the Arctic Slope Regional Corporation Management Services at the Fort Collins Science Center also assisted with the orthorectification process, and Tim Assal assisted with developing the intial spatial sampling design.

\section{References Cited}

Adams, J.A., Endo, A.S., Stolzy, L.H., Rowlands, P.G., and Johnson, H.B., 1982, Controlled experiments on soil compaction produced by off-road vehicles in the Mojave Desert, California: Journal of Applied Ecology, v. 19, p. 167-175.

Beyer, H.L., 2007, Hawth's analysis tools for ArcGIS: http:// www.spatialecology.com/htools.

Bjorkman, A., 1996, Off road bicycle and hiking trail user interactions-A report to the Wisconsin Natural Resources Board: Eagle, Wisconsin Department of Natural Resources Bureau of Research Report, 124 p.

Bureau of Land Management, 2004, Environmental assessment for the proposed special recreation permit to conduct handcart treks on Bureau of Land Management administered public lands between Sixth Crossing and Rock Creek Hollow: Lander, Wyo., BLM Lander Field Office report, $90 \mathrm{p}$.

Bureau of Land Management, 2005, Finding of no significant impact and decision of record for the proposed special recreation permit to conduct handcart treks on Bureau of Land Management administered public lands between Sixth Crossing and Rock Creek Hollow: Lander, Wyo., BLM Lander Field Office report, $26 \mathrm{p}$.

Dale, D., and Weaver, T., 1974, Trampling effects on vegetation of the trail corridors of north Rocky Mountain forests: Journal of Applied Ecology, v. 11, p. 767-772.

Davidson, E.D., and Fox, M., 1974, Effects of off-road motorcycle activity on Mojave Desert vegetation and soil: Madroño, v. 22, p. 381-390.
Environmental Systems Research Institute, 2006, ArcGIS Release 9.2 [software]: Redlands, Calif., Environmental Systems Research Institute, 1999-2007.

ERDAS Imagine, 2006, ERDAS Imagine Professional, Version 9.1: Norcross, Ga., Leica Geosystems, Inc.

Haines, A.L., 1981, Historic sites along the Oregon Trail: Gerald, Mo., Patrice Press, 439 p.

Hosmer, D.W., and Lemeshow, S., 2000, Applied logistic regression, 2 d ed.: New York, John Wiley \& Sons, 373 p.

Image Processing Software, Inc., 2007, OrthoMapperSoftcopy Photogrammetric Software for the GIS, Natural Resources and Engineering Professionals: Madison, Wis., Image Processing Software, Inc., 152 p.

Jordan, J., 2000, Ecological impacts of recreational use of trails-A literature review: Cold Spring Harbor, N.Y., The Nature Conservancy, http://conserveonline.org/ docs/2000/11/Trails.doc, accessed November 7, 2007.

Kutiel, P., Eden, E., and Zhevelev, Y., 2000, Effect of experimental trampling and off-road motorcycle traffic on soil and vegetation of stabilized coastal dunes, Israel: Environmental Conservation, v. 27, p. 14-23.

Love, J.D., and Christiansen, A.C., 1985, Geologic map of Wyoming: U.S. Geological Survey Special Geologic Map, scale 1:500,000.

Lovich, J.E., and Bainbridge, D., 1999, Anthropogenic degradation of the southern California desert ecosystem and prospects for natural recovery and restoration: Environmental Management, v. 24, p. 309-326.

National Park Service, 1999, Comprehensive Management and Use Plan and Final Environmental Impact Statement for the California National Historic Trail and Pony Express National Historic Trail; and the Management and Use Plan Update and Final Environmental Impact Statement for the Oregon National Historic Trail and the Mormon Pioneer National Historic Trail: Lakewood, Colo., National Park Service, $371 \mathrm{p}$.

National Park Service, 2007, Mormon Pioneer National Historic Trail-History and culture: Interpretive Site Bulletin, Salt Lake City, Utah, 2 p.

Ouren, D.S., Haas, Christopher, Melcher, C.P., Stewart, S.C., Ponds, P.D., Sexton, N.R., Burris, Lucy, Fancher, Tammy, and Bowen, Z.H., 2007, Environmental effects of off-highway vehicles on Bureau of Land Management lands-A literature synthesis, annotated bibliographies, extensive bibliographies, and Internet resources: U.S. Geological Survey Open-File Report 2007-1353, 225 p. 
Roberts, S., 1989, Wyoming geomaps: Laramie, Wyo., Geological Survey of Wyoming, $42 \mathrm{p}$.

StataCorp, 2007, Release 10: College Station, Texas.

Tyser, R.W., and Worley, C.A., 1992, Alien flora in grasslands adjacent to road and trail corridors in Glacier National Park, Montana (U.S.A.): Conservation Biology, v. 6, p. 253-262.

Webb, R.H., 1983, Compaction of desert soils by off-road vehicles, in Webb, R.H., and Wilshire, H.G., eds., Environmental effects of off-road vehicles-Impacts and management in arid regions: New York, Springer-Verlag, p. 50-79. 


\section{Appendixes}




\section{Appendix 1. Aerial Photograph Acquisition and Ground-Control GPS Details}

Number of flight path segments: 20

Approximate aerial coverage of each photographic frame: $900 \mathrm{~m}$ x $900 \mathrm{~m}$.

Overflight elevation for photography: $610 \mathrm{~m}$ above ground surface.

Camera, lens, aperture information are reported in Appendix 2.

Photograph scale and resolution: 1:3,960 and a spatial resolution of $60.1 \mathrm{~mm}$. At this scale, National Mapping Accuracy Standards require error of about $1 / 50^{\text {th }}$ of an inch, or in this case $2.0 \mathrm{~m}$.

Original color positives were scanned and converted into digital format by the contractor at an image resolution of 1,814 dots per inch (DPI). 


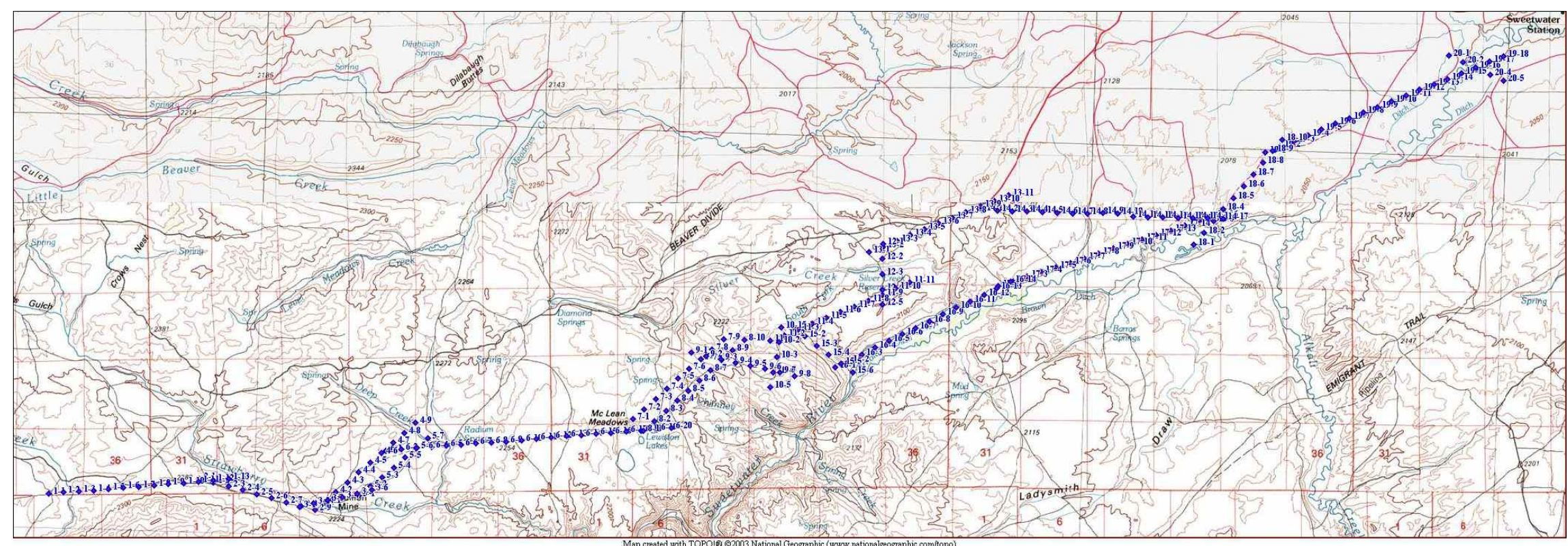

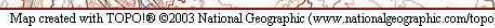




\section{Ground-Control Point and OPUS Solution Information}

Ground-control targets were distributed evenly along the flightlines to facilitate tying points in the aerial photos to realworld coordinates and assess accuracy of the orthorectified photos. To accurately record the position of the ground-control targets, a real-time kinematic (RTK) global positioning system (GPS) was used. The GPS system used in this survey consisted of a stationary base station and a roving receiver. The reference frame chosen for this survey was the World Geodetic System 1984 (WGS84), and coordinates were recorded as geographic latitude and longitude.

A Leica GRX1200 Pro ${ }^{\circledR}$ receiver was used as a base station at eight sites along the Trail. The base station receiver was stationary and recorded satellite information at a 30-second sampling rate, which was later processed to calculate a more accurate base station position. A Pacific Crest Positioning Data Link PDL ${ }^{\circledR}$ radio transmitter was attached to the base station that broadcasts real-time GPS signal corrections to the roving GPS receiver. The logged GRX1200 base station data were converted to a standard Receiver Independent Exchange format (RINEX) and submitted to the National Geodetic Survey's Online Positioning User Service (OPUS) to more accurately define the base station position. The OPUS solution was referenced to the International Terrestrial Reference Frame of 2000 (ITRF00), which is equivalent at the centimeter scale to WGS84. The OPUS solutions and corrections for the base stations are given in Appendix 1.

The OPUS solution provides an orthometric elevation relative to the North American Vertical Datum of 1988 (NAVD88) by subtracting the geoid99 separation from the North American Datum of 1983 (NAD83) ellipsoid height. The WGS84 ellipsoid height was referenced to NAVD88 by calculating the geoid separation at the base station by first subtracting the NAVD88 orthometric height of the NAD83 reference frame from the WGS84 ellipsoid height, and then subtracting this geoid separation value from each WGS84 ellipsoid height recorded. The WGS84 longitude and latitude values were converted to Universal Transverse Mercator (UTM) coordinates in Zone 12 North using the GRS 1980 ellipsoid with the NAD83 datum transform. After the conversion of the coordinates to UTM, the OPUS corrections were applied to the base station and rover data, resulting in positional information with centimeter-scale accuracy (Appendix 2).

The roving RTK GPS receiver, a Leica GX1230 ${ }^{\circledR}$, was used to survey the location of 47 ground-control targets evenly spaced along the trail. The roving GPS receiver logged data at $1 \mathrm{~Hz}$ and has a horizontal and vertical accuracy of approximately 2 centimeters.

Comparison of Ground-Control Target GPS Coordinates to Orthorectified Aerial Photographs

\begin{tabular}{lcccccc}
\hline & Count & Minimum & Maximum & Sum & Mean & $\begin{array}{c}\text { Standard } \\
\text { deviation }\end{array}$ \\
\hline Reference Orthophotos & 41 & 1.99 & 6.47 & 141.63 & 3.45 & 1.10 \\
2006 Aerial Photography & 42 & 1.36 & 5.86 & 130.22 & 3.10 & 1.22 \\
Count = Number of pairs of points & & & & \\
Minimum = Minimum distance between pairs of points & \\
Maximum = Maximum distance between pairs of points \\
Sum = Sum of distances between the pairs of points \\
Mean = Average distance between the pairs of points \\
Standard Deviation = One standard deviation of the distance between pairs of points
\end{tabular}

NOTE: Reference Orthophotos (National Agriculture Imagery Program - NAIP) were acquired in late July, August, and early September of 2006. Thirty-seven of forty-two field markers from the GPS survey were visible in the NAIP photography, four other points were located with reference to surrounding features, and one point could not be identified. 
OPUS Solution Information.

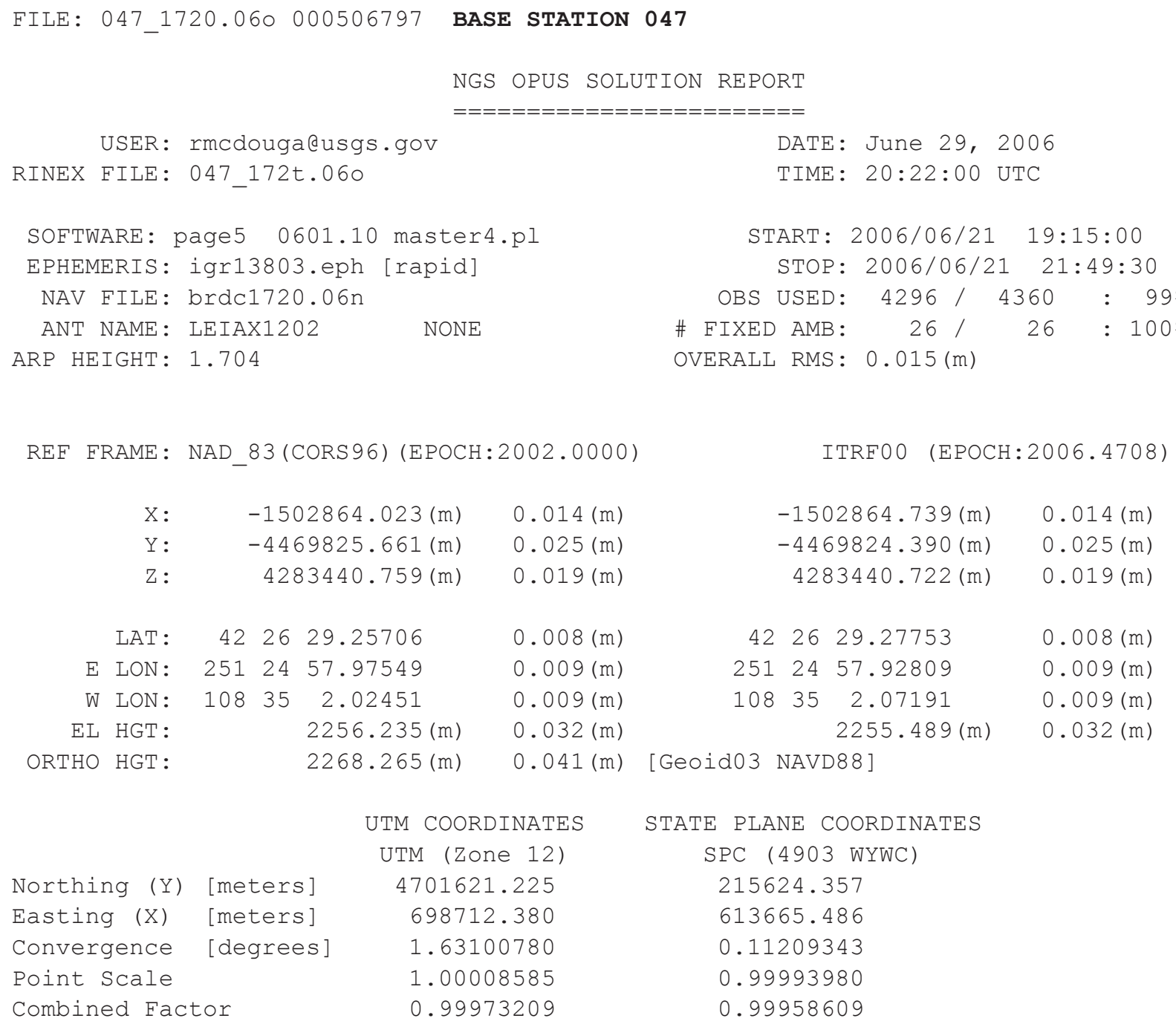

US NATIONAL GRID DESIGNATOR: 12TXN9871201621 (NAD 83)

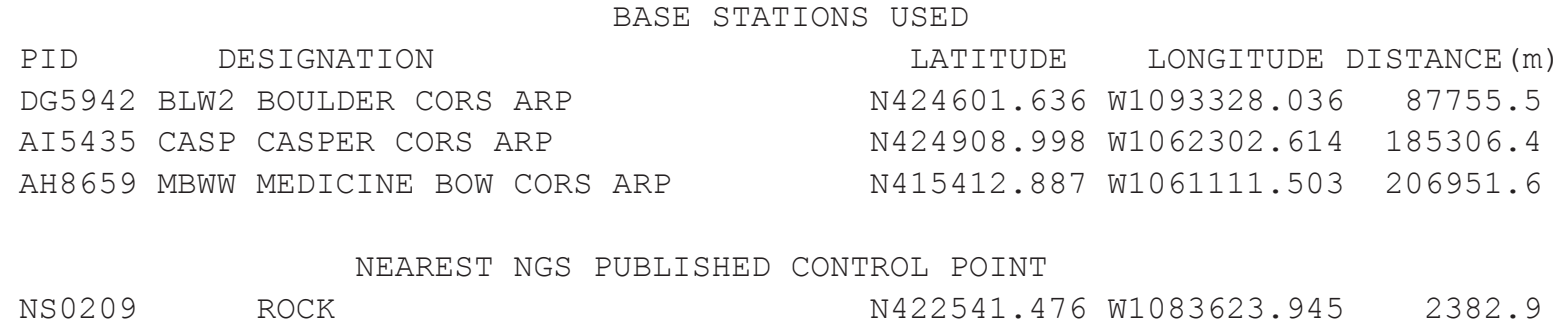




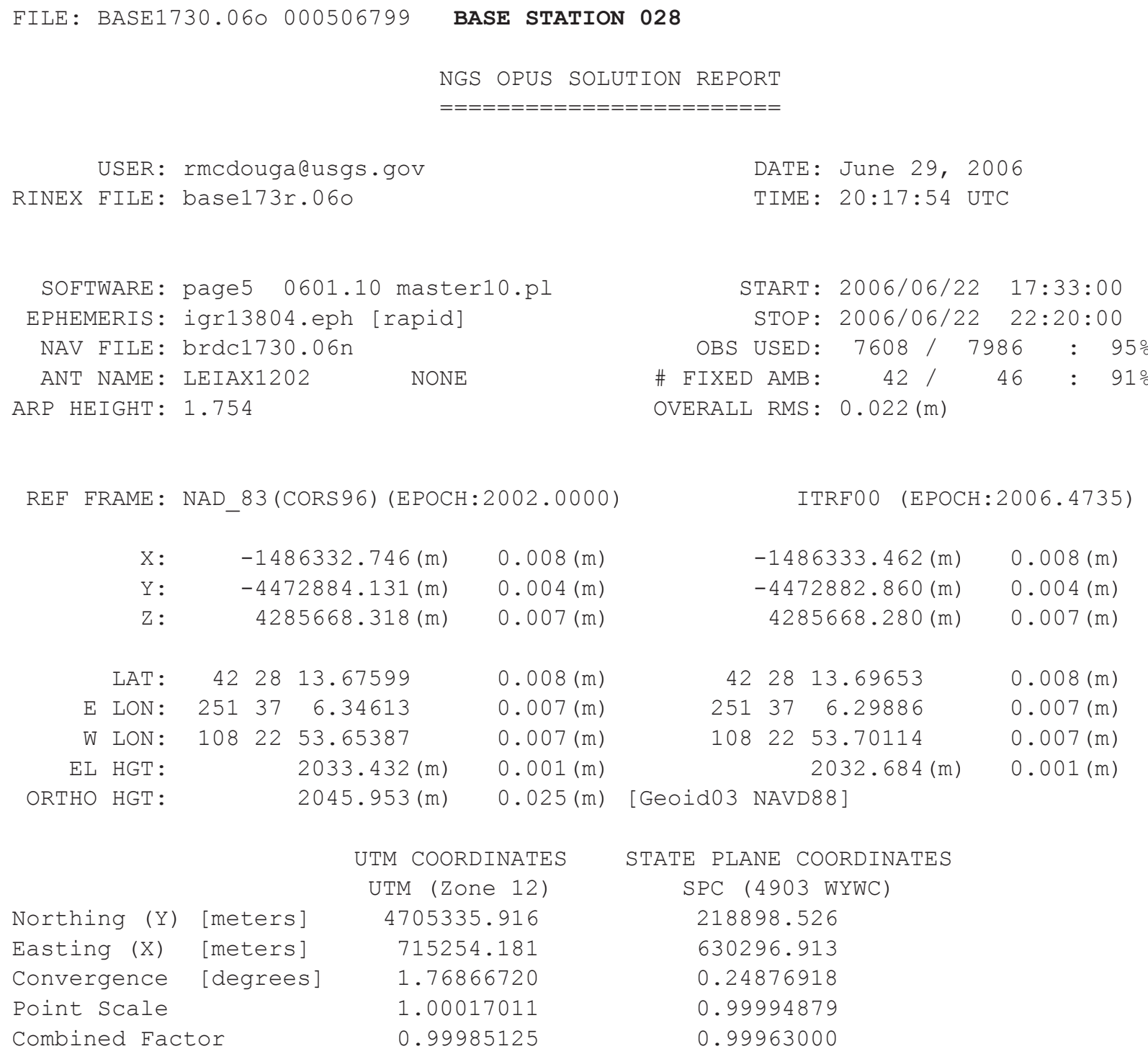

US NATIONAL GRID DESIGNATOR: 12TYN1525405336 (NAD 83)

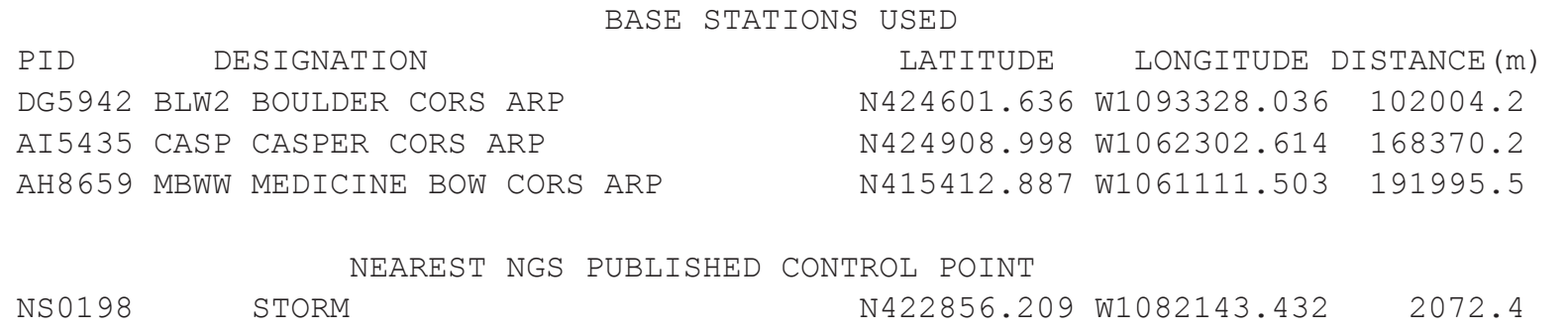


FILE: BASE1740.060 $000506802 \quad$ BASE STATION 005

NGS OPUS SOLUTION REPORT

USER: rmcdouga@usgs.gov

RINEX FILE: base174p.06o
DATE: June 29, 2006

TIME: $20: 28: 36 \mathrm{UTC}$

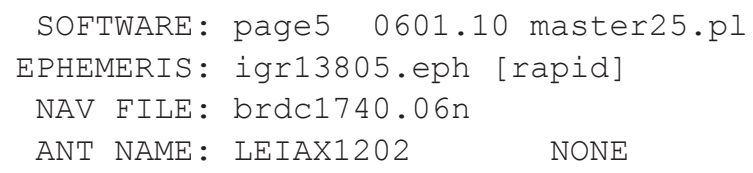

[

STATE PLANE COORDINATES

SPC (4903 WYWC)

224637.469

641761.301

0.34351979

0.99995895

0.99964517

Easting (X) [meters] 726565.024

Convergence [degrees] 1.86500913

1.00023160

0.99991774
ITRF00 (EPOCH:2006.4760)

US NATIONAL GRID DESIGNATOR: 12TYN2656511379 (NAD 83)

BASE STATIONS USED

$\begin{array}{llcrr}\text { PID } & \text { DESIGNATION } & \text { LATITUDE } & \text { LONGITUDE DISTANCE (m) } \\ \text { DG5942 BLW2 BOULDER CORS ARP } & \text { N424601.636 W1093328.036 } & 111355.5 \\ \text { AI5435 CASP CASPER CORS ARP } & \text { N424908.998 W1062302.614 } & 155867.6 \\ \text { AH8659 MBWW MEDICINE BOW CORS ARP } & \text { N415412.887 W1061111.503 } & 183111.0\end{array}$

NS 0161

$\begin{array}{llll}\text { GRAVEL } & \text { N423103.286 W1081437.043 } & 473.1\end{array}$

NEAREST NGS PUBLISHED CONTROL POINT 
FILE: BASE1741.060 000506803 BASE STATION 010

NGS OPUS SOLUTION REPORT

USER: rmcdouga@usgs.gov

RINEX FILE: base174u.06o
DATE: June 29, 2006

TIME: $20: 30: 12$ UTC

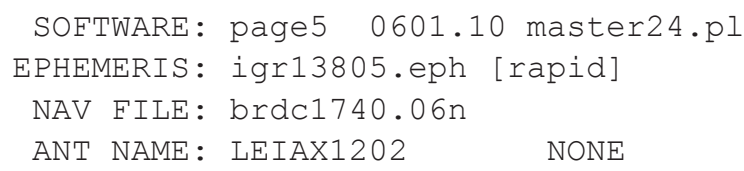

ITRF00 (EPOCH:2006.4764)

$$
\begin{array}{rr}
-1478230.225(\mathrm{~m}) & 0.004(\mathrm{~m}) \\
-4473631.513(\mathrm{~m}) & 0.021(\mathrm{~m}) \\
4287645.087(\mathrm{~m}) & 0.019(\mathrm{~m})
\end{array}
$$

[Geoid03 NAVD88]

$\begin{array}{rrrl}42 & 29 & 41.14876 & 0.003(\mathrm{~m}) \\ 251 & 42 & 53.28343 & 0.003(\mathrm{~m}) \\ 108 & 17 & 6.71657 & 0.003(\mathrm{~m}) \\ & 2012.123(\mathrm{~m}) & 0.028(\mathrm{~m}) \\ \text { M03 NAVD88] } & \end{array}$

STATE PLANE COORDINATES

SPC (4903 WYWC)

221635.731

638208.098

0.31399627

0.99995545

0.99963988

US NATIONAL GRID DESIGNATOR: 12TYN2309208283 (NAD 83)

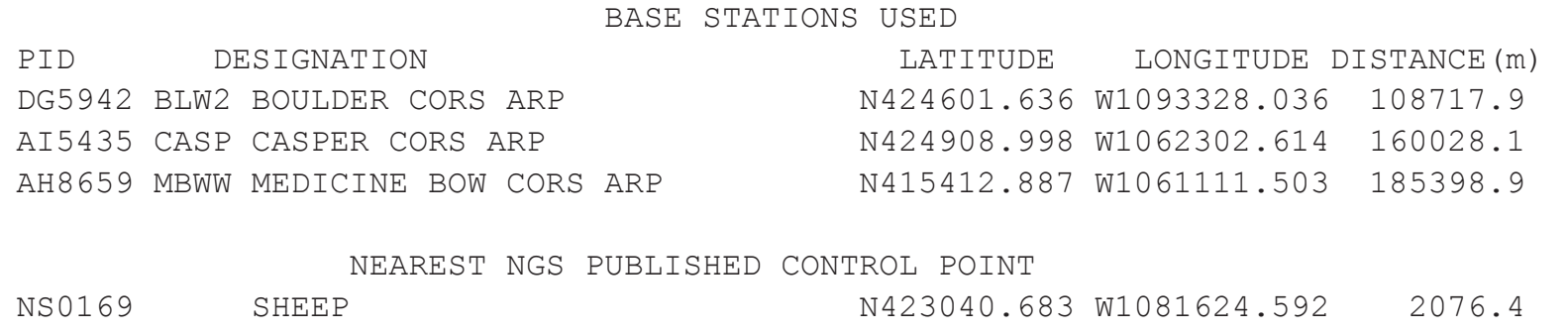




\section{Aerial-Photographic Assessment of the Mormon Pioneer National Historic Trail, Fremont County, Wyoming \\ FILE: 20061750.060000506804 BASE STATION ROCKY RIDGE}

NGS OPUS SOLUTION REPORT

USER: rmcdouga@usgs.gov

RINEX FILE: 2006175 r.06o

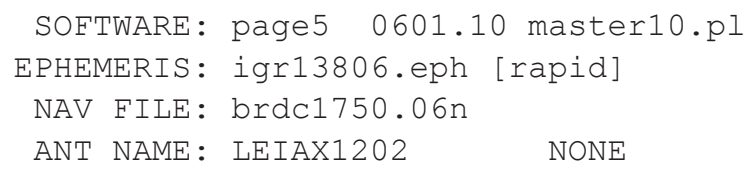

DATE: June 29, 2006 TIME: $20: 23: 36$ UTC

$\begin{array}{rcccc}\text { START: } & 2006 / 06 / 24 & 17: 22: 00 \\ \text { STOP: } & 2006 / 06 / 24 & 20: 48: 30 \\ \text { OBS USED: } & 5673 / & 5801 & : & 98 \% \\ \text { \# FIXED AMB: } & 31 / & 33 & : & 94 \% \\ \text { OVERALL RMS : } & 0.021(\mathrm{~m}) & & & \end{array}$

[Geoid03 NAVD88]
UTM (Zone 12)

Northing (Y) [meters] 4704316.965

Easting (X) [meters] 710421.571

Convergence [degrees] 1.72845806

Point Scale 1.00014480

Combined Factor

0.99979666
STATE PLANE COORDINATES

SPC (4903 WYWC)

218008.289

625440.001

0.20883116

0.99994546

0.99959739

US NATIONAL GRID DESIGNATOR: 12TYN1042204317 (NAD 83)

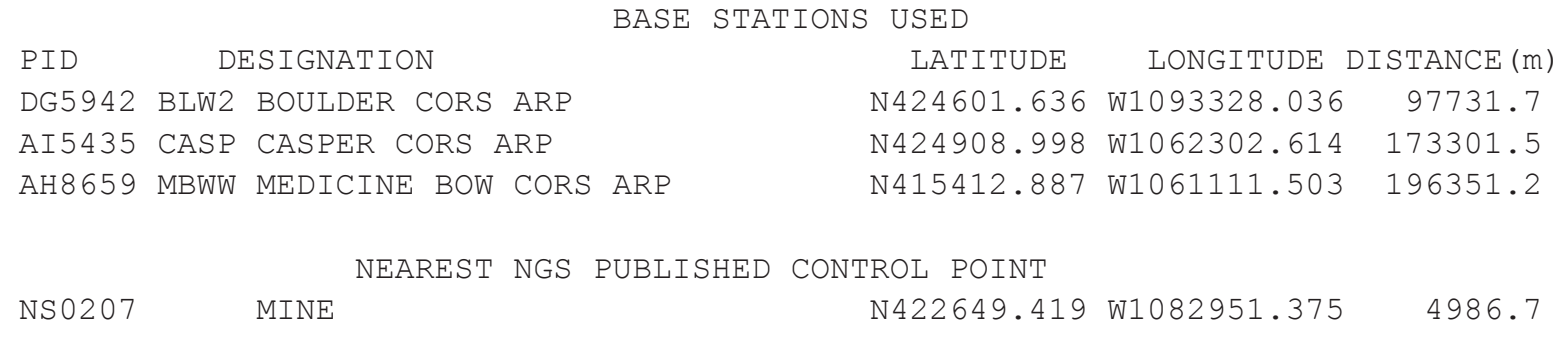


USER: rmcdouga@usgs.gov

RINEX FILE: base176p.06o
DATE: June 29, 2006

TIME: $20: 36: 20$ UTC

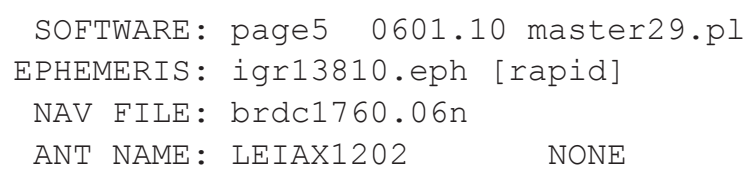

ITRF00 (EPOCH:2006.4814)

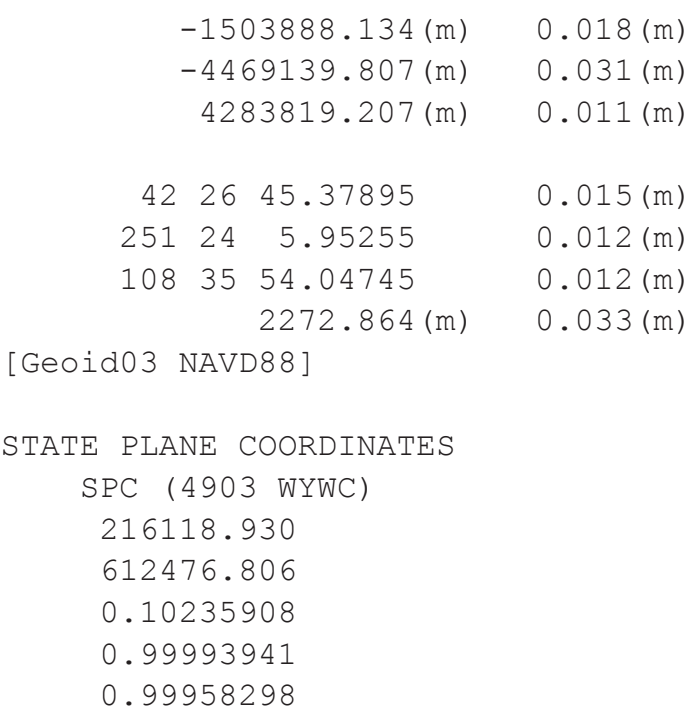

US NATIONAL GRID DESIGNATOR: 12TXN9751102084 (NAD 83)

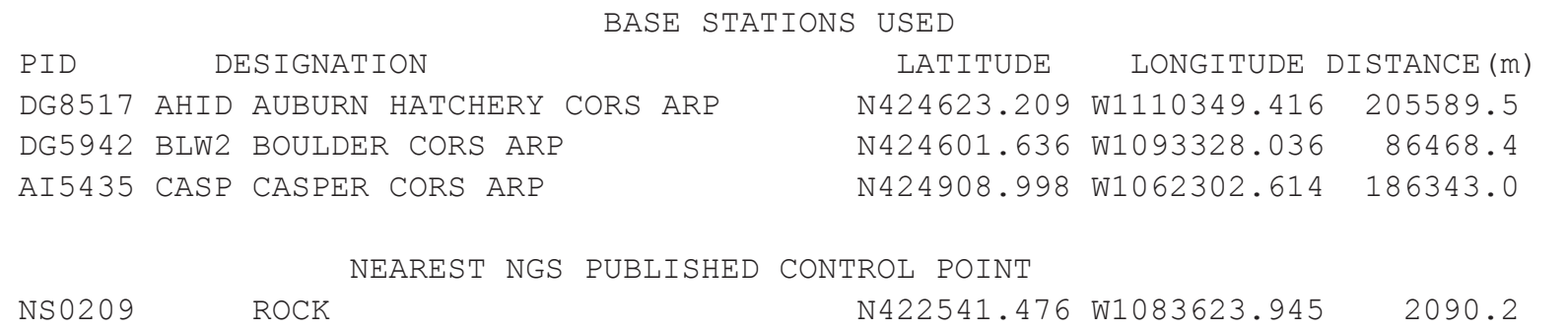




\section{Aerial-Photographic Assessment of the Mormon Pioneer National Historic Trail, Fremont County, Wyoming \\ FILE: BASE1761.060 000506809 BASE STATION 019}

NGS OPUS SOLUTION REPORT

USER: rmcdouga@usgs.gov

RINEX FILE: base176v.06o
DATE: June 29, 2006

TIME: $20: 36: 53$ UTC

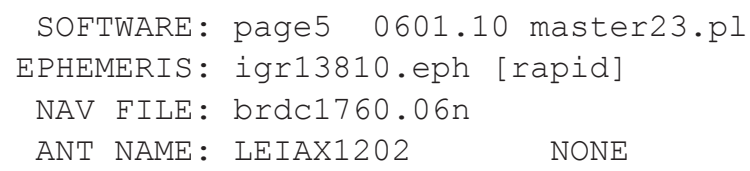

US NATIONAL GRID DESIGNATOR: 12TYN1406605948 (NAD 83)

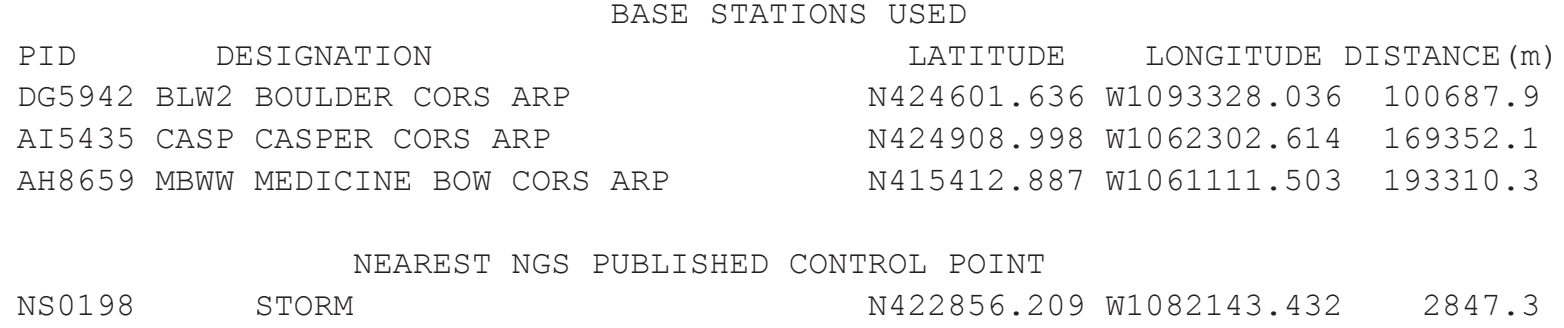


USER: rmcdouga@usgs.gov RINEX FILE: 2006176s.06o
DATE: June 29, 2006

TIME: $20: 31: 33$ UTC

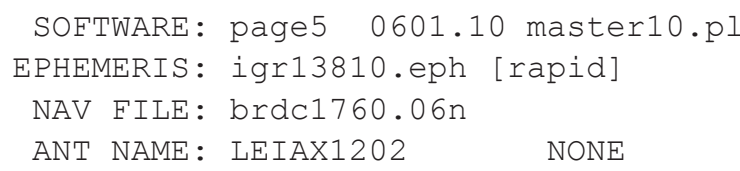

ITRF00 (EPOCH:2006.4817)

US NATIONAL GRID DESIGNATOR: 12TYN0559002597 (NAD 83)

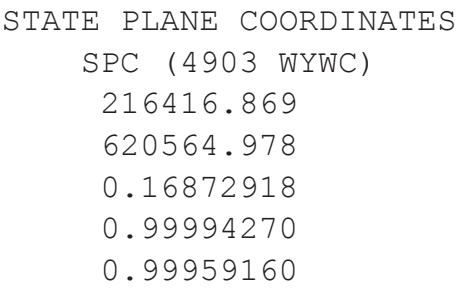

[Geoid03 NAVD88]

$\begin{array}{rrrl}42 & 26 & 54.41516 & 0.026(\mathrm{~m}) \\ 251 & 29 & 59.93649 & 0.004(\mathrm{~m}) \\ 108 & 30 & 0.06351 & 0.004(\mathrm{~m}) \\ & 2238.850(\mathrm{~m}) & 0.058(\mathrm{~m})\end{array}$

BASE STATIONS USED

\begin{tabular}{llrrr} 
PID & \multicolumn{1}{c}{ DESIGNATION } & LATITUDE & LONGITUDE DISTANCE (m) \\
DG5942 BLW2 BOULDER CORS ARP & N424601.636 W1093328.036 & 93771.6 \\
AI5435 CASP CASPER CORS ARP & N424908.998 W1062302.614 & 178419.5 \\
AH8659 MBWW MEDICINE BOW CORS ARP & N415412.887 W1061111.503 & 200547.0
\end{tabular}

NS0207 MINE N422649.419 W1082951.375 250.1 


\section{Appendix 2. Orthorectification and External Orientation Standard Operating Procedures}

\section{Overview of Processing Methods}

The aerial photographs were orthorectified and georeferenced for use as a base for further Geographic Information System (GIS) analysis. The standard operating procedure for orthorectification on this project was developed by personnel from the GIS and Remote Sensing Team, U.S. Geological Survey Fort Collins Science Center, Fort Collins, Colorado. OrthoMapper ${ }^{\circledR}$ software $^{-}$ by Image Processing Software, Inc., was used for the orthorectification process.

Reference control points were taken from the United States Department of Agriculture's (USDA) 2006 National Agricultural Imagery Program (NAIP) data set. The NAIP imagery has a 1-meter ground-sample distance (GSD) with a horizontal accuracy that matches within $5 \mathrm{~m}$ of a reference orthophoto image. For each unregistered photograph, a minimum of 13 control points were selected. Control points were evenly distributed throughout the image, but the placement of points near the corners and edges and near fiducial marks on the photographs was particularly important to correctly position the images. A 30-m resolution USGS digital elevation model (DEM) was used to correct terrain distortion in the orthorectification process.

After the reference control points were chosen and an acceptable root mean square (RMS) of less than 2.0 was achieved, tie points were selected from each digital aerial photograph to increase the accuracy of the mosaicking process. The number of tie points on each photograph ranged form 9 to 35 . Tie points are used to snap equivalent features together between adjacent flight paths during the mosaic process.

\section{Orthorectification Results for the Mormon Pioneer National Historic Trails Project}

Internal (fiducial) orientation RMS values for columns exceeded 0.50 in only seven instances where the values were: 0.52 , $0.52,0.54,0.54,0.56,0.57,0.77$. Row values never exceeded 0.50 .

External (control-point) orientation RMS values for columns ranged from 6.32 to 60.65. External orientation RMS values for rows ranged from 6.99 to 55.29. Second-order RMS for all aerial photos ranged from 0.5 to 3.1. The number of control points per aerial photo ranged from 18 to 43. The map projection for this project is Universal Transverse Mercator (UTM), Zone 12 North, using the North American Datum for 1983 (NAD83).

Comparison of GPS survey points between USGS NAIP* reference orthophotos and June 2006 orthorectified aerial photography. Units are in meters.

\begin{tabular}{|c|c|c|c|c|c|c|}
\hline & Count $^{1}$ & Minimum $^{2}$ & Maximum $^{3}$ & Sum $^{4}$ & $\operatorname{Mean}^{5}$ & $\begin{array}{l}\text { Standard } \\
\text { deviation }^{6}\end{array}$ \\
\hline Reference Orthophotos & 41 & 1.99 & 6.47 & 141.63 & 3.45 & 1.10 \\
\hline 2006 Aerial Photography & 42 & 1.36 & 5.86 & 130.22 & 3.10 & 1.22 \\
\hline
\end{tabular}

${ }^{1}=$ number of pairs of points.

${ }^{2}=$ minimum distance between pairs of points.

${ }^{3}=$ maximum distance between pairs of points.

${ }^{4}=$ sum of distances between the pairs of points.

${ }^{5}=$ average distance between the pairs of points.

${ }^{6}=1$ Standard deviation.

"Reference Orthophotos (National Agriculture Imagery Program - NAIP) were acquired in late July, August, and early September of 2006. Thirty-seven of 42 field markers from the GPS survey were visible in the NAIP photography, 4 other points were located with reference to surrounding features, and 1 point could not be identified. 
Coordinates of field positions of ground-control points.

\begin{tabular}{|c|c|c|c|c|c|c|c|c|c|c|c|}
\hline Survey Point & $\begin{array}{c}\text { lat } \\
\text { degrees }\end{array}$ & $\begin{array}{c}\text { lat } \\
\text { minutes }\end{array}$ & $\begin{array}{c}\text { lat } \\
\text { seconds }\end{array}$ & $\begin{array}{c}\text { long } \\
\text { degrees }\end{array}$ & $\begin{array}{c}\text { long } \\
\text { minutes }\end{array}$ & $\begin{array}{c}\text { long } \\
\text { seconds }\end{array}$ & $\begin{array}{l}\text { latitude } \\
\text { dec deg }\end{array}$ & $\begin{array}{l}\text { longitude } \\
\text { dec deg }\end{array}$ & $\begin{array}{c}\text { UTM } \\
\text { easting }\end{array}$ & $\begin{array}{c}\text { UTM } \\
\text { northing }\end{array}$ & $\begin{array}{c}\text { Elevation } \\
\text { (m) }\end{array}$ \\
\hline BASE005 & 42 & 31 & 17.79952 & -108 & 14 & 30.32733 & 42.52161098 & -108.2417576 & 726563.6955 & 4711380.034 & 2003.0336 \\
\hline МНСТ001 & 42 & 31 & 41.77624 & -108 & 12 & 5.60883 & 42.52827118 & -108.201558 & 729841.5682 & 4712227.953 & 2000.774 \\
\hline МНСТ002 & 42 & 31 & 29.38108 & -108 & 12 & 15.47894 & 42.52482808 & -108.2042997 & 729628.9922 & 4711838.157 & 1997.3655 \\
\hline МНСТ003 & 42 & 31 & 50.64658 & -108 & 12 & 42.9527 & 42.53073516 & -108.2119313 & 728980.522 & 4712473.479 & 1988.998 \\
\hline МНСТ004 & 42 & 31 & 21.06842 & -108 & 13 & 29.00178 & 42.52251901 & -108.2247227 & 727959.805 & 4711526.565 & 1994.4856 \\
\hline МНСТ006 & 42 & 30 & 44.9388 & -108 & 15 & 27.90625 & 42.512483 & -108.2577517 & 725282.7144 & 4710323.701 & 2026.4055 \\
\hline МНСТ007 & 42 & 30 & 48.30357 & -108 & 16 & 8.54951 & 42.51341766 & -108.2690415 & 724351.8207 & 4710397.534 & 2058.7839 \\
\hline МНСТ008 & 42 & 30 & 21.06277 & -108 & 16 & 33.87571 & 42.50585077 & -108.2760766 & 723800.8543 & 4709538.626 & 2068.266 \\
\hline МНСТ009 & 42 & 29 & 57.07135 & -108 & 17 & 7.80172 & 42.49918649 & -108.2855005 & 723050.2306 & 4708773.711 & 2031.6816 \\
\hline BASE047 & 42 & 26 & 29.27924 & -108 & 35 & 2.04421 & 42.44146646 & -108.5839012 & 698711.9078 & 4701621.881 & 2257.5747 \\
\hline МнСТ042 & 42 & 26 & 22.29931 & -108 & 32 & 11.09986 & 42.43952759 & -108.5364166 & 702623.7433 & 4701518.878 & 2233.1139 \\
\hline МНСТ043 & 42 & 25 & 58.78996 & -108 & 32 & 58.11969 & 42.43299721 & -108.5494777 & 701570.3812 & 4700762.594 & 2220.1219 \\
\hline МНСТ045 & 42 & 25 & 59.02513 & -108 & 33 & 45.69919 & 42.43306254 & -108.5626942 & 700482.9755 & 4700738.54 & 2258.7799 \\
\hline МНСТ046 & 42 & 26 & 16.36193 & -108 & 35 & 4.53421 & 42.43787831 & -108.5845928 & 698666.3661 & 4701221.811 & 2274.1664 \\
\hline МНСТ048 & 42 & 26 & 20.02773 & -108 & 36 & 9.71068 & 42.43889659 & -108.6026974 & 697173.9956 & 4701292.658 & 2259.5111 \\
\hline BASE028 & 42 & 28 & 13.69255 & -108 & 22 & 53.68473 & 42.47047015 & -108.3815791 & 715253.4598 & 4705336.39 & 2034.1605 \\
\hline МНСТ015 & 42 & 29 & 59.83629 & -108 & 21 & 11.0701 & 42.49995453 & -108.353075 & 717494.6206 & 4708683.352 & 2106.7745 \\
\hline МНСТ016 & 42 & 29 & 44.19496 & -108 & 22 & 13.73258 & 42.49560971 & -108.3704813 & 716079.2465 & 4708156.337 & 2081.0362 \\
\hline МНСТ017 & 42 & 29 & 17.85264 & -108 & 23 & 14.79326 & 42.4882924 & -108.3874426 & 714710.4205 & 4707300.655 & 2081.9877 \\
\hline МНСТ018 & 42 & 28 & 44.97831 & -108 & 22 & 51.9265 & 42.47916064 & -108.3810907 & 715263.8043 & 4706302.695 & 2087.9397 \\
\hline МНСТ019 & 42 & 28 & 34.69814 & -108 & 23 & 44.85247 & 42.47630504 & -108.3957924 & 714065.0493 & 4705948.36 & 2100.3374 \\
\hline МНСТ020 & 42 & 28 & 24.40588 & -108 & 24 & 43.04332 & 42.47344608 & -108.4119565 & 712745.9747 & 4705590.193 & 2092.8637 \\
\hline МНСТ022 & 42 & 29 & 22.21457 & -108 & 19 & 31.37507 & 42.48950405 & -108.325382 & 719806.889 & 4707594.282 & 2018.9997 \\
\hline МНСТ023 & 42 & 29 & 12.79375 & -108 & 19 & 7.31193 & 42.48688715 & -108.3186978 & 720365.4415 & 4707321.033 & 2011.2173 \\
\hline МНСТ024 & 42 & 28 & 50.46824 & -108 & 20 & 46.48027 & 42.48068562 & -108.3462445 & 718122.9025 & 4706561.112 & 2017.361 \\
\hline МНСТ025 & 42 & 29 & 1.56067 & -108 & 21 & 1.56603 & 42.48376685 & -108.350435 & 717767.7525 & 4706892.506 & 2033.111 \\
\hline МНСТ026 & 42 & 28 & 34.70784 & -108 & 22 & 0.318 & 42.47630773 & -108.366755 & 716452.0546 & 4706022.384 & 2033.3464 \\
\hline МНСТ027 & 42 & 28 & 39.83661 & -108 & 22 & 1.18247 & 42.47773239 & -108.3669951 & 716427.4041 & 4706179.978 & 2043.403 \\
\hline МНСТ029 & 42 & 27 & 48.03752 & -108 & 23 & 39.13637 & 42.46334376 & -108.3942045 & 714239.8118 & 4704513.043 & 2036.3922 \\
\hline BASE010 & 42 & 29 & 41.13739 & -108 & 17 & 6.70166 & 42.49476039 & -108.2851949 & 723091.0883 & 4708282.999 & 2013.9464 \\
\hline МНСТ011 & 42 & 29 & 45.12659 & -108 & 17 & 58.47595 & 42.4958685 & -108.2995767 & 721905.2547 & 4708368.295 & 2020.6496 \\
\hline МНСТ012 & 42 & 29 & 57.69037 & -108 & 19 & 24.84382 & 42.49935844 & -108.3235677 & 719921.4456 & 4708693.311 & 2051.3244 \\
\hline МНСТ013 & 42 & 29 & 41.42678 & -108 & 19 & 21.76436 & 42.49484077 & -108.3227123 & 720007.5862 & 4708193.847 & 2037.7803 \\
\hline МНСТ014 & 42 & 29 & 41.79501 & -108 & 20 & 42.45095 & 42.49494306 & -108.3451253 & 718165.3124 & 4708147.266 & 2056.7507 \\
\hline МНСТ021 & 42 & 29 & 28.85278 & -108 & 18 & 9.12414 & 42.49134799 & -108.3025345 & 721678.1606 & 4707858.555 & 2007.5371 \\
\hline
\end{tabular}




\begin{tabular}{|c|c|c|c|c|c|c|c|c|c|c|c|}
\hline Survey Point & $\begin{array}{c}\text { lat } \\
\text { degrees }\end{array}$ & $\begin{array}{c}\text { lat } \\
\text { minutes }\end{array}$ & $\begin{array}{c}\text { lat } \\
\text { seconds }\end{array}$ & $\begin{array}{c}\text { long } \\
\text { degrees }\end{array}$ & $\begin{array}{c}\text { long } \\
\text { minutes }\end{array}$ & $\begin{array}{c}\text { long } \\
\text { seconds }\end{array}$ & $\begin{array}{l}\text { latitude } \\
\text { dec deg }\end{array}$ & $\begin{array}{l}\text { longitude } \\
\text { dec deg }\end{array}$ & $\begin{array}{c}\text { UTM } \\
\text { easting }\end{array}$ & $\begin{array}{c}\text { UTM } \\
\text { northing }\end{array}$ & $\begin{array}{c}\text { Elevation } \\
\text { (m) }\end{array}$ \\
\hline ROCKYRIDGE & 42 & 27 & 45.48976 & -108 & 26 & 26.44428 & 42.46263604 & -108.440679 & 710420.9746 & 4704318.092 & 2219.9678 \\
\hline МНСТ031 & 42 & 27 & 39.38279 & -108 & 24 & 55.79556 & 42.46093966 & -108.4154988 & 712497.0938 & 4704192.497 & 2122.529 \\
\hline МHCT032 & 42 & 27 & 45.60794 & -108 & 25 & 52.13177 & 42.46266887 & -108.4311477 & 711204.551 & 4704345.431 & 2184.7241 \\
\hline МНСТ033 & 42 & 28 & 9.89679 & -108 & 26 & 14.39699 & 42.46941578 & -108.4373325 & 710673.3817 & 4705079.276 & 2212.7907 \\
\hline МНСТ034 & 42 & 27 & 31.79586 & -108 & 26 & 45.16157 & 42.45883218 & -108.4458782 & 710006.2043 & 4703882.795 & 2207.0012 \\
\hline МHCT035 & 42 & 27 & 10.66266 & -108 & 27 & 14.86996 & 42.45296185 & -108.4541305 & 709347.2051 & 4703210.508 & 2206.2141 \\
\hline МНCT036 & 42 & 27 & 1.15541 & -108 & 27 & 1.73337 & 42.45032095 & -108.4504815 & 709656.0946 & 4702926.255 & 2201.4665 \\
\hline BASE051 & 42 & 26 & 45.37782 & -108 & 35 & 54.04114 & 42.44593828 & -108.5983448 & 697509.8759 & 4702084.735 & 2277.139 \\
\hline MHCT044NEW & 42 & 25 & 59.55112 & -108 & 32 & 59.77687 & 42.43320864 & -108.549938 & 701531.8388 & 4700784.979 & 2219.0028 \\
\hline МHCT049 & 42 & 26 & 2.90576 & -108 & 37 & 25.97166 & 42.43414049 & -108.623881 & 695446.378 & 4700715.505 & 2244.4198 \\
\hline МHCT050 & 42 & 26 & 25.22796 & -108 & 37 & 28.18555 & 42.4403411 & -108.624496 & 695376.5143 & 4701402.642 & 2233.4081 \\
\hline BASE38 39 & 42 & 26 & 54.46619 & -108 & 30 & 0.04216 & 42.44846283 & -108.5000117 & 705588.8916 & 4702598.69 & 2237.3028 \\
\hline МНСТ037 & 42 & 26 & 58.97865 & -108 & 28 & 35.4996 & 42.44971629 & -108.4765277 & 707516.0933 & 4702795.064 & 2201.9913 \\
\hline МHCT038 & 42 & 26 & 46.40431 & -108 & 29 & 22.89331 & 42.44622342 & -108.4896926 & 706444.9006 & 4702375.07 & 2207.3208 \\
\hline МНСТ039 & 42 & 27 & 0.77271 & -108 & 30 & 31.29624 & 42.45021464 & -108.5086934 & 704869.1913 & 4702772.221 & 2234.5478 \\
\hline МНСТ040 & 42 & 26 & 40.01246 & -108 & 31 & 16.2622 & 42.44444791 & -108.5211839 & 703860.7042 & 4702101.753 & 2230.4423 \\
\hline MHCT041 & 42 & 26 & 55.16762 & -108 & 31 & 41.87169 & 42.44865767 & -108.5282977 & 703262.005 & 4702552.165 & 2258.3124 \\
\hline SECTION34 35 & 42 & 26 & 40.96059 & -108 & 31 & 16.93752 & 42.44471128 & -108.5213715 & 703844.4205 & 4702130.549 & 2231.4773 \\
\hline BASE019 & 42 & 28 & 34.64745 & -108 & 23 & 44.88711 & 42.47629096 & -108.395802 & 714064.3082 & 4705946.773 & 2097.0855 \\
\hline МНСТ030 & 42 & 28 & 2.14151 & -108 & 23 & 2094.0199 & 42.46726153 & -108.9650055 & 667297.9974 & 4703664.206 & 2094.0199 \\
\hline
\end{tabular}




\title{
Standard Operating Procedures
}

\section{9" X 9" Aerial Photograph Orthorectification Analog Camera with a Camera Calibration Report}

\author{
Digital Data Entry Facility \\ GIS and Remote Sensing Team \\ USGS Fort Collins Science Center
}

March 30, 2007

1. All orthorectification projects will be stored in the $\mathrm{N}: \backslash$ Orthorectification directory and named in accordance with the standard $\mathrm{N}: \backslash$ Active naming convention. Before starting a project, review the Orthorectification Project Assignment Sheet for detailed project instructions (refer to separate documentation). Copy the Microsoft Excel template spreadsheet (N:\Ortho\TEMPLATE_Project_ Document_File.xls) to the Doc directory for the project and complete the information for each aerial photo as it is orthorectified.

\section{The Project Document File will be located in the Doc directory for each project and will include the following:}

Scanned Photo Name - Original scanned file name for an aerial photograph.

Uncompressed File Name - Name of uncompressed original file. This will be required for the Wyoming Historic Trails project.

Rotated File Name - If the original scanned file does not have the data strip on the left side, the image must be rotated so that the data strip is on the left side.

Source of DOQQ - Where we obtained the DOQQ.

Original DOQQ - Name of the original DOQQ used for orthorectification.

Source of DEM - Where we obtained the DEM.

Original DEM - Name of the original DEM used for orthorectification.

Fiducial Col RMS - Final value read from the OrthoMapper display.

Fiducial Row RMS - Final value read from the OrthoMapper display.

Control Points - Number of control points used for the final orthorectification.

Control Point Column RMS - Final value read from the OrthoMapper display.

Control Point Row RMS - Final value read from the OrthoMapper display.

GPS Point - A YES entry is required if the control point was acquired with a GPS receiver.

$2^{\text {nd }}$ Order RMS - Final value read from the OrthoMapper display at the time of actual orthorectification.

Orthophoto Product Name - Name of the final orthophoto.

Rectified By - Last name of person performing the orthorectification.

Final Quality Check By - Last name of person performing the final QC on the orthophoto.

Final Quality Check: The final QC check will consist of running ORIENT in OrthoMapper, checking the placement of the control points, and checking the column and row RMS. This will be followed by displaying the output orthophoto on top of the reference orthophoto and checking points in the four corners for offset.

The acceptable offset distance will vary with the project:

Lassen Volcanic National Park - 3 to 5 meters, most should be less than 3 meters.

Wyoming Historic Trails $-3-5$ meters, most should be less than 3 meters.

Diane Schneider will perform the final quality check for Hannah Moyer, Colin Talbert, and Bob Waltermire.

2. Aerial photographs must be scanned at $\bullet 600$ dots per inch (DPI) with the data strip on the left side. The data strip is defined by the frame number. It will be in one corner of the image and in orange, red, or some other color. The title line could be anywhere on the aerial photo and does not have any relations to the data strip. If the aerial photo is already scanned, and the data strip is not on the left side, use IrfanView to rotate the image. For example, if the data strip is on the bottom of the scanned image, use Irfan View to "rotate right" and save as a TIFF file. Irfan View should also be used to determine the scanned resolution of imagery obtained from outside sources. 
Example: The Lassen Volcanic National Park (LAVO) project has the title line on the north side of the aerial photo. The data strip is either on the north side (when the plane is flying south) or on the south side (when the plane is flying north). Refer to Figure A for an example.

3. OrthoMapper (OM) software by Image Processing Software, Inc. will be used for orthorectification. OM may work better if the aerial photo to be orthorectified is converted in OM to a .LAN file using Utilities|File Conversion|Create LAN/DEM from TIF/IMG file. OM will, however, also work by accessing the aerial photo as a TIFF file.

4. The Utilities|File Conversion|Create LAN/DEM from TIF/IMG file also must be used to convert the digital elevation model (DEM) to an OM .DEM file.

The 10-meter USGS DEMs must be used unless only the 30-meter USGS DEMs are available.

\section{Suggested sources for DEM data:}

Seamless Data Distribution System: http://seamless.usgs.gov/

GeoCommunity:

http://data.geocomm.com/

TerraServer

USDA Geospatial Data Gateway http://www.terraserver.com/ http://datagateway.nrcs.usda.gov/

5. The digital orthophoto can be added to OM as a .LAN file. The .LAN file should be created using the OM Utilities|File Conversion|Create LAN/DEM from TIF/IMG file. If OM will not accept the .LAN file (you may see the message that OM could not read the orthophoto when it is entered in a .LAN format) it will accept a .TIFF file. The aerial photos, DEM, orthophoto and all other project files related to the orthorectification process must be stored in the same Area Directory.

The reference orthophoto must be of USGS origin unless another source can be shown to be superior in detail and accuracy. For example, a DOQ with significant amounts of snow cover is likely to be inferior to a DOQ with lesser snow cover. NAIP data may have spatial accuracy equal to or exceeding the USGS DOQs (Stan Wilds , U.S. Geological Survey, personal communication, 2007,) and is likely to be more current.

\section{Suggested sources for $\mathrm{DOQ}$ data:}

Seamless Data Distribution System: http://seamless.usgs.gov/

GeoCommunity:

TerraServer

USDA Geospatial Data Gateway

\section{Suggested source for NAIP data:}

Aerial Photography Field Office: USGS:

http://165.221.201.14/NAIP.html

USGS contacts at EROS Data Center

6. The map projection, datum, and units must be the same for the DOQ and the DEM used in the orthorectification, and for the desired orthorectified aerial photo output.

7. Execute OM and click on the START button. Activate the button for Visual Orientation will be used with this project and enter the orthophoto (as a TIFF) and the DEM (as a .DEM). Coordinates will be entered as meters. If OM will not accept the DEM, reboot the computer.

8. Activate the button for Single Frame Camera. Select the Area Directory that contains the data. Select the first aerial photo to process. OM will create a directory for the aerial photo and store the output orthophoto in that directory. Enter the following as:

Is this a digital camera? No.

Do you have a camera calibration report for this image? Yes.

You must enter the required data from the camera calibration report into OM which will build a camera calibration report file. Refer to Figure B, Parts 1 and 2, to view the correct data to enter into the OM camera calibration report file for the Wyoming Historic Trails Project. Camera- calibration information will be used during the orthorectification process and includes each of the following: Camera 
type and camera number; calibrated focal length ( $\mathrm{mm})$; Calibrated principal point (point of symmetry; in millimeters); Radial lensdistortion parameters $\left(\mathrm{K}_{0}, \mathrm{~K}_{1}, \mathrm{~K}_{2}\right.$, and $\left.\mathrm{K}_{3}\right)$; and all eight fiducials. If the symmetric radial distortion parameters are not listed, they can be calculated in OrthoMapper using the "compute" option and entering the symmetric radial (um) for each field angle or equivalent average $\mathrm{D}_{\mathrm{c}}$ values (um) (Donald Moe, EROS Data Center).

If the OM camera calibration report file already exists on the computer, you can access that file. For example, for the LAVO project the name of the file is LAVO Camera Calibration File.

9. OM will prompt Do you wish to orient the image next? Enter Yes to start the internal orientation process. Select the proper Project Name (.pj file) under the Area Directory. Windows will appear to allow entry of the eight fiducials. Refer to Figure C for the placement of fiducials in relation to the data strip. In the right window, right-click to zoom in to a fiducial. In the left window shift leftclick to zoom in, and right-click in the left window to place the fiducial point. When placing the first fiducial point, the left window will disappear. Click OK in the Select window. The Select window will disappear and the left window will re-appear.

Zoom keys in OrthoMapper: $\quad$ Shift or Alt right-click - Zoom out

Shift or Alt left-click - Zoom in

Accuracy Requirements for Fiducials:

The RMS Difference displayed in the upper right corner must read as follows before accepting all eight fiducials:

$$
\text { Cols } \quad 0.50
$$

Rows $\bullet 0.50$

Also check the column and row values for each fiducial. These should all be close to 0.50 . If any are closer to 1.0 check the fiducial placement. It may be necessary to delete and re-enter one or more fiducials. Click on Save and Finished when the fiducial placement is completed.

For the second and succeeding aerial photos click on Auto Placement, enter fiducials 1 and 2, and most or all of the other fiducials will be added automatically. The auto placement is not always precise, and the fiducials may have to be deleted and replaced, or added.

10. OM will automatically display the window to start the Visual (External) Orientation which involves placing control points on the aerial photo to be orthorectified and the orthophoto. The Visual Orientation Menu will list the aerial photo, DEM, and reference orthophoto to be used in the orthorectification. Check to be sure these are correct and add or delete as necessary.

Enter the following correctly to ensure proper orientation of the aerial photo during the orthorectification process:

Direction of Top of Image - Based on the orientation of the aerial photo you are going to orthorectify, enter the direction of the top of the image. For the LAVO project the top will be WEST or EAST (after rotating the image so that the data strip is on the left side).

Flight Direction - This is the direction the aircraft was flying while acquiring the aerial photography. For LAVO the correct entry is NORTH-SOUTH.

Do not check Manual Entry of Control Points.

After pressing $\mathbf{O K}$, three new windows will appear. To display high-resolution images for locating control points, right click in each of the windows that contain an image.

11. The first two control points must be located at opposite corners of the aerial photo to allow the software to approximately project the aerial photo so that control points can be readily located on the reference orthophoto. By first identifying the control point on the aerial photo (and second on the reference orthophoto) it is possible to override the automatic suggested location. After placing the control point in the aerial photo and the reference orthophoto, click on the Measure Point button to measure the coordinates. Each aerial photo must have a minimum of $\mathbf{1 3}$ control points. Occasionally click on the Save button to save work because the OM does have a tendency to lock-up.

12. Control points must be evenly distributed throughout the image, but the edge control points are especially important. Control points must be placed as close to the fiducials as possible. Refer to the Control Point Placement Guide in Figure D. Edge control points must be selected to maximize the number of control points that can be used on each of the overlapping aerial photos. These need not all be equivalent on adjacent aerial photos, but if they are equivalent it will produce a higher quality mosaic. For the Mormon Pioneer National Historic Trails Project, have at least three control points close to the Trail and spread across the aerial photo. 
13. Control points should be located on objects small enough that the data entry specialist (DES) must zoom in to see the object. Small shrubs, rocks, and other precisely identifiable ground features should be used. Control points should not be located on large objects lacking detail such as trees because it is unlikely the control point can be located precisely on the aerial photo and the reference orthophoto.

14. If the DES is certain a control point is accurately matched between the aerial photo being orthorectified and the reference orthophoto, the RMS error for the control point should be acceptable. The following is a guideline for acceptable error values for control point selection (modified from the OM manual). The data for the LAVO and Wyoming Historic Trails projects are given as examples. The following is used to calculate the number of pixels equivalent to 1-meter error and, therefore, the guide to acceptable RMS:

\section{LAVO Example:}

Aerial photo scale: $1: 15,840$

Aerial photo scanned at: 600 DPI

$15,840 " / 39.37 "$ per $\mathrm{m}=402 \mathrm{~m}(1$ " on the aerial photo $=402 \mathrm{~m}$ on the ground $)$

$402 \mathrm{~m}$ per inch / $600 \mathrm{DPI}=0.67$ meters per pixel (size of a pixel in the aerial photo)

$1 / 0.67=1.5$ pixels in the aerial photo are equivalent to $1 \mathrm{~m}$ onsite

RMS of 1.50 represents a 1.0-meter error.

RMS of 2.25 represents a 1.5 -meter error.

RMS of 3.00 represents a 2.0-meter error.

The objective is to minimize the RMS error and have a good fit to the reference orthophoto. We will strive for an RMS $\leq 2.0$. National Map Accuracy Standards require error no more than 1/50 inch at the specified scale. For example, for a 1:15,840-scale aerial photo displayed at that scale, the maximum acceptable error is 8 meters. When the orthorectified aerial photo is compared with the referenced orthophoto, the offset between identical features must not exceed 8 meters. The error should actually be less than 8 meters, because there is some error in the referenced orthophoto. Feature displacement must not exceed 5.0 meters but displacement of $<3.0$ meters should be the norm.

\section{Wyoming Historic Trails Example:}

Aerial photo scale: $1: 3,960$

Aerial photo scanned at: 1814 DPI

3,960 " / 39.37" per $\mathrm{m}=100.5842 \mathrm{~m}(1$ " on the aerial photo $=100.5842 \mathrm{~m}$ onsite $)$

$100.5842 \mathrm{~m}$ per inch / $1814 \mathrm{DPI}=0.055$ meters per pixel (size of a pixel in the aerial photo)

$1 / 0.055=18.03$ pixels in the aerial photo are equivalent to $1 \mathrm{~m}$ on the ground

RMS of 18.0 represents a 1.0-meter error.

RMS of 27.0 represents a 1.5 -meter error.

RMS of 36.1 represents a 2.0 meter error.

National Map Accuracy Standards require error no more than 1/50 inch at the specified scale. For example, for a 1:3,960-scale aerial photo displayed at that scale, the maximum acceptable error is 2.0 meters. When the orthorectified aerial photo is compared with the referenced orthophoto, the offset between identical features should not exceed 2.0 meters. The error should actually be less than 2.0 meters, because there is some error in the referenced orthophoto. Our target is feature displacement $\leq \mathbf{2 . 0}$ meters. We may need to accept a higher displacement value because we will be using a 1-meter DOQ.

15. Enter tie points when enough control points have been added and the control point RMS is acceptable (refer to Figure E). Tie points are used to snap equivalent features together during the mosaic process. Tie points are located in the magenta boxes only if there are adjacent strips of aerial photography (one side or both sides). Tie points in the green boxes tie together adjacent aerial photos along the flight path. Tie points must be located in a line perpendicular to the direction of the airplane's flight path (green boxes) and parallel to adjacent flight paths (magenta boxes). One point must be located in the ends of each box that overlap adjacent aerial photos (two points per box). A tie point is any sharp, well-defined point and is located only on the aerial photo, not on the orthophoto. A tie point can even be the corner of a farm field.

16. When the Visual (External) Orientation and the location of tie points are completed, click on the ORTHO button on the main OM menu and the Select Output Parameters for Orthophoto dialog will appear. Confirm all input and be sure to turn on Use Second Order Polynomial. The Standard Deviation for the Second Order Polynomial must be $\leq \mathbf{2 . 0}$ for an aerial photo scanned at 
600 DPI and $\leq \mathbf{2 7 . 0}$ for an aerial photo scanned at 1814 DPI. The orthophoto created by this process will be stored in the Area Directory and will have_ORTHO.TIF appended to the name of the source aerial photo.

17. After an aerial photo is orthorectified, it must be displayed over the base orthophoto and "blend", "swipe", or "flicker" used to check the accuracy. The center of the output orthophoto and the four edges must be checked. The edges are likely to have the highest error. Feature displacement must not exceed 5.0 meters but displacement of $<3.0$ meters should be the norm. These limits will be dependent on the quality of the reference DOQ and the resolution of the scanned aerial photo.

18. The following process must be followed if the DES determines that any of these standard operating procedures must be altered for any aerial photo.

A. The DES must provide brief and thorough written documentation to the manager of the Digital Data Entry Facility (DDEF) defining the aerial photo in question, the nature of the problem, why the standard operating procedures should be altered, and the proposed alternative methodology. The Alternative to SOP for Orthorectification form will be used (refer to Figure F).

B. The manager of the DDEF will review the Alternative to SOP for Orthorectification form, view the aerial photo in question, and discuss procedures with the DES.

C. The DDEF manager will sign the Alternative to SOP for Orthorectification form if approval of alternative methods is warranted.

D. If the DES's request is approved, the signed Alternative to SOP for Orthorectification form will be incorporated into the metadata for the project and filed in the project folder for future reference. 
A scanned aerial photograph showing the orientation of the title line and the frame number.

Title line:

Interpretation:

\author{
8-8-04 USDA-F 16615060 1004-75 \\ Acquisition date: $8-8-04$ \\ Flown for: USDA-F (Forest Service) \\ Scale: $16(=1: 15,840)$ \\ Project number: 615060 \\ Roll-Exposure: 1004-75
}

For this project, the title line indicates the north side of the aerial photo.

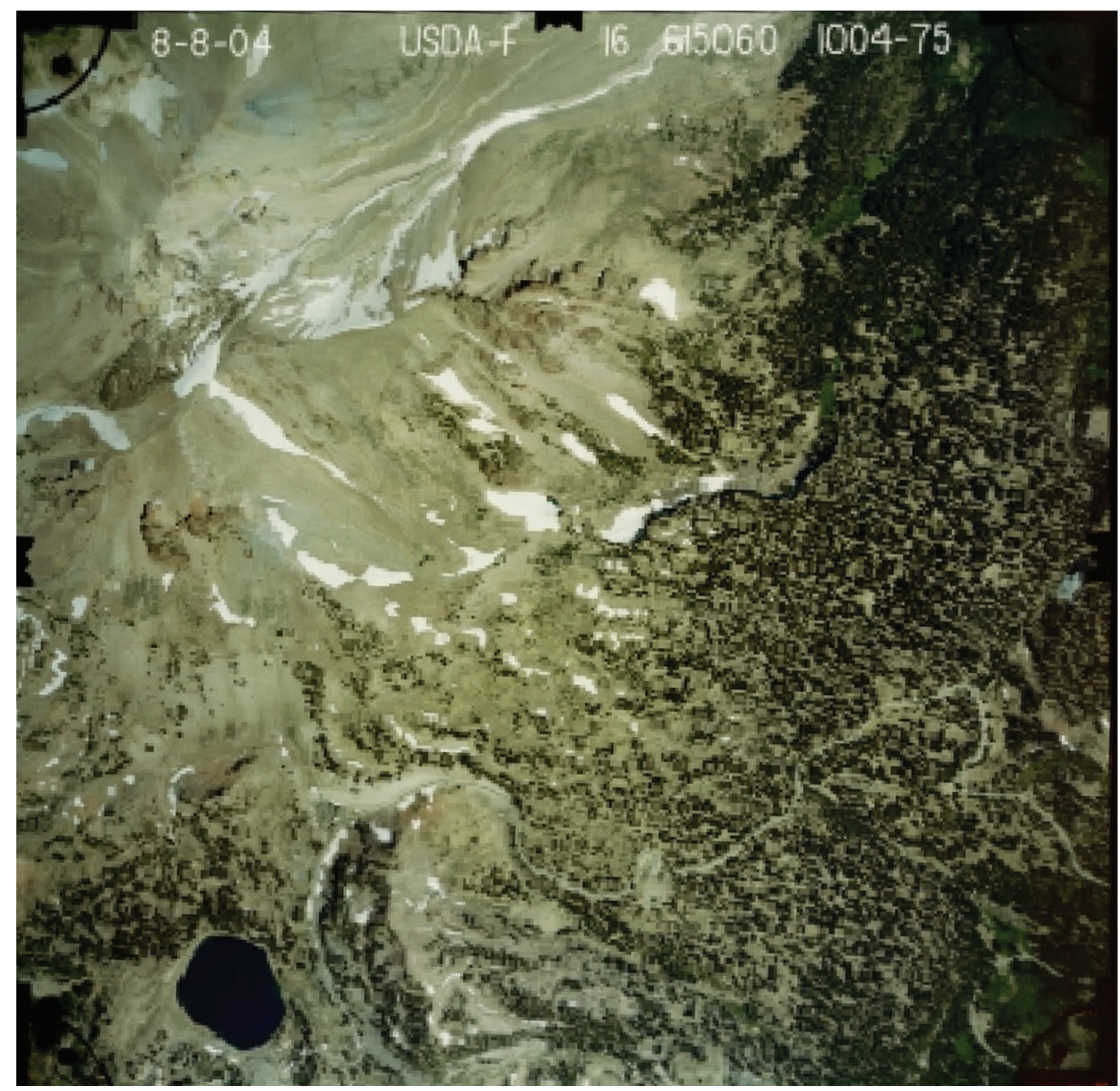

Date Strip: The edge of the aerial photo with the frame number. Example: 342. 


\title{
Aerial Photography Camera Calibration Report for the Mormon Pioneer National Historic Trails project.
}

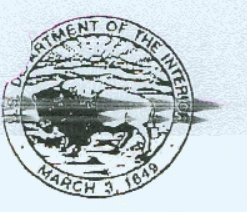

\section{United States Department of the Interior}

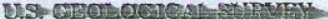 \\ Rcston, Virginia 20192 \\ REPORT OF CALIBHATION \\ of Aerlal Mapping Camera
}

December 17,2004

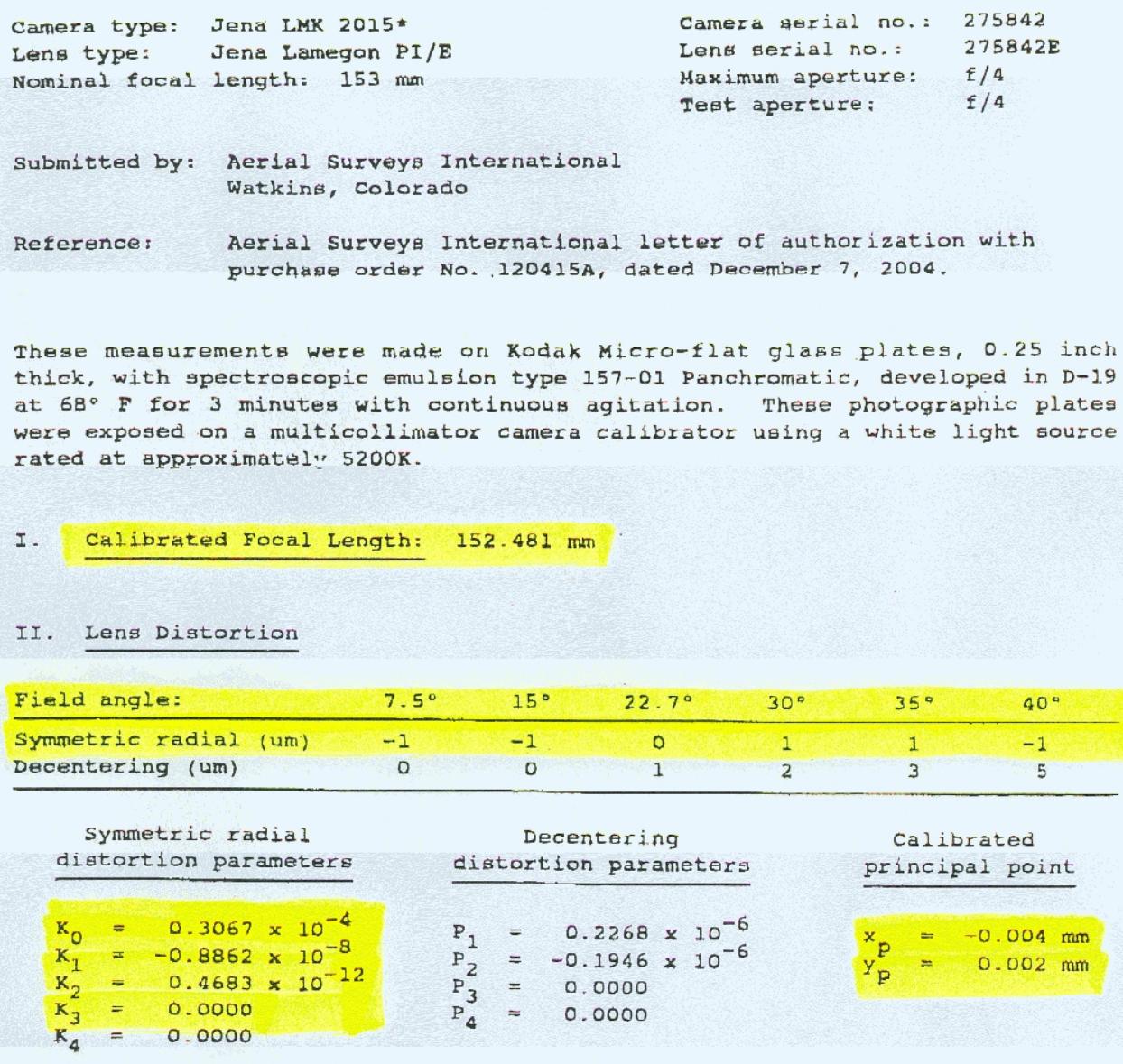

The values and parameters for Calibrated focal Length (CFL), Symmetric Radial Diatortion $\left(K_{0}, K_{1}, K_{2}, K_{3}, K_{4}\right)$, Decentering Distortion $\left(P_{1}, P_{2}, P_{3}, P_{4}\right)$, and Calibrated Principal point [point of symmetry] ( $x_{p}, y_{p}$ ) were determined through a least-squares Simultaneous Multiframe Analytical Calibration (SMAc) adjustment. The $x$ and $y$-coordinate measurements utilized in the adjustment of the above parameters have a standard deviation $(a)$ of \pm 3 microns.

* Equipped with Forward Motion Compensation 
VII. Principal Points and Fiducial coordinates

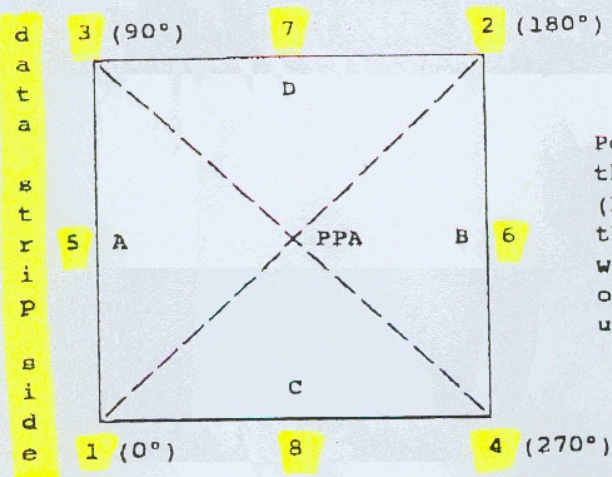

Indicated principal point, corner fiduciala Indicated principal point, midside fiducials Principal point of autocollimation (PPA) Positions of all points are referenced to the principal point of autocollimation (PPA) as origin. The diagram indicates the orientation of the reference points when the camera is viewed from the back, or a contact positive with the emulsion up. The data otrip is to the left. Calibrated principal point (pt. of sym.) $x_{p} y_{p}$

$\begin{array}{cc}X \text { coordinate } & Y \text { coordinate } \\ 0.015 \mathrm{~mm} & -0.005 \mathrm{~mm} \\ 0.013 & -0.004 \\ 0.0 & 0.0 \\ -0.004 & 0.002\end{array}$

Fiduelal Marks

$\begin{array}{rrr}1 & -109.986 \mathrm{~mm} & -110.006 \mathrm{~mm} \\ 2 & 210.017 & 109.996 \\ 3 & -109.984 & 109.990 \\ 4 & 110.019 & -110.006 \\ 5 & -111.990 & -0.006 \\ 6 & 112.025 & -0.001 \\ 7 & 0.012 & 111.990 \\ 8 & 0.014 & -112.000\end{array}$

VIII. Distances Between Fiducial Markg

Corner fiducials (diagonale) 1-2: $311.131 \mathrm{~mm} \quad 3-4: 311.127 \mathrm{~mm}$

Lines joining these markerg intergect at an angle of $90^{\circ} 00^{\circ} 04^{\prime \prime}$

Midside fiducials

5-6: $224.015 \mathrm{~mm} \quad 7-8 ; 223.990 \mathrm{~mm}$

Iines joining these markers intersect at an angle of $89^{\circ} 59^{\circ} 57^{\prime \prime}$

Corner fiducials (perimeter)

$1-3: 219.997 \mathrm{~mm} \quad 2-3: 220.001 \mathrm{~mm}$

1-4: $220.006 \mathrm{~mm} \quad 2-4: 220.003 \mathrm{~mm}$

The method of measuring these distances is considered accurate within $0.003 \mathrm{~mm}$ 
Placement of fiducials in relation to the data strip.

\begin{tabular}{l|lll|}
\cline { 2 - 4 } & 3 & 7 & 2 \\
$\mathrm{D}$ & & & \\
$\mathrm{A}$ & & & \\
$\mathrm{T}$ & & & \\
$\mathrm{A}$ & & & \\
& & & \\
& & & \\
$\mathrm{S}$ & & & \\
$\mathrm{T}$ & & & \\
$\mathrm{R}$ & & & \\
$\mathrm{I}$ & & & \\
$\mathrm{P}$ & & & \\
\hline
\end{tabular}


Control Point Placement Guide for Orthorectification of Aerial Photographs.

Control point placement guide for orthorectification of 9" $\mathrm{X}$ " aerial photographs. Use approximate $1 / 6^{\text {th }}$ divisions. Requires a minimum of 1 control point in each of the 13 areas. Control points must be as close to the fiducials as is possible.
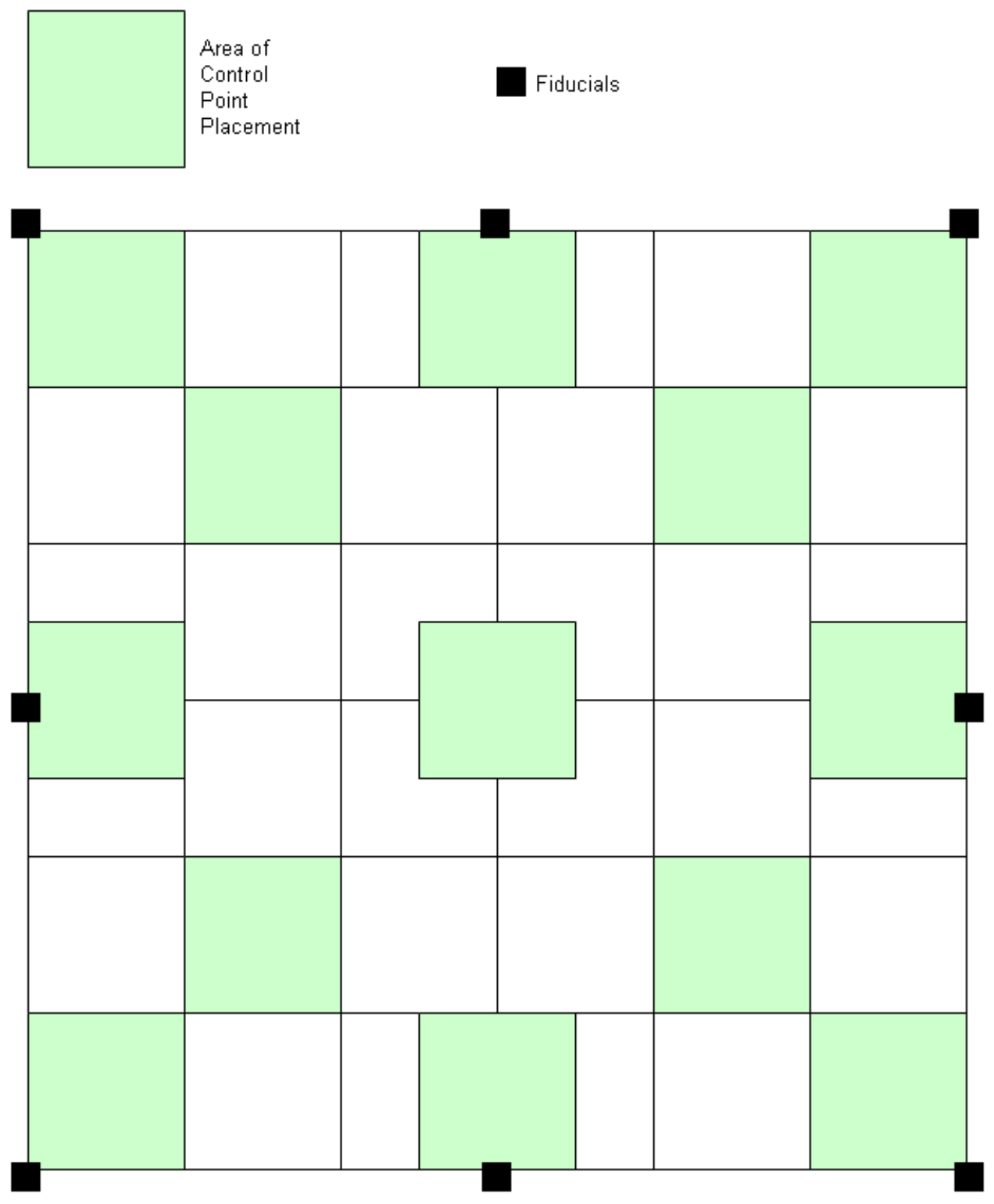


\section{Control Point Placement Guide for Orthorectification of Placement of Tie Points (orange triangles).}

Tie points are located in the magenta boxes only if there are adjacent strips of aerial photography (one side or both sides). Tie points in the green boxes tie together adjacent aerial photos along the flight path. Tie points must be located in a line perpendicular to the direction of the airplane's flight path (green boxes) and parallel to adjacent flight paths (magenta boxes). One point must be located in the ends of each box that overlap adjacent aerial photos (two points per box). A tie point is any sharp, well-defined point and is located only on the aerial photo, not on the orthophoto. A tie point can even be the corner edge of a farm field.

NOTE: The data strip is on the left side of the scanned aerial photo, and the airplane flight path was from left to right.

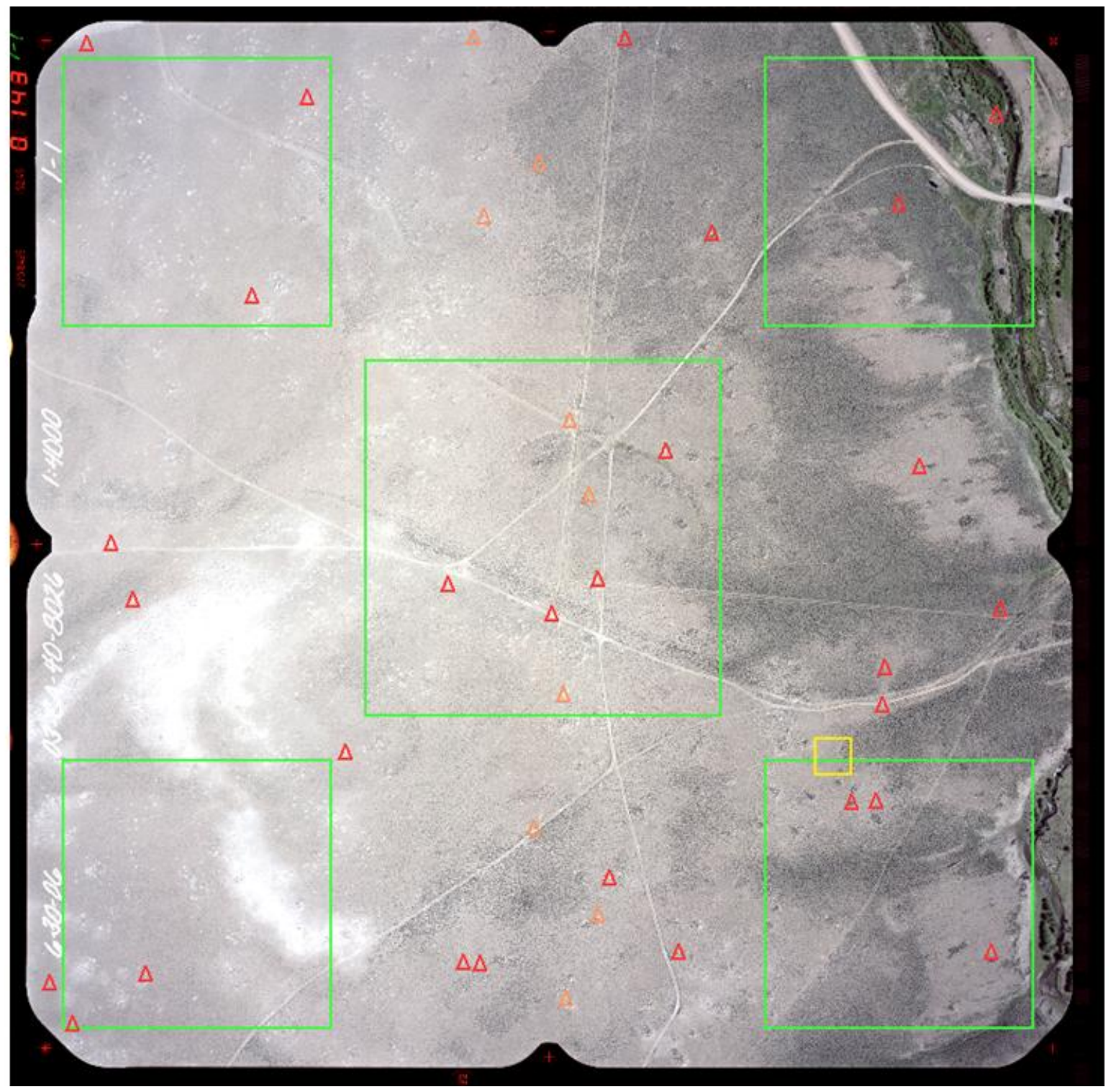


Alternative to SOP for Orthorectification form.

\author{
Digital Data Entry Facility \\ GIS and Remote Sensing Team \\ USGS Fort Collins Science Center \\ February 27, 2007
}

Date:

Data Entry Specialist:

Orthorectification Software and Version:

Project:

Aerial photo roll:

Aerial photo exposure:

Reference DOQ source:

Statement of problem:

Why the standard operating procedures should be altered:

The proposed alternative methodology:

Data Entry Specialist:

Date:

DDEF Manager Approved:

Date: 


\section{Appendix 3. Photo Orthorectification: Bundle Adjustment, Color Balance, Mosaicking}

This appendix documents the procedures used in the OrthoMapper software to perform orthorectification, color/tone balancing, and mosaicking for the Mormon Pioneer National Historic Trails Project.

One hundred and sixty-one aerial photographs were required to map the extent of this project. The orthorectification bundle adjustment was performed on groups of aerial photographs resulting in ten "flights" numbered 1, 2, 4-5, 6, 7, 9, 16, 17, 18, and 20. Individual orthorectified aerial photographs were mosaicked into 18 groups. The number of groups were later reduced to 17 (called "sections") because one group proved to be redundant.

1. Open OrthoMapper, Project, Open an Existing Project, and click on Orientation, Automated Aerotriangulation.

2. Open the project file (.PJ) for the first image in the selection to be orthorectified and Open.

3. Click the Add Images/Projects button and add the additional .LAN files to be orthorectified.

4. Enter the Project Name without a path (Flight\#). The output files will go in the working directory where the files to be orthorectified are stored. Make sure the appropriate DEM(s) is selected and click on Next.

5. Enter the number of strips, and the number of images in each strip, even if it is one strip, which it will be for this project. Then click on "Next Strip".

6. OrthoMapper will transfer the tie points. This will take some time. When it is finished, Notepad will open the file ProjectName_PPOVERLAP.log. This file is not as important as the AutoOrient Log. Open the AutoOrient Log by clicking on the Display button next to that name. The AutoOrient Log lists the common Control Points. There must be 6 to 10 points matched along a strip and 3 to 6 points between strips. If there are insufficient control points, it will be necessary to return to the individual image project and add tie points. This appears to be misleading because the points may be present but not associated properly with the overlapping images. In the next step, "Density Points", the tie points can be associated with the overlapping images.

NOTE: All tie points must be on or very close to the ground level. For example, do not use the top of a sign for a tie point because the relative position of the top of the sign will change with the movement of the airplane as consecutive aerial photographs are acquired.

7. Click on the Densify Pts button to adjust tie points to locate them in the same position on each aerial photo where they exist. Move each tie point as necessary to locate it at the same location in each image (work through each aerial photo listed under the heading: Other images on which point may be located). After adjusting all images for a given point, click on Next Point. Continue until all the necessary tie points have been adjusted. If the tie point on the source image (on left) is moved, the corresponding tie points also must be moved for every image in the list under the heading: Other images on which point may be located. After moving a tie point in the source image (on left) the other image probably will have to be adjusted for color by clicking on Enhance, Linear Stretch LUT. It may be necessary to adjust both types of tie points: those that are Out of Range and those that are not Out of Range.

After adjusting each tie point click on Save Project because OrthoMapper will lock up and fail after adjusting a number of points. The project being saved is ProjectName.PJ.

8. After the last tie point is adjusted, the windows disappear and the user is returned to the AutoOrient Examine Dialog Box. Under the Bundle Adjustment heading turn off (no check in a box) Automatically delete Tie and Control Points that have large residuals.

Turn on (place a check mark in the box), Run Initial adjustment without weights, Display progress after each adjustment, and Create Full Log File.

Then click RUN. 
NOTE: If OrthoMapper locks or exits, click on Orientation, Bundle Adjustment and Open the project ProjectName.PJ. DO NOT CLICK ON ORIENTATION, AUTOMATED AEROTRIANGULATION or it will be necessary to re-adjust all the tie points!!

9. The Bundle Adjustment Weight Menu will appear. Adjust Photo Coordinates Uncertainty until the ChiSquare Test values (Standard Deviation of Unit Weight) are between The Limits for Test. Enter new values for Uncertainty and click on the Adjust Parameters button.

If the SD needs to be increased, decrease the variables.

If the SD needs to be reduced, increase the variables.

When the ChiSquare Test is passed, click on the Make Orthophoto button.

10. After clicking on the Make Orthophoto button, the Image/DEM Selection for Orthophoto window will appear. Turn off all options except turn on Produce Single Orthophotos from list. Click Next.

11. After clicking Next the Select Output Parameters for Orthophoto window will appear. Turn on only the options to Create orthophoto(s) with minimal border pixels and Use All Bands. DO NOT turn on Radiometric Correction/Normalize. The color correction and mosaicing are done after the images are subset to remove the outer black border, fiducials, and text on the image (see next step).

\section{Click on Create Ortho(s).}

The output TIFF file can only be 4GB in size. If it is larger, a LAN file will be built instead but the LAN file is a modified ERDAS LAN file and cannot be used in ERDAS. Create sections for the output files so that they are smaller than 4GB.

Import the TIFF file into ERDAS Imagine. Use ERDAS Imagine to assign the map projection and datum to the .img file.

12. Use ArcCatalog to assign the map projection (UTM Zone 12 North) and the datum (NAD83) to the imagery.

13. Click on Trim/Subset/ReSize Image or DEM, Trim Orthophoto before Mosaicking. A four-corner polygon will appear over the image. Adjust the four corners to eliminate the outer black border, fiducials, and text on the image.

14. If the subset files are large files (Mormon Pioneer National Historic Trails files were 300+ MB), move them to the host PC instead of completing the remaining steps over the network. The color correction in particular may not run over the network. The files to move are FileName_ORTHO_SUB.TIF and FileName_ORTHO_SUB.TFW.

15. Perform the color correction. Click on Utilities, Correct Image Color/Contrast, Color Balance a Block of Images/ Tiles. The Color Balance/Blend Menu will appear. Add the Image Names to be color balanced and choose the Name of the image to standardize the colors.

Minimum Value to be used during the calculations: 25 for all bands.

Turn On:

Use Brightness of Standardized Image as block average.

Normalize Radiometric Variance.

Include standardized image in normalization process.

Click on the OK button.

16. Mosaic the color corrected images. Click on Utilities/Orthophoto Mosaic Functions/Automatically Create Orthophoto Mosaic. The Automatic Mosaic Dialog Box opens. Add the images to mosaic. DO NOT click on Color Balance because this already has been done. Provide an output mosaic file name.

The Automatic Mosaic Dialog Box appears with new options. Click on Do NOT color/tone balance the mosaic. Click on OK to produce the mosaic.

17. ERDAS Imagine was used to convert the TIFF files to the ERDAS Imagine format (.img), projection and datum information was assigned to each output file using ESRI ArcCatalog, and the files then were ready for further processing. 
Orthorectified and Mosaicked Product for Flight 1.

Flight 1 is composed of 13 orthorectified aerial photographs.

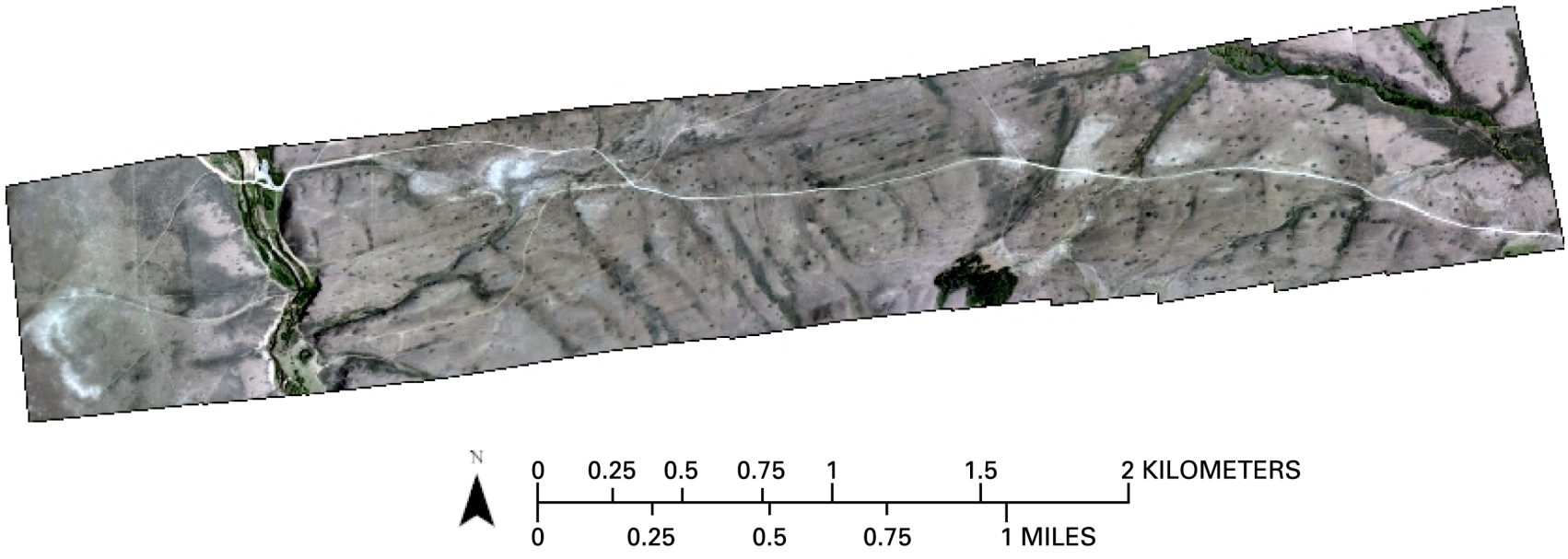

Example of Level of Detail in the Digital Orthophotos.

Part of Flight 9 digital orthophotos. Note the people walking on a high-trekker-use part of the Mormon Pioneer National Historic Trail. The part shown is part of the one-half-day, 1-day, and 2-day trek routes.

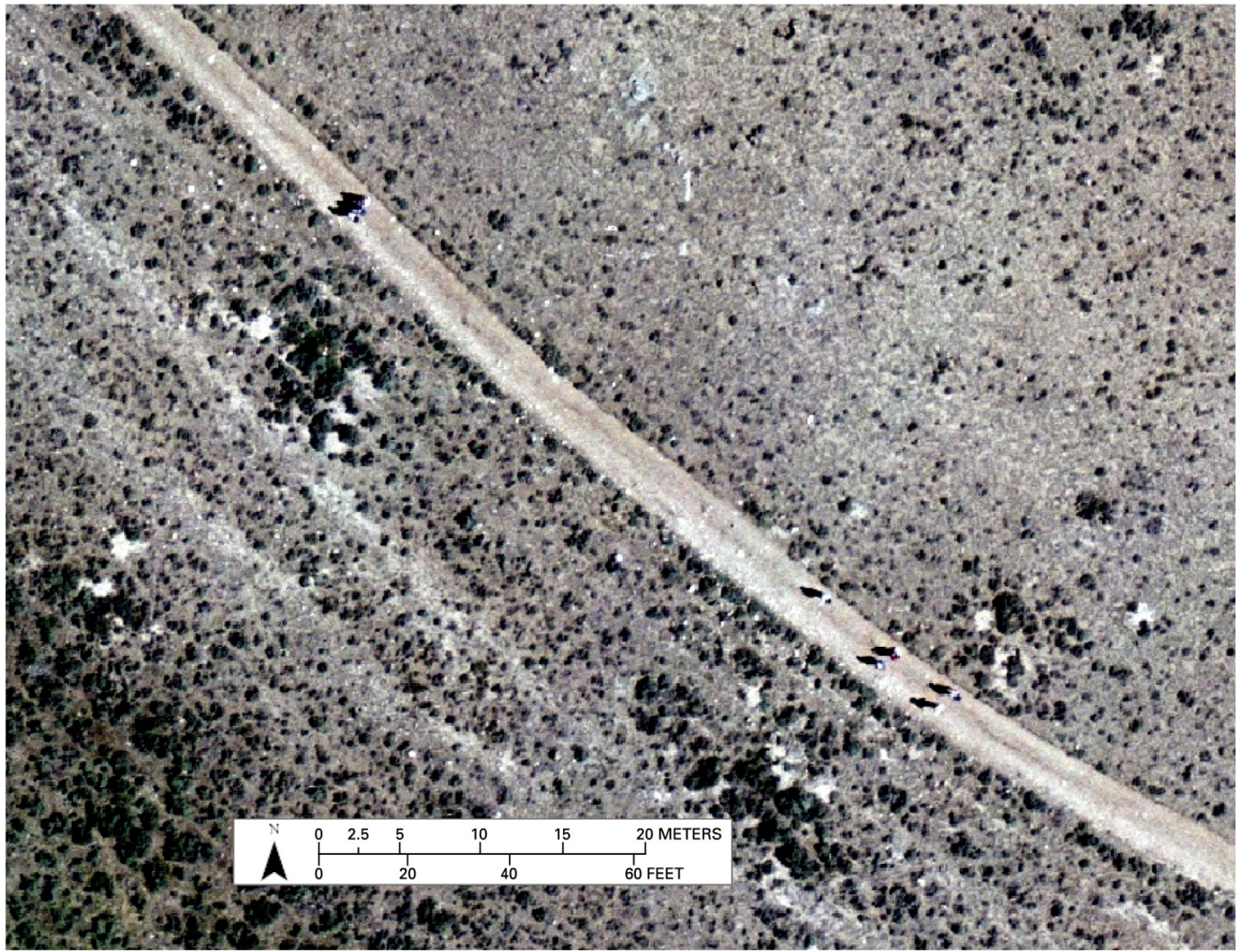




\section{Appendix 4. Delineation of the Trail and Trekker-Use Areas}

Mosaicked orthophotos for Flight 1 showing the digitized trail/road arcs (yellow), and the digitized arcs buffered to a distance of 110 meters to define the study area (red).
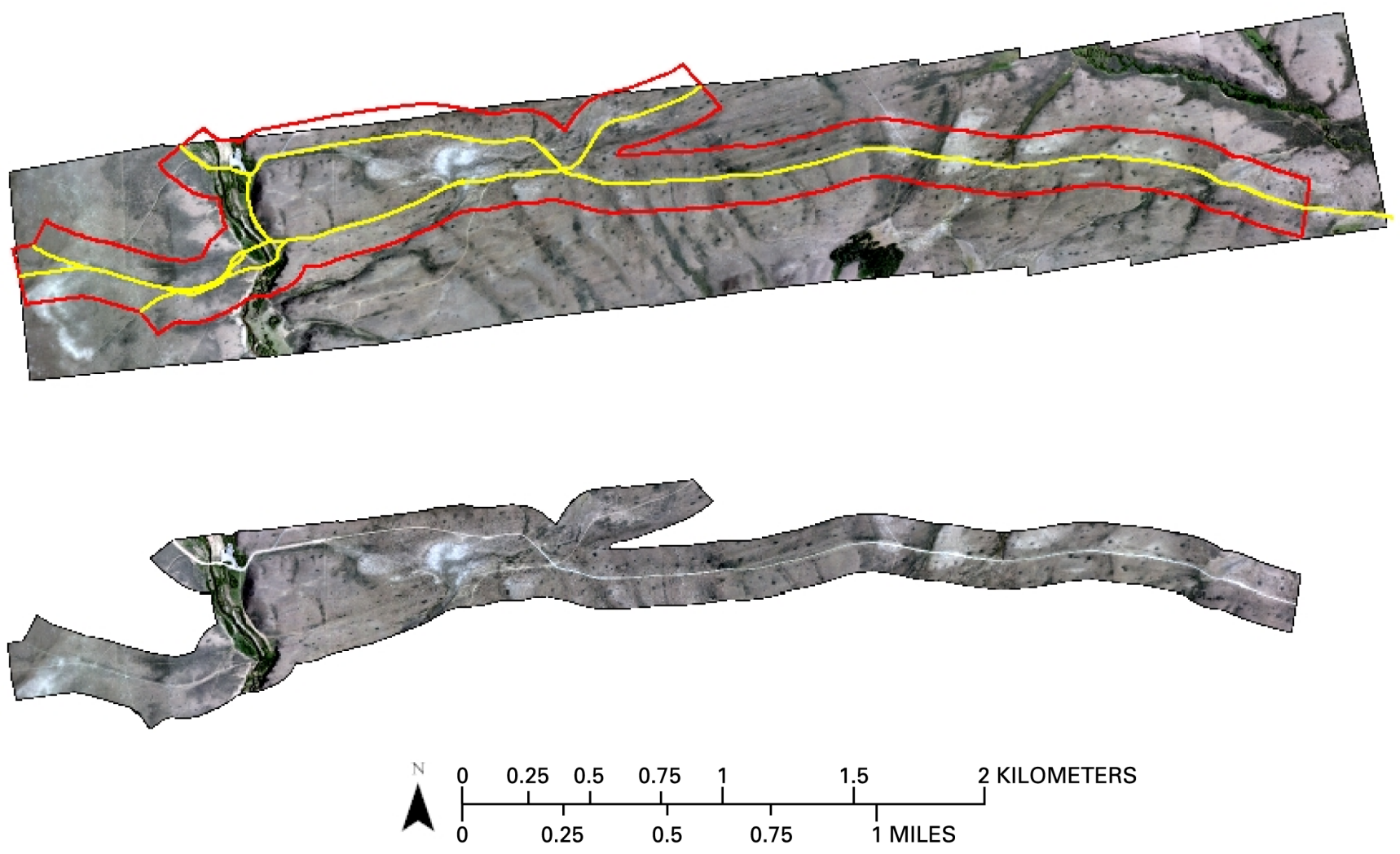

When the digital orthophoto mosaics were completed, the arcs for the Mormon Pioneer National Historic Trail and access roads and trails, were digitized on-screen at a scale of approximately 1:330. The buffered region (top, red) was used to subset the imagery to create the Section 1 imagery (below). The Rock Creek parking area is in the upper-left part of the imagery. 
The digital GIS data files for the Mormon Pioneer National Historic Trails Project include the following.

\section{Vector Files (ArcInfo Coverages):}

Polygon files defining the SECTIONS used in this study

Section 1

Section2

Section3a

Section $3 b$

Section4

Section5

Section6

Section7

Section8

Section9

Section10

Section11

Section12

Section13a

Section $13 b$

Section14

Section 15

Section 16

Section17

Historic Trail and road data (attributed)

Trlhist330

Historic Trail and road data buffered to 110 meters and divided into the SECTION files listed above Trlhist330b

\section{Orthorectified Imagery by SECTION (ERDAS Imagine format files)}

Orthorectified imagery by SECTION File Size $(M B)$

Section1.img

Section2.img

Section3a.img

Section3b.img

Section4.img

Section5.img

Section6.img

Section7.img

Section8.img

Section9.img

Section10.img

Section11.img

Section12.img

Section13a.img

Section13b.img

Section14.img

Section15.img

Section16.img

Section17.img
1645

84

335

1452

$\begin{array}{rr} & 1645 \\ & 84 \\ 1452 & \\ & \\ & 619 \\ & 538 \\ & 41 \\ & 1140 \\ & 641 \\ & 1379 \\ 686 & \\ 519 & \\ 1761 & \\ 321 & \\ 657 & \\ 195 & \\ 378 & \\ 835 & \\ 637 & \end{array}$


Bare-Ground files

Section1c60recode.img

Section2c60recode.img

Section3ac60recode.img

Section3bc60recode.img

Section4c60recode.img

Section5c60recode.img

Section6c60recode.img

Section7c60recode.img

Section8c60recode.img

Section9c60recode.img

Section10c60recode.img

Section11c60recode.img

Section12c60recode.img

Section13ac60recode.img

Section13bc60recode.img

Section14c60recode.img

Section15c60recode.img

Section16c60recode.img

Section17c60recode.img
File Size $(M B)$

549

28

112

484

206

179

13

380

214

460

229

173

587

107

219

65

126

278

212

NOTE: All digital files are in the Universal Transverse Mercator (UTM) projection, Zone 12 North, using the North American Datum of 1983 (NAD83).

NOTE: ERDAS Imagine format files can be read directly into ArcInfo, ArcGIS, and ArcView. 


\section{Appendix 5. Classification of Imagery to Bare-Ground Estimates}

The 19 sections of imagery composing the extent of the Mormon Pioneer National Historic Trails for this project were processed in ERDAS Imagine to produce a bare-ground estimate. The Iterative Self-Organizing Data Analysis Technique (ISODATA) was run on each of the 19 sections with the following specifications to produce 60 classes:

\begin{tabular}{|c|c|}
\hline $\begin{array}{l}\text { Input Raster File (.img): } \\
\quad \text { Where \# is the section de }\end{array}$ & ignation \\
\hline $\begin{array}{l}\text { Output Cluster Layer (.img): } \\
\text { Where c60 indicates ISO }\end{array}$ & $\begin{array}{l}\text { isodata\#c } 60 . i m g \\
\text { ATA will produce } 60 \text { output classes }\end{array}$ \\
\hline Output Signature Set (.sig): & isodata\#c60.sig \\
\hline Initialize from Statistics: & On \\
\hline Use Signature Means: & Off \\
\hline Number of Classes: & 60 \\
\hline Initializing Options: & $\begin{array}{l}\text { Principal axis } \\
\text { Standard deviations }=1\end{array}$ \\
\hline Color Scheme Options: & Approximate true color \\
\hline Maximum Iterations: & 300 \\
\hline Convergence Threshold: & 0.99 \\
\hline Skip Factors: & $1 \times 1$ \\
\hline Classify zeros: & Off \\
\hline
\end{tabular}

The resulting signature files (isodata\#c60.sig) were examined, and for each of the 19 sections there were breaks in the signatures that appeared to separate the categories of moderate and high likelihood of bare ground, and a set of classes defined as "all other."

The signatures created by ISODATA were applied using a Maximum Likelihood classifier to create the same number of classes but refine the spectral classification. The Maximum Likelihood output files (section\#c60ml.img) were recoded to create classes of high (value $=1$ ) and moderate (value $=2$ ) likelihood of bare ground, and an "all other" (value $=0$ ) class. The recoded files were exported to the ArcInfo GIRD format for further processing. 
Signature Mean Plot based on the imagery for Section 1. The signatures for the three image bands (red, green, blue) are plotted showing the high (red) and moderate (yellow) likelihood of bare ground. The "all other" class signatures are also displayed (black).

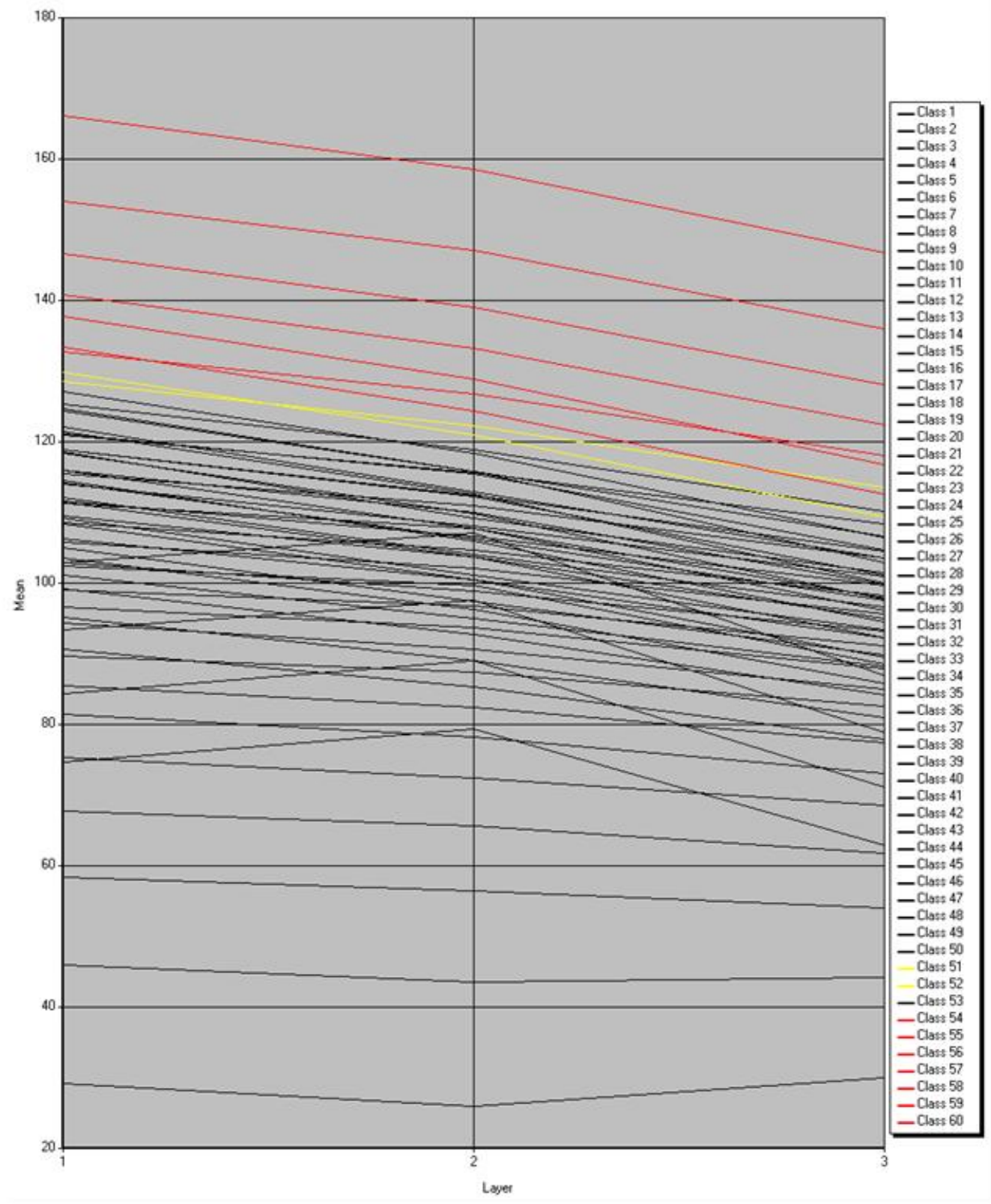


Upper Monument area of the Trail. Orthorectified true-color aerial photography (top panel) and same area showing estimated areas of high (red) and moderate (yellow) likelihood of bare ground (bottom panel)

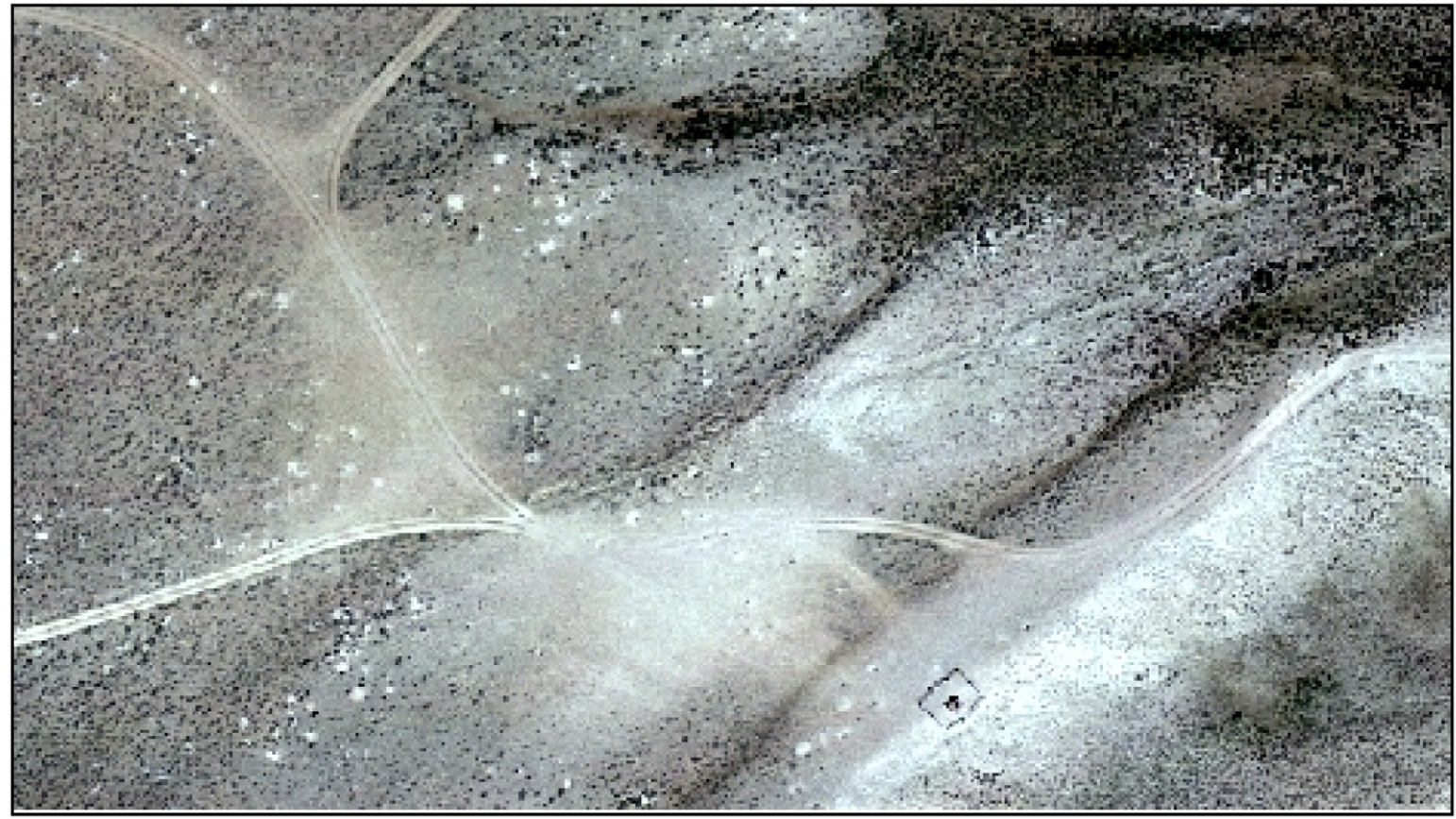

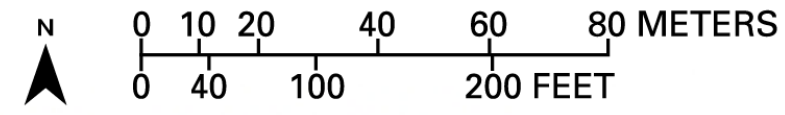

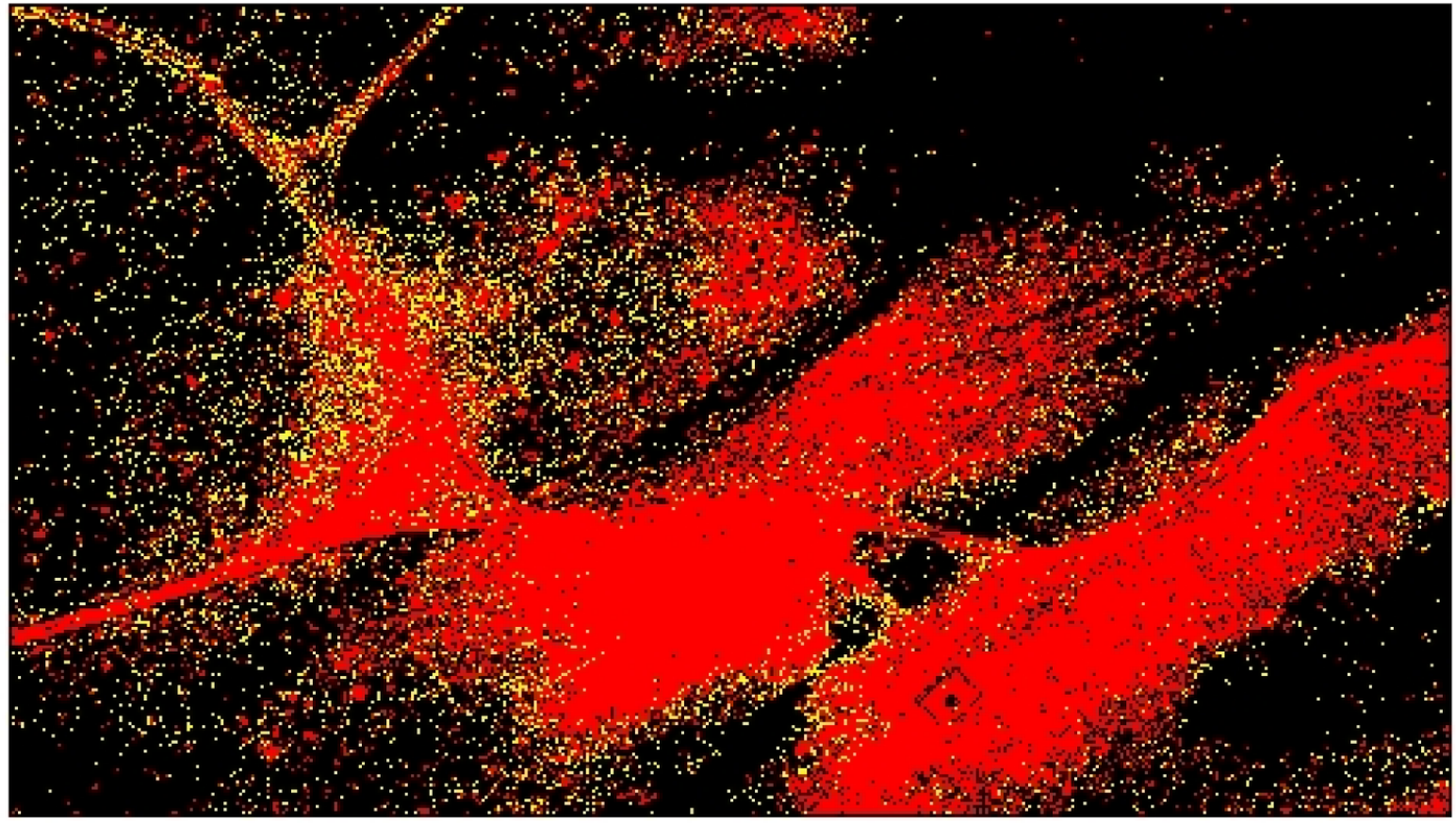


Record of Processing Steps to Create the Bare-Ground Estimates.

Mormon Pioneer National Historic Trails Recode Table

Bare-Ground Estimate

Data from June 2006

Input:

isodata\#c60ml.img Where \# is the section number, and "ml" shows the Maximum Likelihood Classifier was applied.

Output:

section\#c60recode.img Where 60 indicates ISODATA was run with 60 classes.

\begin{tabular}{|c|c|c|c|c|c|c|c|}
\hline Section & ISODATA & $\begin{array}{l}\text { Maximum } \\
\text { likelihood }\end{array}$ & $\begin{array}{c}\text { Recode } \\
\text { Class } 1 \\
\text { highest } \\
\text { likelihood } \\
\text { of bare ground }\end{array}$ & $\begin{array}{c}\text { Recode } \\
\text { Class } 2 \\
\text { lowest } \\
\text { likelihood } \\
\text { of bare } \\
\text { ground }\end{array}$ & $\begin{array}{c}\text { Output } \\
\text { file } \\
\text { name }\end{array}$ & & Image status \\
\hline 1 & isodata1c60.img & section1c60ml.img & $54-60$ & 51,52 & section1c60recode.img & $\mathrm{OK}$ & \\
\hline 2 & isodata2c60.img & section $2 \mathrm{c} 60 \mathrm{ml} .1 \mathrm{mg}$ & $55-60$ & 52,54 & section2c60recode.img & OK & \\
\hline $3 a$ & isodata3ac60.img & section3ac60ml.img & $54-60$ & 51,53 & section3ac60recode.img & OK & \\
\hline $3 b$ & isodata3bc60.img & section3bc60ml.img & $55-60$ & $53-54$ & section3bc60recode.img & OK & \\
\hline 4 & isodata $4 \mathrm{c} 60 . \mathrm{img}$ & section $4 \mathrm{c} 60 \mathrm{ml}$.img & $55-60$ & $50,52-54$ & section4c60recode.img & OK & \\
\hline 5 & isodata5c60.img & section $5 \mathrm{c} 60 \mathrm{ml}$.img & $54-60$ & $51-53$ & section5c60recode.img & OK & \\
\hline 6 & isodata6c60.img & section6c60ml.img & $54-60$ & 51,53 & section6c60recode.img & OK & Photo effects between 6 and 7 . \\
\hline 7 & isodata7c60.img & section7c60ml.img & $51-60$ & $49-50$ & section7c60recode.img & OK & \\
\hline 8 & isodata8c60.img & section8c60ml.img & $53-60$ & $51-52$ & section8c60recode.img & OK & \\
\hline 9 & isodata9c60.img & section9c60ml.img & $52-60$ & $49-51$ & section9c60recode.img & OK & \\
\hline 10 & isodata10c60.img & section10c60ml.img & $50-60$ & $47-49$ & section10c60recode.img & OK & \\
\hline 11 & isodata11c60.img & section $11 \mathrm{c} 60 \mathrm{ml} .1 \mathrm{mg}$ & $52-53,55-60$ & $49,51,54$ & section11c60recode.img & OK & \\
\hline 12 & isodata12c60.img & section $12 \mathrm{c} 60 \mathrm{ml} . i \mathrm{mg}$ & $55-60$ & 53,54 & section12c60recode.img & OK & Photo effects between 12 and 13. \\
\hline $13 \mathrm{a}$ & isodata13ac60.img & section13ac60ml.img & $54-60$ & $50-53$ & section13ac60recode.img & Photo effects & \\
\hline $13 b$ & isodata $13 \mathrm{bc} 60 . \mathrm{img}$ & section $13 \mathrm{bc} 60 \mathrm{ml} . \mathrm{img}$ & $55-60$ & 53,54 & section13bc60recode.img & Photo effects & Photo effects between 13 and 14 . \\
\hline 14 & isodata14c60.img & section14c60ml.img & $55-60$ & $52-54$ & section14c60recode.img & Photo effects & Photo effects between 14 and 15 . \\
\hline 15 & isodata15c60.img & section15c60ml.img & $55-60$ & $51-54$ & section15c60recode.img & OK & \\
\hline 16 & isodata16c60.img & section $16 \mathrm{c} 60 \mathrm{ml} . \mathrm{img}$ & $55,57-60$ & 54,56 & section16c60recode.img & Photo effects & Photo effects between 16 and 17 . \\
\hline \multirow[t]{2}{*}{17} & isodata17c60.img & section17c60ml.img & $49-60$ & 47,48 & section17c60recode.img & Photo effects & \\
\hline & & & $\begin{array}{c}\text { Value } \\
\text { assigned } \\
\text { Class } 1 \\
1\end{array}$ & $\begin{array}{c}\begin{array}{c}\text { Value } \\
\text { assigned } \\
\text { Class } 2 \\
2\end{array}\end{array}$ & $\begin{array}{c}\text { Value } \\
\text { assigned } \\
\text { background } \\
0\end{array}$ & & \\
\hline
\end{tabular}


Appendix 6. Details of Datasets and Statistical Analyses 
Description of ancillary variables considered in models describing the presence of bare soil along the Mormon Pioneer National Historic Trail.

\begin{tabular}{|c|c|c|c|c|c|c|c|c|}
\hline $\begin{array}{c}\text { Variable } \\
\text { group }\end{array}$ & Variable name & $\begin{array}{c}\text { Variable } \\
\text { code }\end{array}$ & $\begin{array}{c}\text { Variable } \\
\text { type }\end{array}$ & $\begin{array}{c}\text { Number } \\
\text { of } \\
\text { categories }\end{array}$ & Units & $\begin{array}{l}\text { Resolution } \\
\text { (meters) }\end{array}$ & $\begin{array}{l}\text { Minimum } \\
\text { value }\end{array}$ & Maximum value \\
\hline \multicolumn{9}{|c|}{ Environment-soils } \\
\hline & percentage of clay & aveclayt & continuous & 1 & percent & 27 & 0 & 22.2 \\
\hline & percentage of sand & avesandt & continuous & 1 & percent & 27 & 0 & 71.7 \\
\hline & percentage of silt & avesiltt & continuous & 1 & percent & 27 & 0 & 39.6 \\
\hline & Soil order & taxord & categorical & 7 & categories & 27 & 0 (absent) & 1 (present) \\
\hline & Soil taxonomic group & taxclnm & categorical & 23 & categories & 27 & 0 (absent) & 1 (present) \\
\hline \multicolumn{9}{|c|}{ Environment- terrain } \\
\hline & elevation & elev & continuous & 1 & meters & 27 & 1,999 & 2,248 \\
\hline & slope & slope & continuous & 1 & degrees & 27 & 0 & 24 \\
\hline & solar radiation-May 15 - Sept 15 & solar & continuous & 1 & $\mathrm{wH} / \mathrm{m} 2$ & 27 & 719,209 & 831,151 \\
\hline & compound topographic index & cti & continuous & 1 & index value & 27 & 4.1 & 23.2 \\
\hline & terrain ruggedness index & tri & continuous & 1 & index value & 27 & 0 & 30.5 \\
\hline & topographic position & topo $3 \mathrm{cls}$ & categorical & 4 & categories & 27 & 0 (absent) & 1 (present) \\
\hline & slope length factor 1 & slf1 & continuous & 1 & index value & 27 & 0 & 16.7 \\
\hline & slope length factor 2 & slf 2 & continuous & 1 & index value & 27 & 0 & 268.9 \\
\hline \multicolumn{9}{|c|}{ Trail density } \\
\hline & $10-\mathrm{m}$ radius trail density & ld10a & continuous & 1 & meters & 1 & 0 & 78.3 \\
\hline & $25-m$ radius trail density & $\operatorname{ld} 25 \mathrm{a}$ & continuous & 1 & meters & 1 & 0 & 239 \\
\hline & $50-\mathrm{m}$ radius trail density & ld50a & continuous & 1 & meters & 1 & 0 & 475.5 \\
\hline & $100-\mathrm{m}$ radius trail density & ld100a & continuous & 1 & meters & 1 & 0 & $1,075.1$ \\
\hline \multicolumn{9}{|c|}{ Photo-imagery } \\
\hline & classification (bare soil) segment & $\begin{array}{c}\text { subsec- } \\
\text { tion }\end{array}$ & categorical & 17 & categories & 0.1 & 0 (absent) & 1 (present) \\
\hline
\end{tabular}


Description of univariate analyses (log-likelihood ratio chi squares (LR $\chi^{2}$, degrees of freedom (df), $\mathbf{p}$-values, deviance, and rank) of the presence of bare soil on the Mormon Pioneer National Historic Trail (1-meter distance) using ancillary variables.

\begin{tabular}{|c|c|c|c|c|c|c|c|}
\hline $\begin{array}{l}\text { Variable } \\
\text { group }\end{array}$ & Variable name & $\operatorname{LR} \chi^{2}$ & $d f$ & $p$-value & $\begin{array}{c}\text { Percentage } \\
\text { of deviance } \\
\text { explained }\end{array}$ & $\begin{array}{c}\text { Rank within } \\
\text { group }\end{array}$ & $\begin{array}{c}\text { Overall } \\
\text { rank }\end{array}$ \\
\hline \multicolumn{8}{|c|}{ Environment- soils } \\
\hline & percentage of clay & 0.97 & 1 & 0.325 & 0.1 & 5 & 15 \\
\hline & percentage of sand & 13.76 & 1 & $<0.001$ & 0.8 & 3 & 10 \\
\hline & percentage of silt & 7.81 & 1 & 0.005 & 0.5 & 4 & 11 \\
\hline & Soil order & 59.96 & 6 & $<0.001$ & 4.8 & 2 & 4 \\
\hline & Soil taxonomic name & 184.99 & 20 & $<0.001$ & 14.2 & 1 & 2 \\
\hline \multicolumn{8}{|c|}{ Environment-terrain } \\
\hline & elevation & 46.97 & 1 & $<0.001$ & 3.6 & 1 & 5 \\
\hline & slope & 2.44 & 1 & 0.118 & 0.1 & 5 & 14 \\
\hline & solar radiation (May 15 - Sept 15 ) & 29.87 & 1 & $<0.001$ & 1.9 & 2 & 7 \\
\hline & compound topographic index & 0.00 & 1 & 0.982 & 0.0 & 6 & 16 \\
\hline & terrain ruggedness index & 0.80 & 1 & 0.370 & 0.0 & 6 & 16 \\
\hline & topographic position & 16.64 & 3 & $<0.001$ & 1.1 & 3 & 9 \\
\hline & slope length factor 1 & 4.77 & 1 & 0.029 & 0.3 & 4 & 13 \\
\hline & slope length factor 2 & 0.04 & 1 & 0.844 & 0.0 & 6 & 16 \\
\hline \multicolumn{8}{|c|}{ Trail density } \\
\hline & 10 meter radius trail density & 6.05 & 1 & 0.014 & 0.4 & 4 & 12 \\
\hline & 25 meter radius trail density & 22.27 & 1 & $<0.001$ & 1.5 & 3 & 8 \\
\hline & 50 meter radius trail density & 43.35 & 1 & $<0.001$ & 3.0 & 2 & 6 \\
\hline & 100 meter radius trail density & 73.88 & 1 & $<0.001$ & 5.6 & 1 & 3 \\
\hline \multicolumn{8}{|c|}{ Photo-imagery } \\
\hline & classification (bare soil) segment & 200.54 & 16 & $<0.001$ & 17.9 & 1 & 1 \\
\hline
\end{tabular}


Category groupings for soils and subsection of trail (photo-image) to reduce analysis degrees of freedom.

\begin{tabular}{cccccccc}
$\begin{array}{l}\text { Variable } \\
\text { group }\end{array}$ & Variable name & LR $\chi^{2}$ & $d f$ & p-value & $\begin{array}{c}\text { Percentage } \\
\text { of deviance } \\
\text { explained }\end{array}$ & $\begin{array}{c}\text { Rank } \\
\text { within } \\
\text { group }\end{array}$ & $\begin{array}{c}\text { Overall } \\
\text { rank }\end{array}$ \\
\hline
\end{tabular}

Environment- soils

percentage of clay

percentage of sand

percentage of silt

Soil order

Soil taxonomic name

0.97

13.76

7.81

59.96

162.75

Environment- terrain

elevation
slope
solar radiation (May 15 - Sept 15)
compound topographic index
terrain ruggedness index
topographic position
slope length factor 1
slope length factor 2

Trail density

10 meter radius trail density

25 meter radius trail density

50 meter radius trail density

100 meter radius trail density

22.27

73.88

46.97
2.44
29.87
0.00
0.80
16.64
4.77
0.04

0.325
$<0.001$
0.005
$<0.001$
$<0.001$

0.1

0.8

0.5

4.8

13.0

$<0.001$

3.6

0.1

0.118

19

$<0.001$

0.982

0.370

0.0

$<0.001$

0.029

0.844

0.0

1.1

0.3

0.0

0.014

0.4

$<0.001$

1.5

$<0.001$

3.0

$<0.001$

5.6

$\begin{array}{rr}5 & 15 \\ 3 & 10 \\ 4 & 11 \\ 2 & 4 \\ 1 & 2\end{array}$

Photo-imagery 


\begin{tabular}{|c|c|c|c|c|c|}
\hline $\begin{array}{c}\text { Soil } \\
\text { number }\end{array}$ & Soil taxonomic class description & Group 1 & Group 2 & Group 3 & Group 4 \\
\hline 3 & Coarse-loamy, mixed, superactive Borollic Haplargids-Fine-loamy, mixed, superactive Borollic Natrargids & $\mathrm{X}$ & & & \\
\hline 4 & $\begin{array}{l}\text { Coarse-loamy, mixed, superactive, calcareous, frigid Ustic Torriorthents-Loamy, mixed, superactive, calcareous, frigid, shal- } \\
\text { low Ustic Torriorthents }\end{array}$ & & $\mathrm{X}$ & & \\
\hline 5 & Coarse-loamy, mixed, superactive, calcareous, frigid Aquic Ustifluvents-Fine, montmorillonitic Borollic Natrargids & $\mathrm{X}$ & & & \\
\hline 7 & $\begin{array}{l}\text { Coarse-loamy, mixed, superactive, calcareous, frigid Ustic Torriorthents-Loamy-skeletal, mixed, superactive, calcareous, } \\
\text { frigid, shallow Ustic Torriorthents }\end{array}$ & $\mathrm{X}$ & & & \\
\hline 11 & $\begin{array}{l}\text { Coarse-loamy, mixed, superactive, frigid Ustic Haplargids-Fine-loamy over sandy or sandy-skeletal, mixed, superactive, } \\
\text { frigid Ustic Calciargids }\end{array}$ & & & $\mathrm{X}$ & \\
\hline 13 & $\begin{array}{l}\text { Fine-loamy over sandy or sandy-skeletal, mixed, superactive Borollic Haplargids-Loamy-skeletal, mixed, superactive, cal- } \\
\text { careous, frigid, shallow Ustic Torriorthents }\end{array}$ & & & $\mathrm{X}$ & \\
\hline 15 & Loamy-skeletal, mixed, superactive Lithic Cryoborolls-Loamy-skeletal, mixed, superactive Lithic Cryoborolls & $\mathrm{X}$ & & & \\
\hline 17 & Fine-loamy, mixed, superactive Argic Cryoborolls-Loamy-skeletal, mixed, superactive Argic Cryoborolls & & & & $\mathrm{X}$ \\
\hline 18 & Fine-loamy, mixed, superactive Argic Cryoborolls-Fine-loamy, mixed, superactive Typic Cryoborolls & & $\mathrm{X}$ & & \\
\hline 19 & Loamy-skeletal, mixed, superactive Lithic Cryoborolls-Loamy-skeletal, mixed, superactive Typic Cryoborolls & & & & $\mathrm{X}$ \\
\hline 20 & Fine-loamy, mixed, superactive Borollic Haplargids-Fine-loamy, mixed, superactive, frigid Ustic Haplargids & & & $\mathrm{X}$ & \\
\hline 21 & Fine-loamy, mixed, superactive, frigid Ustic Calciargids-Fine-loamy, mixed, superactive, frigid Ustic Calciargids & & & $\mathrm{X}$ & \\
\hline 22 & Coarse-loamy, mixed, superactive Typic Cryaquolls-Fine-loamy, mixed, superactive Cumulic Haplocryolls & & $X$ & & \\
\hline 24 & $\begin{array}{l}\text { Loamy, mixed, superactive, calcareous, frigid, shallow Ustic Torriorthents-Loamy, mixed, superactive, calcareous, frigid, } \\
\text { shallow Ustic Torriorthents }\end{array}$ & $\mathrm{X}$ & & & \\
\hline 25 & Loamy-skeletal, carbonatic, frigid Lithic Calciustepts-Loamy-skeletal, carbonatic, frigid Lithic Calciustepts & & & & $X$ \\
\hline 26 & Coarse-loamy, mixed, superactive Cumulic Cryaquolls-Fine-loamy, mixed, superactive Typic Cryoborolls & $\mathrm{X}$ & & & \\
\hline 27 & Loamy-skeletal, carbonatic, frigid Aridic Calciustepts-Loamy-skeletal, carbonatic, frigid Lithic Calciustepts & & & & $\mathrm{X}$ \\
\hline
\end{tabular}


Identification of the grouping of soil taxonomic classes (categories) for subsequent analyses of bare soil.—Continued

\section{Soil}

number

Soil taxonomic class description

Fine, montmorillonitic Borollic Natrargids-Fine-loamy, mixed, superactive Argic Cryoborolls

29 Fine-loamy, mixed, superactive Argic Cryoborolls-Loamy-skeletal, mixed, superactive Argic Lithic Cryoborolls

30 Fine, smectitic, frigid Leptic Torrertic Natrustalfs-Fine-loamy, mixed, superactive, frigid Ustic Haplargids

Coarse-loamy, mixed, superactive, calcareous, frigid Aquic Ustifluvents-Fine-loamy, mixed, superactive, calcareous, frigid Aeric Fluvaquents
Group 1

Group 2

Group 3

Group 4

X

X

X 


\begin{tabular}{|c|c|c|c|c|c|}
\hline $\begin{array}{c}\text { Subsection } \\
\text { number }\end{array}$ & Group 1 & Group 2 & Group 3 & Group 4 & Group 5 \\
\hline $3 a$ & & $\mathrm{X}$ & & & \\
\hline $3 b$ & $\mathrm{X}$ & & & & \\
\hline 4 & $\mathrm{X}$ & & & & \\
\hline 5 & & & & & $\mathrm{X}$ \\
\hline 6 & & & & & $\mathrm{X}$ \\
\hline 7 & & & & & $\mathrm{X}$ \\
\hline 8 & $\mathrm{X}$ & & & & \\
\hline 9 & & & & $\mathrm{X}$ & \\
\hline 10 & $\mathrm{X}$ & & & & \\
\hline 11 & & & & $\mathrm{X}$ & \\
\hline 12 & & & $\mathrm{X}$ & & \\
\hline $13 a$ & & $\mathrm{X}$ & & & \\
\hline $13 b$ & & & $\mathrm{X}$ & & \\
\hline 14 & & & & $\mathrm{X}$ & \\
\hline 15 & $\mathrm{X}$ & & & & \\
\hline 16 & & & $\mathrm{X}$ & & \\
\hline 17 & & & & & $\mathrm{X}$ \\
\hline
\end{tabular}


Predicted probability of bare ground (equivalent to proportion bare ground) by photo-image and soil group, handcart-use categories, and trail location ( $\mathrm{m}$, meters).

\begin{tabular}{|c|c|c|c|c|c|c|c|c|c|c|c|}
\hline \multirow{2}{*}{$\begin{array}{l}\text { Photo- } \\
\text { Image* }^{*}\end{array}$} & \multirow{2}{*}{ Soils* } & \multicolumn{2}{|c|}{ No carts, nonmotorized } & \multicolumn{2}{|c|}{ No carts, motorized } & \multicolumn{2}{|c|}{ Low cart use } & \multicolumn{2}{|c|}{ Moderate cart use } & \multicolumn{2}{|c|}{ High cart use } \\
\hline & & $0 \mathrm{~m}$ & $1 \mathrm{~m}$ & $0 \mathrm{~m}$ & $1 \mathrm{~m}$ & $\mathbf{O m}$ & $1 \mathrm{~m}$ & $0 \mathrm{~m}$ & $1 \mathrm{~m}$ & $0 \mathrm{~m}$ & $1 \mathrm{~m}$ \\
\hline 1 & 1 & 0.351 & 0.692 & 0.668 & 0.948 & 0.753 & 0.936 & 0.659 & 0.974 & 0.695 & 0.959 \\
\hline 1 & 2 & 0.134 & 0.075 & 0.366 & 0.398 & 0.467 & 0.347 & 0.357 & 0.575 & 0.395 & 0.457 \\
\hline 1 & 3 & 0.282 & 0.392 & 0.594 & 0.840 & 0.689 & 0.808 & 0.584 & 0.915 & 0.623 & 0.870 \\
\hline 1 & 4 & 0.377 & 0.363 & 0.692 & 0.822 & 0.773 & 0.788 & 0.683 & 0.904 & 0.718 & 0.855 \\
\hline 2 & 1 & 0.093 & 0.326 & 0.275 & 0.797 & 0.365 & 0.759 & 0.267 & 0.889 & 0.301 & 0.833 \\
\hline 2 & 2 & 0.028 & 0.017 & 0.098 & 0.125 & 0.142 & 0.102 & 0.095 & 0.226 & 0.110 & 0.153 \\
\hline 2 & 3 & 0.069 & 0.122 & 0.216 & 0.530 & 0.295 & 0.475 & 0.209 & 0.698 & 0.238 & 0.590 \\
\hline 2 & 4 & 0.102 & 0.109 & 0.298 & 0.499 & 0.391 & 0.444 & 0.289 & 0.671 & 0.324 & 0.559 \\
\hline 3 & 1 & 0.283 & 0.550 & 0.595 & 0.908 & 0.690 & 0.888 & 0.585 & 0.953 & 0.624 & 0.926 \\
\hline 3 & 2 & 0.102 & 0.042 & 0.296 & 0.265 & 0.389 & 0.224 & 0.288 & 0.424 & 0.323 & 0.314 \\
\hline 3 & 3 & 0.223 & 0.260 & 0.516 & 0.741 & 0.618 & 0.696 & 0.506 & 0.854 & 0.547 & 0.784 \\
\hline 3 & 4 & 0.306 & 0.237 & 0.621 & 0.716 & 0.713 & 0.669 & 0.611 & 0.837 & 0.650 & 0.762 \\
\hline 4 & 1 & 0.391 & 0.662 & 0.704 & 0.941 & 0.783 & 0.927 & 0.696 & 0.970 & 0.729 & 0.953 \\
\hline 4 & 2 & 0.155 & 0.067 & 0.406 & 0.367 & 0.509 & 0.317 & 0.396 & 0.542 & 0.436 & 0.424 \\
\hline 4 & 3 & 0.318 & 0.361 & 0.634 & 0.821 & 0.724 & 0.786 & 0.624 & 0.904 & 0.662 & 0.854 \\
\hline 4 & 4 & 0.417 & 0.333 & 0.727 & 0.802 & 0.801 & 0.764 & 0.719 & 0.892 & 0.751 & 0.837 \\
\hline 5 & 1 & 0.539 & 0.736 & 0.813 & 0.958 & 0.868 & 0.948 & 0.807 & 0.979 & 0.831 & 0.966 \\
\hline 5 & 2 & 0.251 & 0.092 & 0.555 & 0.451 & 0.654 & 0.397 & 0.545 & 0.627 & 0.586 & 0.511 \\
\hline 5 & 3 & 0.460 & 0.445 & 0.760 & 0.867 & 0.827 & 0.839 & 0.752 & 0.930 & 0.782 & 0.892 \\
\hline 5 & 4 & 0.567 & 0.414 & 0.829 & 0.852 & 0.880 & 0.822 & 0.824 & 0.922 & 0.846 & 0.880 \\
\hline
\end{tabular}


Location, size, and percentage of bare ground summarized for all nine concentrated impact areas (locations are given as Universal Transverse Mercator (UTM) coordinates).

\begin{tabular}{|c|c|c|c|c|c|}
\hline ID & Disturbance type & UTM Easting & UTM Northing & $\begin{array}{c}\text { Area } \\
\left(\text { meters }^{2}\right)\end{array}$ & $\begin{array}{l}\text { Bare ground } \\
\text { (percent) }\end{array}$ \\
\hline 1 & portable toilet use, vehicles parking, trampling, livestock & 704240.19 & 4702546.33 & $1,774.73$ & 29.83 \\
\hline 2 & portable toilet use, trampling, handcarts pulled off trail & 709663.47 & 4703264.36 & $3,054.77$ & 33.53 \\
\hline 3 & vehicles parking, turning around & 710361.70 & 4704045.79 & 751.44 & 82.37 \\
\hline 4 & trampling, dispersal of trekkers & 710510.85 & 4704196.63 & $2,599.53$ & 66.93 \\
\hline 5 & trampling, handcarts off trail & 710689.25 & 4704317.95 & $3,757.79$ & 56.54 \\
\hline 6 & trampling & 711824.33 & 4704545.80 & 45.71 & 27.19 \\
\hline 7 & trampling & 712552.97 & 4704867.43 & 466.51 & 13.89 \\
\hline 8 & vehicles parking, trampling & 712886.39 & 4705348.47 & $7,237.29$ & 67.01 \\
\hline \multirow[t]{3}{*}{9} & vehicles parking, portable toilet use, trampling & 726718.28 & 4711223.40 & $1,496.52$ & 27.76 \\
\hline & Mean & & & $2,353.81$ & 45.01 \\
\hline & Standard deviation & & & $2,205.06$ & 23.56 \\
\hline
\end{tabular}


Publishing support provided by: Denver Publishing Service Center

Manuscript approved for publication, June 17, 2008

Edited by Mary A. Kidd

Graphics and layout by Sharon Powers

For more information concerning this publication, contact:

Team Chief Scientist, USGS Crustal Imaging and Characterization

Box 25046, Mail Stop 964

Denver, CO 80225

(303) 236-1312

Or visit the Crustal Imaging and Characterization Team Web site at: http://crustal.usgs.gov/ 


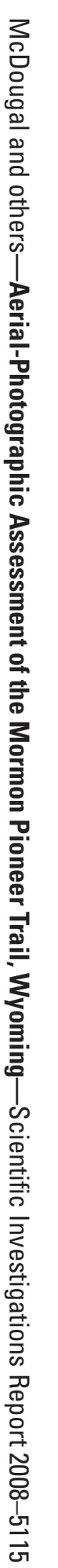

